\title{
The Paleoproterozoic Nattanen-type granites in northern Finland and vicinity - a postcollisional oxidized A-type suite
}

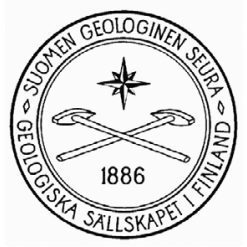

\author{
Esa Heilimo ${ }^{1)^{*}}$, Jaana Halla ${ }^{2)}$, Laura S. Lauri ${ }^{1)}$, O. Tapani Rämö ${ }^{\mathrm{T}}$, \\ Hannu Huhma ${ }^{3}$, Matti I. Kurhila ${ }^{\mathrm{I})}$, and Kai Front ${ }^{4)}$ \\ 1) Department of Geology, P.O. Box 64, FI-00014 University of Helsinki, Finland \\ 2) Geological Museum, Finnish Museum of Natural History, P.O. Box 11, FI-00014 University \\ of Helsinki, Finland \\ 3) Geological Survey of Finland, P.O. Box 96, FI-02151 Espoo, Finland \\ 4) VTT, P.O.Box 1000, Espoo, FI-02044 VTT, Finland
}

\begin{abstract}
The $~ 1.8 \mathrm{Ga}$ Nattanen-type granites in the Finnish Lapland and western Kola Peninsula are found as several relatively small, high-level, discordant plutons that are easily discernible as weak maxima on aeromagnetic maps. We present $\mathrm{U}-\mathrm{Pb}$ mineral isotope data on the Finnish plutons. The concordia ages are in the 1.79-1.77 Ga range and there is little evidence for inheritance. Initial radiogenic isotope compositions (our common-Pb data combined with previously published whole-rock $\mathrm{Nd}$ and $\mathrm{Hf}$ data) imply a major, yet varying, Archean source component. Elemental geochemical data on five Finnish intrusions (the Nattanen stock, the Tepasto and Pomovaara complexes, the Riestovaara and Vainospää batholiths), as well as, associated dyke rocks allow the Nattanen-type granites to be classified as oxidized A-type granites. Their petrogenesis may be related to partial melting of the lower crust by mafic underplating (extensional setting) or as a result of thermal relaxation in thickened crustal setting.
\end{abstract}

Key words: granites, A-type granites, geochemistry, genesis, absolute age, isotopes, U/Pb, $\mathrm{Pb} / \mathrm{Pb}$, Paleoproterozoic, Lapland Province, Finland.

* Corresponding author email: esa.heilimo@helsinki.fi

\section{Introduction}

Since their recognition in the 1920's (Mikkola, 1928), the Nattanen-type granites in northern Finland and adjacent Russia have remained a rare example of highly discordant, post-orogenic, high-level granite plutons in the far north of the Fennoscandian shield. These plutons (the Nattanen stock, the Tepasto and Pomovaara complexes, the Riestovaara and Vainospää batholiths on the Finnish side; the Juvoaivi stock and the Litsa-Aragub complexes on the Russian side) are younger ( $1.77-1.80 \mathrm{Ga}$; Kouvo et al., 1983; Meriläinen, 1976, Vetrin et al., 2006; this study) than their immediate country rocks and are found as multiple intrusions within the Neoarchean and early Paleoproterozoic metamorphic bedrock of Finnish Lapland and vicinity. The Nattanen-type granites are characterized by miarolitic cavities, evolved com- 
positions, and an oxidized redox budget (titanite and magnetite as conspicuous minor phases) (Haapala et al., 1987; Front et al., 1989; Lehtiö, 1993). They are also associated with evolved rhyolitic dyke rocks and minor Mo-mineralization. Geochemically, the Nattanen-type granites have previously been considered mainly I-type, but some of the more evolved intrusive phases of the plutons may show A- or S-type characteristics (Front et al., 1989). Available isotope data (Lu-Hf, Sm-Nd, $\mathrm{Pb}-\mathrm{Pb}$ ) imply a major Archean source component for these granites (Patchett et al., 1981; Kouvo et al., 1983; Huhma, 1986). In this paper we present whole-rock and $\mathrm{K}$-feldspar $\mathrm{Pb}-\mathrm{Pb}$ as well as zircon, monazite, and titanite $\mathrm{U}-\mathrm{Pb}$ isotope data on the Nattanen-type intrusions. We use these data to examine the temporal evolution of the granites and refine their source model. We also elaborate on existing whole-rock elemental geochemical data in order to enhance their typological significance.

\section{Geologic setting}

The northern part of the Fennoscandian shield is composed of several Archean crustal domains (Karelia, Kola, and Norrbotten, inset in Fig. 1; e.g., Lahtinen et al., 2005) and intracratonic basins of Paleoproterozoic supracrustal rocks that were intruded by several generations of mafic and felsic intrusive rocks (e.g., Hanski \& Huhma, 2005; Nironen, 2005). Extensional tectonics prevailed in the early Paleoproterozoic, fracturing the Archean Karelian craton from ca. $2.45 \mathrm{Ga}$ onwards and creating gradually deepening basins that were subsequently filled with supracrustal material (e.g., Lehtonen et al., 1998; Hanski \& Huhma, 2005). The long extensional period ended by ca. 1.93 Ga when the Karelia and Kola domains collided (the Lapland-Kola orogeny) and the Lapland granulite belt (LGB) was formed (Daly et al., 2001; Lahtinen et al., 2005 and references therein; Fig. 1). The Lapland-Kola orogeny was followed by the collision of Karelia with the Norrbotten domain (Fig. 1 inset) from the present northwest at ca. $1.92 \mathrm{Ga}$ (Lahtinen et al., op.cit.). The Karelia-Norrbotten collision thrusted the volcanic rocks of the Kittilä group on to the Karelian domain (Lehtonen et al., 1998; Hanski \& Huhma, 2005; Lahtinen et al., 2005; Patison et al., 2006). The final major accretional event was the formation of the Svecofennian domain in the south (e.g., Lahtinen et al., op. cit.).

Several granitoid-forming events (most of them collisional) have been recognized in the northern part of the Fennoscandian shield (e.g., Nironen, 2005 and references therein). However, the oldest known Paleoproterozoic granites of ca. 2.1 Ga age cannot be connected to any presently known collision (Huhma, 1986; Rastas et al., 2001; Ahtonen et al., 2007). Granitoids with ages in the 1.95-1.91 Ga range (and classified as preorogenic by Nironen, 2005) are known within the Hetta complex (Fig. 1; Rastas et al., 2001) as well as intruding the Kittilä group (Huhma, 1986; Rastas et al., 2001; Ahtonen et al., 2007), the Lapland granulite belt (LGB; Tuisku \& Huhma, 2006), and in the Inari complex (Meriläinen, 1976). Synorogenic, ca. 1.89-1.86 Ga granitoids intruded the older rock types mostly in Sweden and western Lapland, and they are coeval with the Svecofennian granitoids farther south (e.g., Lehtonen et al., 1998; Bergman et al., 2001; Nironen, 2005). The last granite-forming phase occurred between $1.80 \mathrm{Ga}$ and $1.76 \mathrm{Ga}$, producing the deformed migmatites, leucogranites, and appinitic intrusions (Mutanen \& Väänänen, 2004) of the central Lapland granitoid complex (CLGC; the late-orogenic granites of Nironen, 2005; see also Ahtonen et al., 2007), as well as the discordant Nattanen-type granite plutons.

\section{The Nattanen-type granites}

The Nattanen-type plutons are found in western, central, and northern Finnish Lapland. The location of these granite plutons seems to be largely controlled by crustal-scale fracture zones and they are found in all three blocks of the Archean crust (Figs. 1 and 2). The following description of the Nattanen, Tepasto, Pomovaara, and Riestovaara intrusions is mainly based on Front et al. (1989) and concerning ore minerals it is based on Lehtiö (1993); the Vainospää granite is described after Meriläinen (1976) and the 

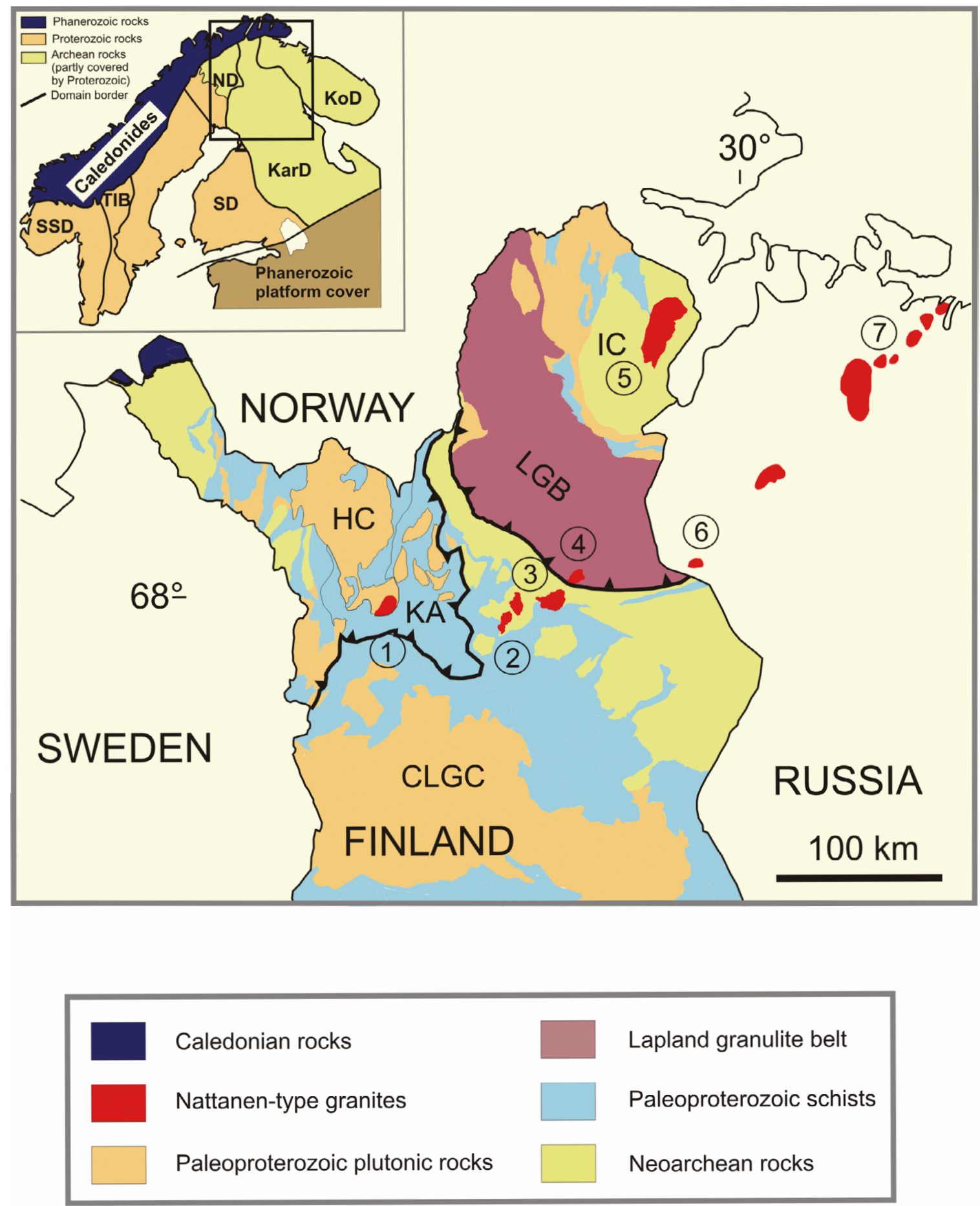

Fig. I. Geological sketch map of northern Finland showing the location of the $\sim 1.8 \mathrm{Ga}$ Nattanen-type granites in Finnish Lapland and far northwest Russia. Modified from Korsman et al. (1997), and Haapala et al. (1987). Key to the intrusions: 1 = Tepasto; 2 = Pomovaara; 3 = Riestovaara; 4 = Nattanen; 5 = Vainospää; 6 = Juvoaivi; 7 = Litsa-Aragub. Key to the crustal units: IC = Inari complex; LGB = Lapland granulite belt; KA = Kittilä allochthon; $\mathrm{HC}=$ Hetta complex; CLGC = Central Lapland granitoid complex. Inset shows the location of the area relative to the Fennoscandian shield. $\mathrm{KoD}=$ Kola domain; $\mathrm{KarD}=$ Karelian domain; $\mathrm{ND}=$ Norbotten domain; $\mathrm{SD}=$ Svecofennian domain; TIB = Transscandinavian igneous belt; SSD = Southwest Scandinavian domain. 


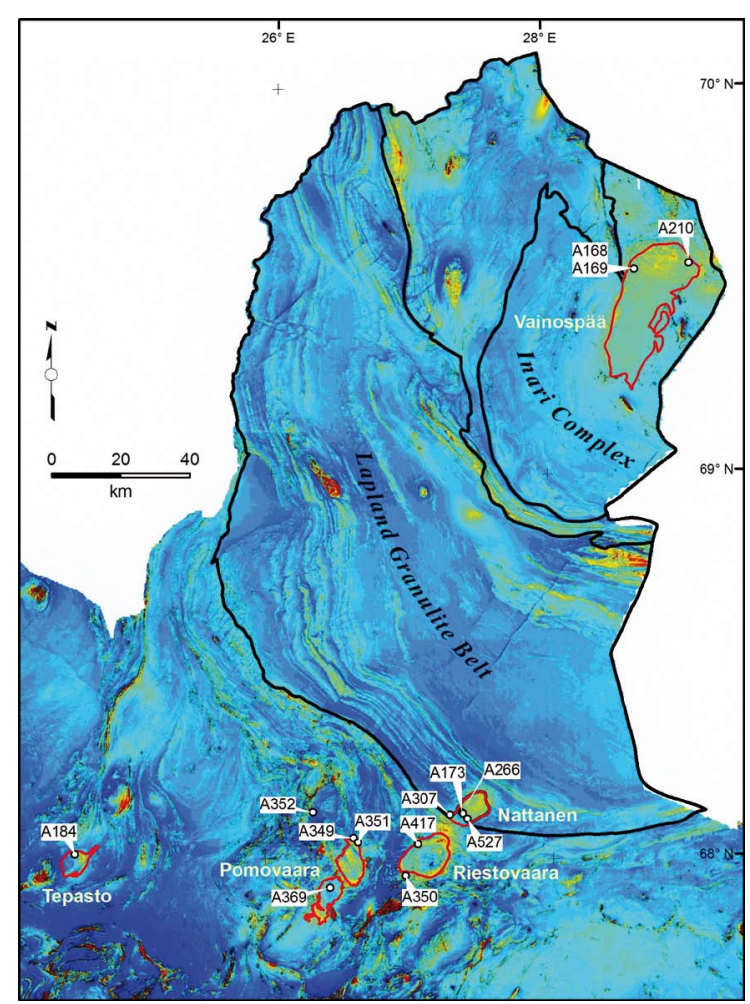

Fig. 2. Aeromagnetic map of northernmost Finland based on aeromagnetic data from the Geological Survey of Finland (GTK). The Nattanen-type granites are marked by moderate magnetic maxima. A-coded numbers denote isotope sample locations of this study.

Nattanen-type granites in Russia after Vetrin et al. (2006).

The Nattanen-type granites are typically unfoliated, medium- to coarse-grained monzogranites with allanite, zircon, and titanite as typical accessory minerals (Mikkola, 1941). The granite types of the plutons differ more in texture than in mineral composition. The main mineralogical and petrographic features of the Nattanen-type granites are summarized in Table 1.

\section{I. Nattanen stock}

The type intrusion of the Nattanen-type granites, the Nattanen stock (Fig. 3a), is mainly hosted by the LGB that is composed of alternating layers of psam- mitic to pelitic migmatites and younger, ca. 1.92$1.91 \mathrm{Ga}$ rocks of norite-enderbite series (Tuisku \& Huhma, 2006; Tuisku et al., 2006). Most of the Nattanen stock consists of coarse-grained biotite granite. Medium-grained granite is found only in the southern parts where the pluton intrudes garnet-hornblende gneisses instead of granulites. The stock is surrounded and rarely cross-cut by numerous rhyolite dykes with several textural variants from banded to spherulitic.

\subsection{Tepasto complex}

The westernmost Nattanen-type intrusion, the Tepasto complex, is hosted by Paleoproterozoic granites and migmatites of the Hetta complex that are in turn surrounded by the volcanic rocks of the Kittilä group (e.g., Lehtonen et al., 1985, 1998; Korsman et al., 1997; Pakkanen, 1993; Rastas et al., 2001). The Tepasto complex consists of several different granite types that form a concentric stock (Fig. 3b). The biotite-bearing coarse-porphyritic granite of the outer part is intruded by biotite granite in the central part of the pluton. The youngest phase is aplite granite that cross-cuts and brecciates the other granite types. Zircon U-Pb age of $1802 \pm 10 \mathrm{Ma}(\mathrm{MSWD}=7)$ was reported for the coarse-porphyritic granite of the Tepasto stock by Rastas et al. (2001). Several small Moand $\mathrm{Cu}$-occurrences have been found associated with the Tepasto complex. Most of them are in contact with the aplite granite or in small greisens near them. Ore minerals include molybdenite, bornite, covellite, chalcopyrite, hematite, pyrrhotite, magnetite, pyrite, sphalerite, ilmenite, and goethite.

\subsection{Pomovaara complex}

The Pomovaara complex in central Lapland comprises three individual stocks: Lehtovaara, Pomovaara, and Tenniövaara (Fig. 3c; Front et al., 1989; Wennerström \& Airo, 1998). The Lehtovaara stock is mainly composed of coarse-porphyritic granite and minor granite porphyry. The Pomovaara stock is a concentric multiphase pluton with biotite-bearing porphy- 
Table I. Summary of the major granite phases of the Nattanen-type granites in northern Finland, their mineralogy and main petrographic features.

\begin{tabular}{|c|c|c|c|c|}
\hline Intrusion & Intrusion phase & Petrography & Mineralogy ${ }^{1)}$ & References: \\
\hline \multirow[t]{2}{*}{$\begin{array}{l}\text { Nattanen } \\
\text { stock }\end{array}$} & $\begin{array}{l}\text { Coarse-grained } \\
\text { granite }\end{array}$ & $\begin{array}{l}\text { Unfoliated, homogeneous and coarse-grained } \\
\text { monzogranite with rapakivi texture sensu lato. }\end{array}$ & $\begin{array}{l}\text { Qtz, Kfs, Plg, Bt, } \\
\text { Op, All, Apa, Zrc, } \\
\text { Ms, Ser, Chl, Epi, Fl, } \\
\text { Mon, Ilm, Tit, Go } \\
\end{array}$ & $\begin{array}{l}\text { Luukkonen, 1989; } \\
\text { Front et al., 1989; } \\
\text { Lehtiö, } 1993\end{array}$ \\
\hline & $\begin{array}{l}\text { Medium-grained } \\
\text { granite }\end{array}$ & $\begin{array}{l}\text { Unfoliated, homogeneous with miarolitic cav- } \\
\text { ities }(\varnothing=1-2 \mathrm{~mm}) \text {. }\end{array}$ & $\begin{array}{l}\text { Kfs, Plg, Qtz, Bt, Op, } \\
\text { Zrc, Apa, All, Epi, } \\
\text { Ms, Chl } \\
\end{array}$ & \\
\hline \multirow[t]{3}{*}{$\begin{array}{l}\text { Tepasto } \\
\text { complex }\end{array}$} & $\begin{array}{l}\text { Coarse-porphyritic } \\
\text { granite }\end{array}$ & $\begin{array}{l}\text { Slightly foliated monzogranite with euhedral } \\
\text { K-feldspar, plagioclase and quartz phenoc- } \\
\text { rysts. Rapakivi texture in places. }\end{array}$ & $\begin{array}{l}\text { Kfs, Plg, Qtz, Bt, } \\
\pm \mathrm{Hbl}, \mathrm{Op}, \text { Tit, Apa, } \\
\mathrm{Zrc}, \mathrm{Fl}, \text { All, Chl, Epi, } \\
\text { Ms, Ser }\end{array}$ & Front et al., 1989 \\
\hline & Biotite granite & $\begin{array}{l}\text { Even-grained, medium-grained monzogran- } \\
\text { ite. Biotite and plagioclase are oriented along } \\
\text { a weak foliation. K-feldspar and plagiocla- } \\
\text { se show micrographic and myrmekitic inter- } \\
\text { growth textures. }\end{array}$ & $\begin{array}{l}\text { Qtz, Kfs, Plg, Bt, Epi, } \\
\text { Chl, Ser, Op, Tit, } \\
\text { Apa, Zrc, Fl }\end{array}$ & \\
\hline & Aplite granite & $\begin{array}{l}\text { Medium-grained and even-grained, homoge- } \\
\text { neous, unfoliated monzogranite with a small } \\
\text { amount of micas. Plagioclase typically shows } \\
\text { myrmekitic texture. }\end{array}$ & $\begin{array}{l}\text { Qtz, Kfs, Plg, Bt, Ms, } \\
\text { Op, Tit, Apa, Hem, } \\
\text { Epi, Ms, Chl }\end{array}$ & \\
\hline \multirow[t]{2}{*}{$\begin{array}{l}\text { Pomovaara } \\
\text { complex }\end{array}$} & Porphyritic granite & $\begin{array}{l}\text { K-feldspar and plagioclase megacrysts are } \\
\text { euhedral. K-feldspars show occasional rapa- } \\
\text { kivi-texture. Matrix is medium-grained and } \\
\text { composed of feldspars, quartz and biotite. }\end{array}$ & $\begin{array}{l}\text { Qtz, Kfs, Plg, Bt, Op, } \\
\text { Tit, Epi, All, Apa, } \\
\text { Zrc, Chl, Ms, Ser }\end{array}$ & Front et al., 1989 \\
\hline & $\begin{array}{l}\text { Two-mica and } \\
\text { biotite granites }\end{array}$ & $\begin{array}{l}\text { Monzogranites with K-feldspar and plagiocla- } \\
\text { se phenocrysts. Matrix is unfoliated and me- } \\
\text { dium-grained in both granite types. }\end{array}$ & $\begin{array}{l}\text { Qtz, Kfs, Plg, Bt } \pm \\
\text { Ms, Op, Tit, Epi, All, } \\
\text { Apa, Zrc, Chl, Ser } \\
\end{array}$ & \\
\hline \multirow[t]{3}{*}{$\begin{array}{l}\text { Riestovaara } \\
\text { batholith }\end{array}$} & $\begin{array}{l}\text { Coarse-porphyritic } \\
\text { granite }\end{array}$ & $\begin{array}{l}\text { K-feldspar and plagioclase megacrysts. K-feld- } \\
\text { spar is perthitic and plagioclase shows myrme- } \\
\text { kitic texture. Occasional rapakivi texture. }\end{array}$ & $\begin{array}{l}\text { Qtz, Kfs, Plg, Bt } \\
\pm \text { Hbl, Mgt, Tit, All, } \\
\text { Zrc, Apa, Epi, Chl, } \\
\text { Ms }\end{array}$ & Front et al., 1989 \\
\hline & Porphyritic granite & $\begin{array}{l}\text { The amount of feldspar megacrysts varies (5- } \\
20 \%) . \text { K-feldspar megacrysts are perthitic. }\end{array}$ & $\begin{array}{l}\text { Qtz, Kfs, Plg, Bt, } \\
\text { Mgt, Tit, All, Apa, } \\
\text { Zrc, Mon, Fl }\end{array}$ & \\
\hline & $\begin{array}{l}\text { Medium-grained } \\
\text { granite }\end{array}$ & $\begin{array}{l}\text { Even-grained granite with micrographic inter- } \\
\text { growths. }\end{array}$ & $\begin{array}{l}\text { Qtz, Kfs, Plg, Bt, Fl, } \\
\text { Op, Tit, Apa, Zrc, } \\
\text { All, Chl, Ms }\end{array}$ & \\
\hline $\begin{array}{l}\text { Vainospää } \\
\text { batholith }\end{array}$ & & $\begin{array}{l}\text { Slightly foliated intrusion with two granite } \\
\text { types: medium-grained, porphyritic type, and } \\
\text { coarse-grained, slightly porphyritic type. Pla- } \\
\text { gioclase is zoned and shows myrmekitic tex- } \\
\text { ture. }\end{array}$ & $\begin{array}{l}\text { Kfs, Plg, Qtz, Bt, } \\
\text { Chl, Apa, Zrc, Op, } \\
\text { Tit, Fl, All, Preh, Car }\end{array}$ & $\begin{array}{l}\text { Meriläinen, 1976; } \\
\text { This study }\end{array}$ \\
\hline
\end{tabular}

1) Accessory minerals are in italics. Mineral abbreviations: All - Allanite, Apa - Apatite, Bt - Biotite, Car - Carbonate, Chl - Chlorite, Epi - Epidote, Fl - Fluorite, Go - Goethite, Hem - Hematite, Hbl - Hornblende, Ilm - Ilmenite, Kfs - K-feldspar, Mgt - Magnetite, Mon - Monazite, Ms - Muscovite, Op - Opaque minerals, Plg - Plagioclase, Preh - Prehnite, Qtz Quartz, Ser - Sericite, Tit - Titanite, Zrc - Zircon. 

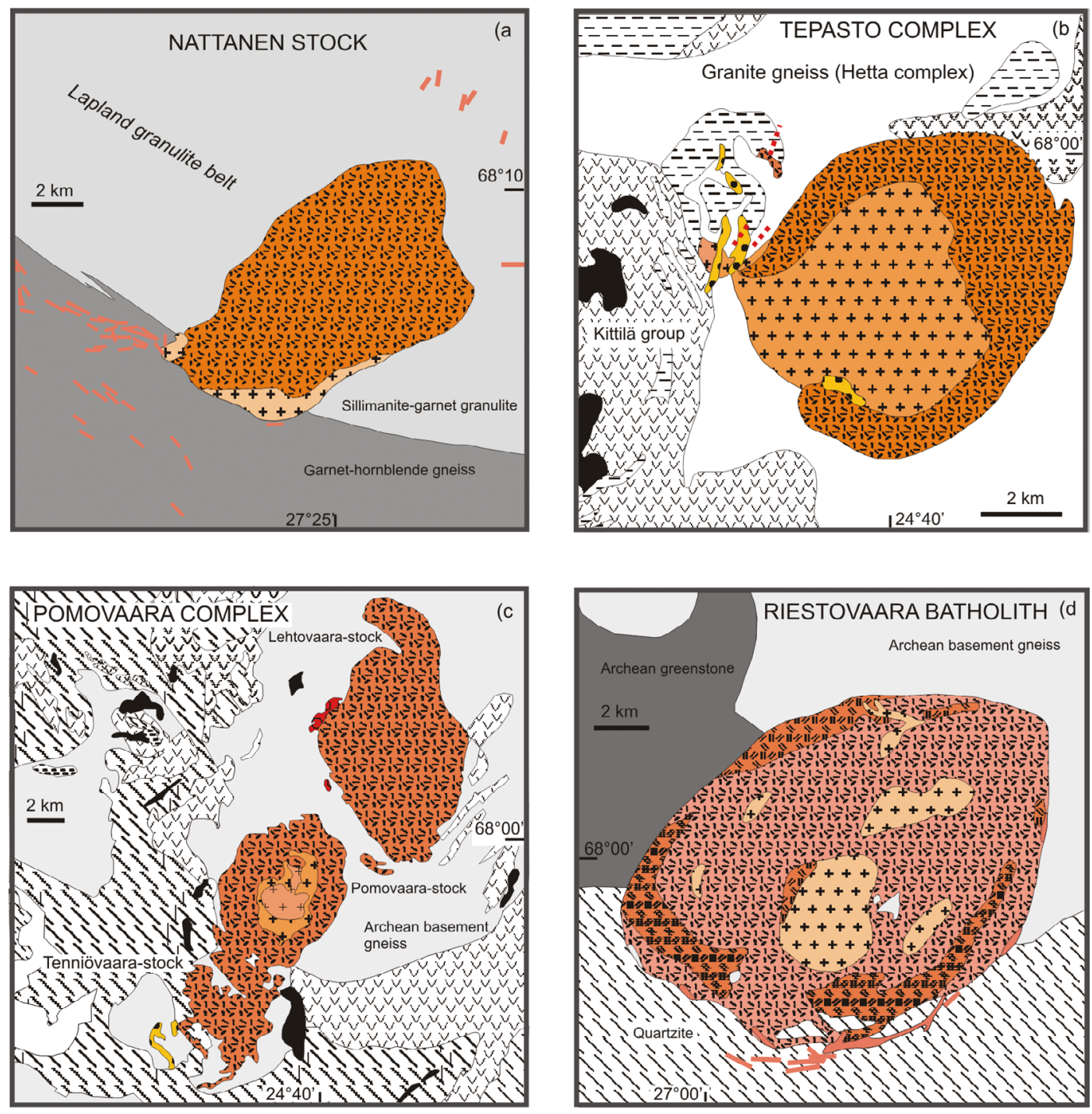

\begin{tabular}{|c|c|}
\hline NATTANEN-TYPE INTRUSIONS & Quartz-feldspar porphyry \\
\hline Coarse-grained granite & Porphyritic dyke \\
\hline fillu Coarse-porphyritic granite & Rhyolite dyke \\
\hline Porphyritic granite & Mylonite greisen \\
\hline++ Medium-grained granite & COUNTRY ROCKS \\
\hline++ Biotite granite & $\bar{E}=$ Granite \\
\hline++ Two-mica granite & Metagabbro, metaperidotite \\
\hline \multirow[t]{2}{*}{$\because \quad$ Aplite granite } & Metavolcanites \\
\hline & S Metasediments \\
\hline
\end{tabular}

Fig. 3. Lithologic maps of the a) Nattanen stock; b) Tepasto complex; c) Pomovaara complex; d) Riestovaara batholith. The Nattanen-type intrusions modified from Front et al. (1989), country rocks adapted from Lehtonen et al. (1998) and Korsman et al. (1997). 
ritic granite at the outer rim and biotite granite and two-mica granite in the central part. The Tenniövaara stock is composed of gray, porphyritic granite, which shows a weak orientation. Some porphyritic granite and aplite dykes are found outside the southern contact of the Tenniövaara stock. The Pomovaara complex is hosted by quartz-feldspar gneisses that have been considered to be Archean in age. However, the gneisses chiefly show heterogeneous Paleoproterozoic zircon populations, some of them with a rather well constrained magmatic age of ca. $2.49 \mathrm{Ga}$ (Manninen et al., 2001). Minor Mo-mineralization is found in the Pomovaara complex and is associated with aplite and pegmatite dykes, quartz veins and mylonites. Ore minerals in the Mo-occurences are molybdenite, chalcopyrite, pyrite, arsenopyrite, hematite, and goethite.

\subsection{Riestovaara batholith}

The Riestovaara batholith (Fig. 3d) is the largest Nattanen-type granite pluton on the southern side of the LGB. It is hosted by Archean granitic gneisses in the north and Paleoproterozoic quartzites, mica schists, gneisses, and metavolcanic rocks $(2454 \pm 5 \mathrm{Ma})$ in the south (Front et al., 1989; Manninen et al., 2001; Nironen \& Mänttäri, 2003). The batholith consists of three granite types. Coarse-porphyritic granite is the oldest phase and forms an incomplete rim around the pluton. Most of the Riestovaara batholith consists of porphyritic granite, which is cross-cut in the central part of the intrusion by medium-grained granite. All granite types are biotite-bearing and undeformed, but magmatic foliation is observed in some outcrops. The southern part of the Riestovaara batholith hosts some granite porphyry dykes that are also present within the host rocks. Quartz-feldspar porphyry dykes, aplite dykes, and granodioritic to quartz dioritic dykes are also found.

\subsection{Vainospää batholith}

The Vainospää batholith is the largest of the Nattanen-type plutons in Finland. The thickness of the batholith has been approximated to $6 \mathrm{~km}$ by threedimensional gravity modeling (Elo et al., 1989). The batholith is hosted by the rocks of the Archean Inari terrane, on the NE side of the LGB (Fig. 1). Meriläinen (1976) coined the intrusion the KyyneljärviVainospää granite and divided it into two sub-areas: the southern, gray Kyyneljärvi granite and the northern Vainospää granite. The latter consists of slightly foliated, pink-gray, porphyritic granite and grey, coarse-grained granite.

\subsection{Nattanen-type granites in Russia}

Several Nattanen-type granite plutons are also found in the Russian territory east of the Vainospää batholith and the Nattanen stock (Fig. 1; e.g., Vetrin et al., 1975; Vetrin et al., 2006). The small Juvoaivi stock that intrudes the rocks of the LGB on the Russian side of the border was described and included in the Nattanen-type group by Mikkola (1928). The larger Litsa-Aragub complex farther north consists of at least six intrusions covering an area of $900 \mathrm{~km}^{2}$ along a large fault zone that probably controlled their emplacement. The Juvoaivi and Litsa-Aragub granites show ages in the 1.79-1.76 Ga range (Vetrin et al., 2006). The magmatic association in the Litsa-Aragub complex forms a series from diorites to granites and leucogranites.

\section{Geochemistry}

We have compiled 115 whole-rock geochemical analyses of the Nattanen-type granites. The dataset contains 75 previously unpublished major element analyses from the Nattanen stock (Table 2), 25 major and trace element analyses from all Nattanen-type rocks from The Rock Geochemical Database of Finland (Rasilainen et al., 2007; Appendix 1), and 15 selected granite major element median compositions from Front et al. (1989; Appendix 1). Samples of aplite and rhyolite dykes from the Nattanen intrusion are also included. 
Table 2. Major element and zirconium analyses of the Nattanen stock *).

\begin{tabular}{|c|c|c|c|c|c|c|c|c|c|c|c|c|c|}
\hline Sample & $\begin{array}{c}\mathrm{SiO}_{2} \\
\text { (wt.\%) }\end{array}$ & $\mathrm{TiO}_{2}$ & $\mathrm{Al}_{2} \mathrm{O}_{3}$ & FeOt & $\mathrm{MnO}$ & $\mathrm{MgO}$ & $\mathrm{CaO}$ & $\mathrm{Na}_{2} \mathrm{O}$ & $\mathrm{K}_{2} \mathrm{O}$ & $\mathbf{P}_{2} \mathbf{O}_{5}$ & Tot & $\begin{array}{c}\mathrm{Zr} \\
(\mathrm{ppm})\end{array}$ & $\begin{array}{c}\mathrm{Ga} \\
(\mathrm{ppm})\end{array}$ \\
\hline \multicolumn{14}{|c|}{ Nattanen granite (coarse-grained) } \\
\hline $4014-1$ & 74.23 & 0.15 & 12.85 & 1.70 & 0.01 & 0.23 & 0.62 & 3.50 & 4.82 & 0.07 & 98.18 & 189 & 24 \\
\hline 4036 & 72.52 & 0.33 & 13.23 & 2.15 & 0.03 & 0.32 & 0.98 & 3.64 & 4.34 & 0.09 & 97.63 & 230 & 26 \\
\hline $4038-1$ & 72.52 & 0.27 & 13.23 & 1.71 & 0.03 & 0.27 & 0.78 & 3.50 & 4.70 & 0.07 & & 179 & 27 \\
\hline 4040 & 71.88 & 0.35 & 13.04 & 2.26 & 0.03 & 0.35 & 0.83 & 3.64 & 4.70 & 0.16 & & 259 & 27 \\
\hline 4042 & 74.02 & 0.20 & 12.85 & 1.58 & & & 0.57 & 3.64 & 4.70 & 0.05 & & 172 & 29 \\
\hline 4048 & 73.59 & 0.17 & 13.23 & & 0.03 & 0.32 & 0.74 & 3.64 & 5.06 & 0.07 & 98.80 & 218 & 25 \\
\hline $4050-1$ & 72.1 & 0.1 & 13.42 & 1.32 & 0.01 & 0.18 & 0.76 & 3.77 & 4.70 & 0.14 & 96.50 & 117 & 28 \\
\hline 4053 & 75.09 & 0.18 & 12.85 & 1.68 & 0.02 & 0.18 & 0.62 & 3.64 & 4.70 & 0.07 & 99.03 & 190 & 25 \\
\hline $4055-2$ & 73.81 & 0.18 & 13.98 & 2.22 & 0.02 & 0.36 & 0.64 & 3.50 & 4.82 & 0.09 & 99.62 & 270 & 22 \\
\hline $4057-1$ & 74.23 & 0.25 & 13.79 & 1.98 & 0.02 & 0.28 & 1.04 & 3.91 & 5.06 & 0.11 & 100.67 & 199 & 26 \\
\hline $4060-1$ & 73.16 & 0.33 & 13.60 & 2.38 & 0.04 & 0.36 & 1.11 & 3.77 & 4.94 & 0.11 & 99.80 & 269 & 27 \\
\hline $4061-1$ & 75.3 & 0.25 & 13.79 & 1.76 & 0.02 & 0.3 & 0.92 & 3.91 & 5.06 & 0.11 & 101.42 & 218 & 22 \\
\hline 4062 & 74.88 & 0.28 & 13.60 & & & & 0.92 & 3.91 & 5.06 & 0.11 & & 243 & 30 \\
\hline $4065-1$ & 74.45 & 0.23 & 13.42 & 2.08 & 0.02 & & 0.83 & 3.77 & 4.94 & 0.09 & 100.13 & 233 & 30 \\
\hline $4066-1$ & 74.02 & 0.28 & 13.60 & & & & 0.91 & 4.04 & 4.94 & 0.14 & 100.05 & 208 & 25 \\
\hline $4069-1$ & 75.09 & & 13.79 & & 0.03 & & 0.88 & 3.77 & 5.06 & 0.11 & 101.62 & 266 & 26 \\
\hline $4069-2$ & 75.52 & 0.17 & 13.23 & & 0.01 & 0.15 & 0.46 & 3.50 & 4.82 & 0.02 & 99.42 & 200 & 25 \\
\hline 4074-2 & 73.16 & & & & & & 0.73 & 3.77 & 4.70 & 0.14 & & 277 & 27 \\
\hline $4075-1$ & 75.09 & 0.25 & 13.23 & & & & 0.71 & 3.64 & 4.70 & 0.09 & & 216 & 26 \\
\hline 4079-1 & 73.16 & 0.35 & 13.98 & 2.13 & 0.03 & 0.33 & 0.99 & 3.91 & 4.58 & 0.21 & 99.67 & 218 & 25 \\
\hline $4082-1$ & 76.16 & 0.18 & 13.60 & 1.57 & 0.01 & 0.2 & 0.60 & 3.77 & 4.94 & 0.18 & 101.21 & 185 & 25 \\
\hline 4086 & 75.09 & 0.27 & 12.85 & 1.63 & 0.02 & 0.23 & 0.76 & 3.37 & 4.70 & 0.18 & 99.10 & 192 & 22 \\
\hline 4092 & 76.16 & 0.17 & 13.04 & 1.50 & 0.01 & 0.15 & 0.76 & 3.64 & 4.82 & 0.23 & 100.48 & 150 & 24 \\
\hline 4112 & 75.3 & 0.15 & 12.85 & 1.25 & 0.02 & 0.15 & 0.5 & 3.37 & 4.94 & 0.11 & 98.64 & 150 & 25 \\
\hline 4116 & 75.09 & 0.27 & 13.42 & 1.67 & 0.02 & 0.25 & 0.85 & 3.64 & 4.58 & 0.09 & 99.88 & 161 & 24 \\
\hline $4122-1 \mathrm{~A}$ & 75.73 & 0.13 & 13.79 & 1.17 & 0.01 & 0.18 & 0.74 & 3.64 & 4.70 & 0.25 & 100.34 & 109 & 22 \\
\hline 4128 & 75.09 & 0.27 & 13.79 & 1.86 & 0.02 & 0.3 & 0.74 & 3.77 & 4.58 & 0.09 & 100.51 & 215 & 26 \\
\hline $4131-1$ & 74.02 & 0.27 & 13.42 & 1.89 & 0.02 & 0.28 & 0.87 & 3.77 & 4.58 & 0.11 & 99.23 & 218 & 24 \\
\hline $4133-1$ & 74.23 & 0.33 & 13.04 & 2.25 & 0.02 & 0.33 & 0.77 & 3.64 & 4.58 & 0.11 & 99.30 & 235 & 23 \\
\hline $4222-1$ & 74.23 & 0.17 & 13.04 & 1.59 & 0.02 & 0.17 & 0.46 & 3.50 & 4.82 & 0.00 & 98.00 & 180 & 23 \\
\hline
\end{tabular}

Nattanen granite (medium-grained)

\begin{tabular}{|c|c|c|c|c|c|c|c|c|c|c|c|c|c|}
\hline 4003-1A & 75.52 & 0.17 & 12.66 & 1.61 & 0.02 & 0.40 & 0.43 & 3.37 & 4.94 & 0.07 & 99.19 & 201 & 23 \\
\hline 4003-1B & 73.38 & 0.13 & 12.66 & 1.54 & 0.02 & 0.15 & 0.36 & 3.24 & 4.82 & 0.02 & 96.32 & 200 & 22 \\
\hline $4005-1$ & 77.44 & 0.10 & 12.66 & 1.07 & 0.01 & 0.10 & 0.41 & 3.50 & 4.94 & 0.18 & 100.41 & 86 & 25 \\
\hline $4011-1$ & 73.81 & 0.12 & 12.66 & 1.56 & 0.01 & 0.15 & 0.34 & 3.37 & 4.94 & 0.07 & 97.03 & 200 & 22 \\
\hline 4019-1 & 75.73 & 0.08 & 12.85 & 0.99 & 0.01 & 0.05 & 0.34 & 3.24 & 5.18 & 0.02 & 98.49 & 80 & 20 \\
\hline 4028-1 & 75.09 & 0.13 & 12.47 & 1.61 & 0.01 & 0.18 & 0.66 & 3.49 & 4.58 & 0.27 & 98.50 & 164 & 24 \\
\hline $4041-1$ & 73.38 & 0.12 & 12.47 & 1.59 & 0.01 & 0.15 & 0.41 & 3.50 & 4.70 & 0.21 & 96.54 & 205 & 25 \\
\hline 4090-1 & 76.37 & 0.08 & 13.04 & 0.87 & 0.01 & 0.07 & 0.36 & 3.24 & 6.26 & 0.32 & 100.62 & 66 & 28 \\
\hline
\end{tabular}

Nattanen aplite dyke

\begin{tabular}{|c|c|c|c|c|c|c|c|c|c|c|c|c|c|}
\hline $4005-2$ & 77.66 & 0.07 & 12.85 & 0.72 & 0.01 & 0.03 & 0.13 & 4.04 & 4.46 & 0.27 & 100.24 & 97 & 30 \\
\hline $4122-2$ & 77.02 & 0.07 & 12.85 & 0.66 & 0.01 & 0.10 & 0.43 & 3.77 & 4.46 & 0.32 & 99.69 & 79 & 17 \\
\hline $4222-2$ & 75.95 & 0.10 & 12.66 & 0.94 & 0.03 & 0.05 & 0.42 & 3.77 & 4.46 & 0.02 & 98.40 & 90 & 24 \\
\hline
\end{tabular}


Table 2. (cont.)

\begin{tabular}{|c|c|c|c|c|c|c|c|c|c|c|c|c|c|}
\hline Sample & $\begin{array}{c}\mathrm{SiO}_{2} \\
\text { (wt.\%) }\end{array}$ & $\mathrm{TiO}_{2}$ & $\mathrm{Al}_{2} \mathrm{O}_{3}$ & $\mathrm{FeOt}$ & $\mathrm{MnO}$ & $\mathrm{MgO}$ & $\mathrm{CaO}$ & $\mathrm{Na}_{2} \mathrm{O}$ & $\mathrm{K}_{2} \mathrm{O}$ & $\mathbf{P}_{2} \mathbf{O}_{5}$ & Tot & $\begin{array}{c}\mathrm{Zr} \\
(\mathbf{p p m})\end{array}$ & $\begin{array}{c}\mathbf{G a} \\
(\mathbf{p p m})\end{array}$ \\
\hline \multicolumn{14}{|c|}{ Nattanen rhyolite dyke } \\
\hline $4093-1$ & 77.23 & 0.08 & 13.04 & 1.07 & 0.01 & 0.05 & 0.48 & 3.50 & 5.18 & 0.27 & 100.91 & 95 & 27 \\
\hline 4107 & 6.16 & 0.10 & 12.66 & 1.13 & & 0.03 & 0.43 & 3.64 & 4.46 & 0.11 & 98.73 & 116 & 26 \\
\hline $4111-2$ & 74.66 & 0.08 & 12.85 & 1.04 & 01 & 0.08 & 0.35 & 2.97 & 5.06 & 0.21 & 97.31 & 132 & 26 \\
\hline $4138-2$ & 75.3 & 0.10 & 13.23 & 1.23 & 0.03 & 0.05 & 0.53 & 3.77 & 4.70 & 0.11 & 99.05 & 121 & 22 \\
\hline $4138-3$ & 76.37 & 0.10 & 12.66 & 1.49 & & 0.08 & 0.60 & & 4.46 & .16 & 99.85 & 130 & 26 \\
\hline $4140-1$ & 76.59 & 0.08 & 13.04 & 1.05 & 01 & 0.03 & 0.41 & 4.18 & 4.34 & .25 & 99.98 & 93 & 22 \\
\hline $4140-2$ & 75.09 & 0.05 & 12.85 & 1.14 & 0.03 & 0.03 & 0.52 & 4.31 & 4.34 & 0.14 & 98.50 & 79 & 31 \\
\hline $4245-1$ & 76.37 & 0.05 & 12.85 & 1.11 & 0.01 & 0.02 & 0.36 & 3.64 & 4.58 & 0.00 & 98.99 & 100 & 25 \\
\hline $4247-1$ & 75.09 & 0.07 & 13.04 & 1.18 & 01 & 0.07 & 0.28 & 3.50 & 4.82 & 0.00 & 98.06 & 100 & 22 \\
\hline $4249-1$ & 75.09 & 0.07 & 13.23 & 0.66 & & 0.02 & 0.28 & 3.91 & 4.58 & 0.04 & 97.89 & 100 & 25 \\
\hline $4251-1$ & 73.38 & 0.03 & 13.23 & 1.08 & 0.01 & 0.02 & 0.20 & 3.37 & 4.70 & 0.11 & 96.13 & 110 & 31 \\
\hline $4262-1$ & 76.16 & 0.08 & 13.42 & 0.85 & & 0.05 & 0.41 & 45 & 3.49 & .23 & 99.18 & 100 & 24 \\
\hline $4269-1$ & 74.88 & 0.05 & 12.85 & 0.93 & & 0.02 & 0.21 & 3.64 & 4.34 & 0.05 & 96.98 & 110 & 29 \\
\hline $4271-1$ & 74.23 & 0.05 & 13.04 & 1.20 & 0.01 & 0.07 & 0.35 & 3.24 & 4.94 & 0.05 & 97.18 & 110 & 20 \\
\hline 4289-1 & 74.23 & 0.08 & 12.85 & 1.32 & 0.01 & 0.08 & 0.32 & 3.24 & 4.94 & 0.05 & 97.12 & 120 & 23 \\
\hline $4291-1 \mathrm{~A}$ & 74.45 & 0.08 & 12.85 & 1.08 & & 0.03 & 0.22 & 3.24 & 4.94 & 0.14 & 97.04 & 110 & 21 \\
\hline 4291-1B & 75.30 & 0.07 & 12.85 & 1.12 & 0.01 & 0.05 & 0.22 & 2.97 & 5.18 & 0.02 & 97.79 & 120 & 22 \\
\hline $4293-2 \mathrm{~A}$ & 75.73 & 0.07 & 13.23 & 0.80 & 0.01 & 0.05 & 0.15 & 3.77 & 4.46 & 0.02 & 98.29 & 110 & 29 \\
\hline 4299-1 & & 0.07 & 13.23 & 0.96 & & & & & 4.46 & .02 & 98.04 & 90 & 28 \\
\hline $4304-1$ & 74.02 & 0.03 & 12.85 & 0.80 & 0.01 & 0.03 & 0.36 & 3.37 & 4.94 & 0.02 & 96.43 & 140 & 25 \\
\hline $4306-3$ & 73.81 & 0.12 & 13.23 & 1.22 & 0.04 & 0.08 & 0.8 & 3.24 & 5.06 & 0.07 & 97.67 & 160 & 20 \\
\hline 4314-1 & 75.09 & 0.08 & 13.04 & 0.89 & 0.01 & 0.05 & 0.31 & 3.37 & 5.18 & 0.05 & 98.07 & 140 & 23 \\
\hline $4318-1$ & 73.59 & 0.15 & 13.04 & 1.30 & 0.02 & 0.03 & 0.31 & 3.50 & 5.66 & 0.02 & 97.62 & 120 & 21 \\
\hline $4318-2$ & 74.23 & 0.17 & 13.23 & 0.62 & 0.01 & 0.03 & 0.38 & 3.77 & 4.82 & 0.02 & 97.28 & 140 & 22 \\
\hline $4318-6$ & 75.09 & 0.10 & 12.85 & 1.04 & 0.01 & 0.05 & 0.31 & 3.24 & 4.82 & 0.05 & 97.56 & 150 & 24 \\
\hline $4235-1 \mathrm{~A}$ & 76.59 & 0.05 & 13.23 & 0.84 & & 0.07 & 0.17 & 4.04 & 4.34 & 0.00 & 99.39 & 90 & 27 \\
\hline $4235-1 \mathrm{~B}$ & 76.8 & 0.08 & 12.85 & 1.11 & 0.03 & 0.05 & 0.46 & 3.37 & 4.58 & 0.00 & 99.33 & 110 & 25 \\
\hline $4235-2$ & 74.88 & 0.07 & 13.04 & 1.26 & 0.03 & 0.10 & 0.41 & 3.10 & 5.42 & 0.00 & 98.31 & 120 & 24 \\
\hline $4231-1$ & 75.09 & 0.08 & 12.47 & 1.16 & & 0.10 & 0.35 & 3.10 & 4.82 & 0.00 & 97.18 & 140 & 22 \\
\hline $4278-1$ & 75.73 & 0.10 & 13.04 & 0.85 & 0.01 & 0.15 & 0.17 & 3.37 & 4.34 & 0.07 & 97.83 & 190 & 20 \\
\hline $4312-2$ & 76.16 & 0.07 & 13.23 & 0.40 & 0.01 & 0.03 & 0.17 & 3.64 & 5.06 & 0.3 & 99.07 & 140 & 23 \\
\hline $4335-2 \mathrm{~A}$ & 75.95 & 0.10 & 12.85 & 1.14 & 0.01 & 0.15 & 0.13 & 2.70 & 4.46 & 0.09 & 97.58 & 150 & 22 \\
\hline $4363-2$ & 75.3 & 0.05 & 12.85 & 0.93 & 0.01 & 0.08 & 0.11 & 3.24 & 4.82 & 0.07 & 97.46 & 110 & 22 \\
\hline $4371-1$ & 75.09 & 0.03 & 12.85 & 0.58 & 0.01 & 0.05 & 0.21 & 4.04 & 4.10 & 0.07 & 97.03 & 110 & 25 \\
\hline
\end{tabular}

*) Methods for data: All major element samples were analysed by atomic absorbtion spectrophotometer (AAS) at Geological survey of Finland (GTK).

$\mathrm{Zr}$ analyses were done by energy dispersive $\mathrm{X}$-ray spectroscopy (EDX), and Ga analyses by optical emission spectrometry

$(\mathrm{OES})$ at Geological Survey of Finland (GTK). 


\section{I. Elemental geochemistry}

\section{I.I. General description}

Figure 4 shows the major element composition of the Nattanen-type granites of Finland. The granites are alkali-calcic to calc-alkaline (Fig. 4a) and marginally peraluminous (A/CNK between 1.0 and about 1.1; Fig. $4 b) . \mathrm{SiO}_{2}$ content is high ( $-70-78$ wt.\%) and the $\mathrm{Mg \#}$ (Fig. 4j) and $\mathrm{MgO}$ values are mainly low (0-39 and $<0.09-0.76 \mathrm{wt} . \%$, respectively). The Nattanen stock and related aplite and rhyolite dykes are the most evolved, whereas the Vainospää and Riestovaara granites are the least evolved (Fig. 4). $\mathrm{TiO}_{2}, \mathrm{FeOt}, \mathrm{MgO}$ and $\mathrm{CaO}$ show a negative correlation with $\mathrm{SiO}_{2}$ (Fig. 4c-f). The $\mathrm{Na}_{2} \mathrm{O}(2.7-4.7$ wt.\%) and $\mathrm{K}_{2} \mathrm{O}(3.5-6.5$ wt.\%) values are high, $\mathrm{CaO}$ values are low (0.1-1.9 wt.\%; Fig. 4). $\mathrm{K}_{2} \mathrm{O} / \mathrm{Na}_{2} \mathrm{O}$ varies between 0.81 and 1.60 (average 1.25).

The Nattanen-type granites show generally high average contents of the LIL elements (Ba 790 ppm, Rb 208 ppm, Sr 153 ppm), Ga (27 ppm), Nb (15 ppm), Th (31 ppm), U (5 ppm) and Zr (219 ppm); compatible trace elements are mostly below the detection limit (Table 3). Figure 5a shows chondritenormalized REE distributions of the Nattanen-type granites. Overall, the REE contents are rather high for felsic rocks. The REE patterns are steeply fractionated $\left[(\mathrm{La} / \mathrm{Yb})_{\mathrm{N}}-50\right.$ in average] with a moderate negative $\mathrm{Eu}$ anomaly $\left(\mathrm{Eu} / \mathrm{Eu}^{*}-0.4\right)$. In primitive mantlenormalized diagrams (Fig. 5b) all the Nattanen-type granites show similar patterns: they are rich in incompatible elements and display negative $\mathrm{Ta}, \mathrm{Nb}, \mathrm{Sr}, \mathrm{P}$ and $\mathrm{Ti}$ anomalies.

\section{I.2. Classification}

In previous studies (Haapala et al., 1987; Front et al., 1989), the Nattanen-type granites were considered as I-type on the basis of mineral composition (magnetite and titanite as characteristic accessory minerals) and the currently available geochemical discrimination criteria (high $\mathrm{Na}_{2} / \mathrm{K}_{2} \mathrm{O}$, Fig. 6a; relatively weak alumina saturation, Fig. 4b). The authors mentioned that some varieties of these granites show $\mathrm{S}$ type and A-type geochemical characteristics. In the $\mathrm{Rb}$ vs. $(\mathrm{Y}+\mathrm{Nb})$ classification diagram of Pearce et al. (1984) (Fig. 6b) the Nattanen-type granites plot in the volcanic arc granite field; some of the Vainospää and Riestovaara samples fall, however, into the syncollisional granite field. According to Pearce (1996) post-collisional granites are difficult to classify with the $\mathrm{Rb}$ vs. $(\mathrm{Y}+\mathrm{Nb})$ diagram because of their variable source.

In the new classification scheme of Dall'Agnol \& Oliveira (2007), designed to separate calc-alkaline granites from A-type granites and oxidized Atype granites from reduced A-type granites, the Nattanen-type granites show a consistent A-type character. In the $\mathrm{CaO} /\left(\mathrm{FeOt}+\mathrm{MgO}+\mathrm{TiO}_{2}\right)$ vs. $\mathrm{CaO}+\mathrm{Al}_{2} \mathrm{O}_{3}$ (Fig. 6c) and $\mathrm{CaO} /\left(\mathrm{FeOt}+\mathrm{MgO}+\mathrm{TiO}_{2}\right)$ vs. $\mathrm{Al}_{2} \mathrm{O}_{3}$ diagrams (Fig. 6d), the Nattanen-type granites fall mostly in the A-type granite field and they differ clearly from the calc-alkaline granites. However, it should be noted that the Riestovaara and Vainospää granites show partly calc-alkaline (high $\mathrm{CaO}$ ) characteristics. In the $\mathrm{FeOt} /(\mathrm{FeOt}+\mathrm{MgO})$ vs. $\mathrm{Al}_{2} \mathrm{O}_{3}$ (Fig. 6e) and $\mathrm{FeOt} /(\mathrm{FeOt}+\mathrm{MgO})$ vs. $\mathrm{Al}_{2} \mathrm{O}_{3} /\left(\mathrm{K}_{2} \mathrm{O} / \mathrm{Na}_{2} \mathrm{O}\right)$ diagrams (Fig. 6f), the Nattanen-type granites are transitional between reduced A-type granites, oxidized Atype granites, and calc-alkaline granites, mostly because of their moderate enrichment in $\mathrm{FeO}$ relative to $\mathrm{MgO}$. The majority of the Nattanen-type granites are oxidized A-type granites. Rhyolite dykes from the Nattanen stock show strongest the FeOt enrichment compared to $\mathrm{MgO}$ and the dykes show reduced Atype characteristics. The Vainospää and Riestovaara

Fig. 4. Composition of the Nattanen, Tepasto, Pomovaara, Riestovaara, and Vainospää granites and related dyke rocks shown in a) $\mathrm{Na}_{2} \mathrm{O}+\mathrm{K}_{2} \mathrm{O}-\mathrm{CaO}$ vs. $\mathrm{SiO}_{2}$ (fields from Frost et al., 200I); b) $\mathrm{A} / \mathrm{CNK}$ vs. $\mathrm{SiO}_{2}$; c) $\mathrm{TiO}_{2}$ vs. $\mathrm{SiO}_{2}$; d) $\mathrm{FeOt}$ vs. $\mathrm{SiO}_{2}$; e) $\mathrm{MgO}$ vs. $\mathrm{SiO}_{2}$; f) $\mathrm{CaO}$ vs. $\mathrm{SiO}_{2}$; g) $\mathrm{Na}_{2} \mathrm{O}$ vs. $\mathrm{SiO}_{2}$; h) $\mathrm{K}_{2} \mathrm{O}$ vs. $\mathrm{Al}_{2} \mathrm{O}_{3}$; i) $\mathrm{P}_{2} \mathrm{O}_{5}$ vs. $\mathrm{SiO}_{2}$; j) $\mathrm{Mg \#}^{2}$ vs. $\mathrm{SiO}_{2}$ (expressed as cationic proportions, $\mathrm{Mg \#}=100 \times\left(\mathrm{Mg}^{2+} /\left(\mathrm{Mg}^{2+}+\mathrm{Fe}^{2+}\right)\right)$ diagrams. 

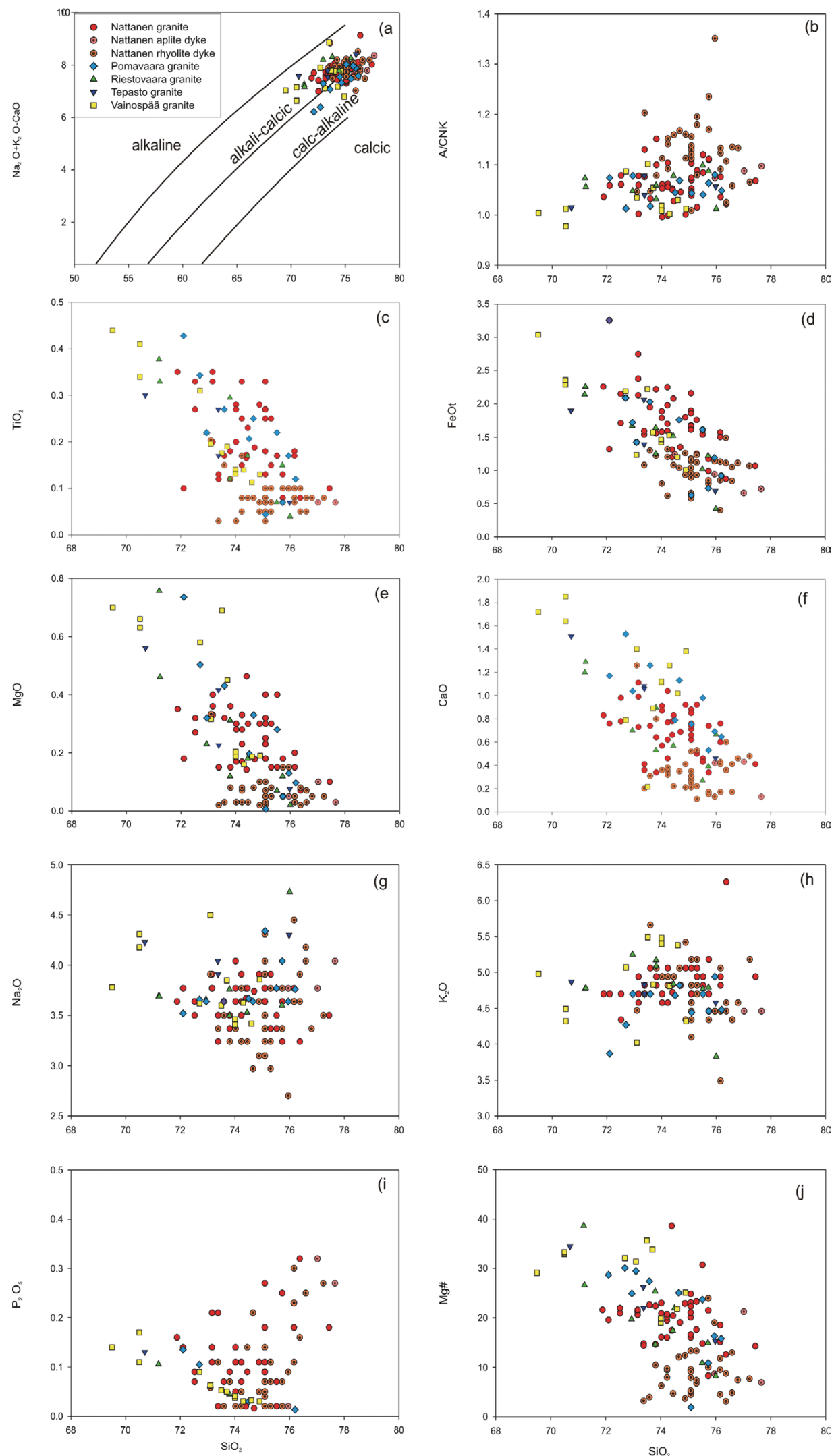


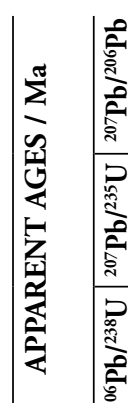

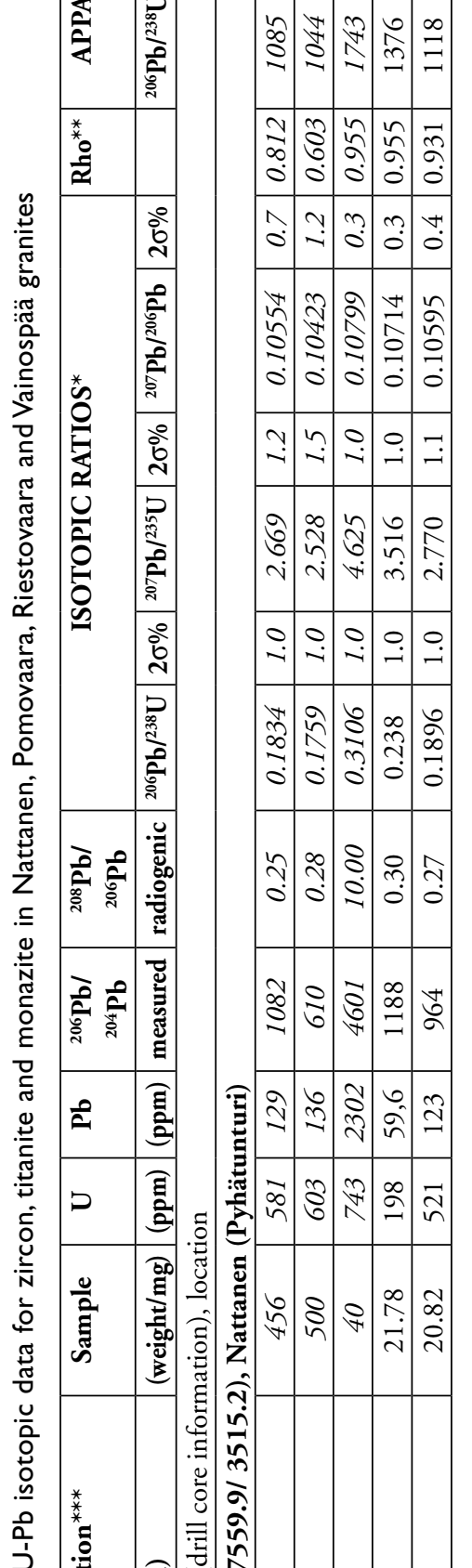

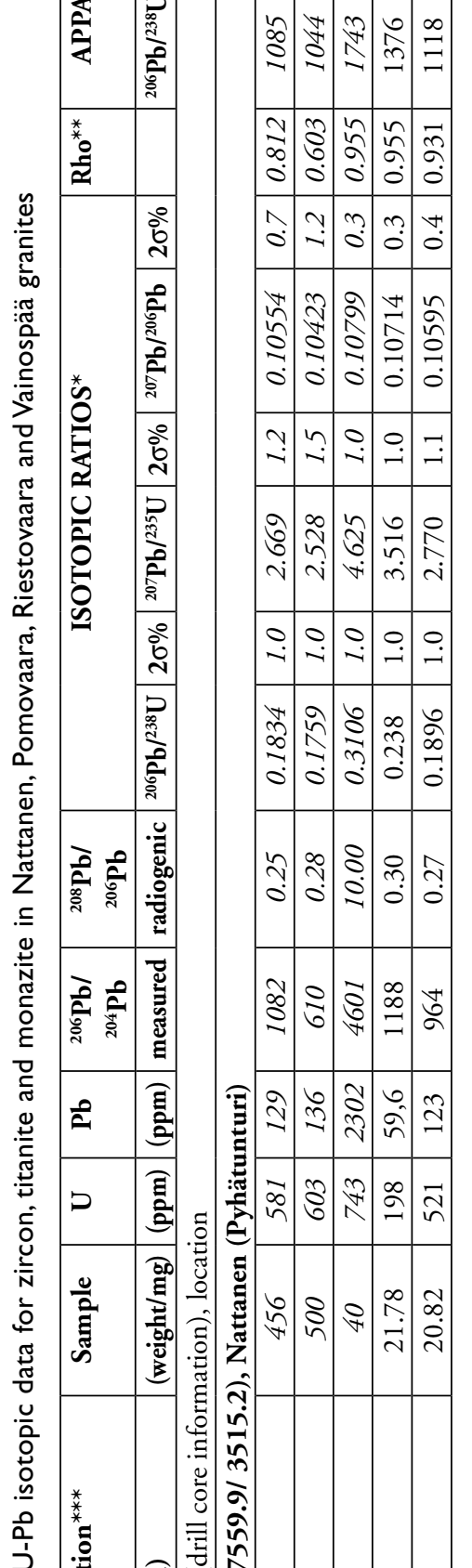

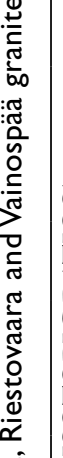

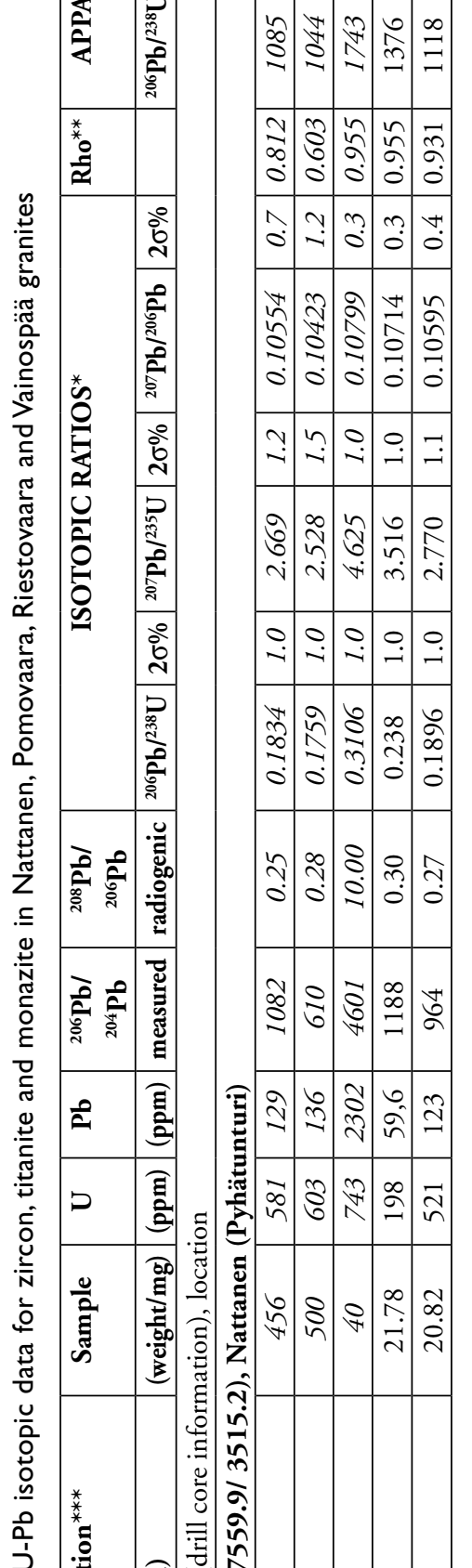

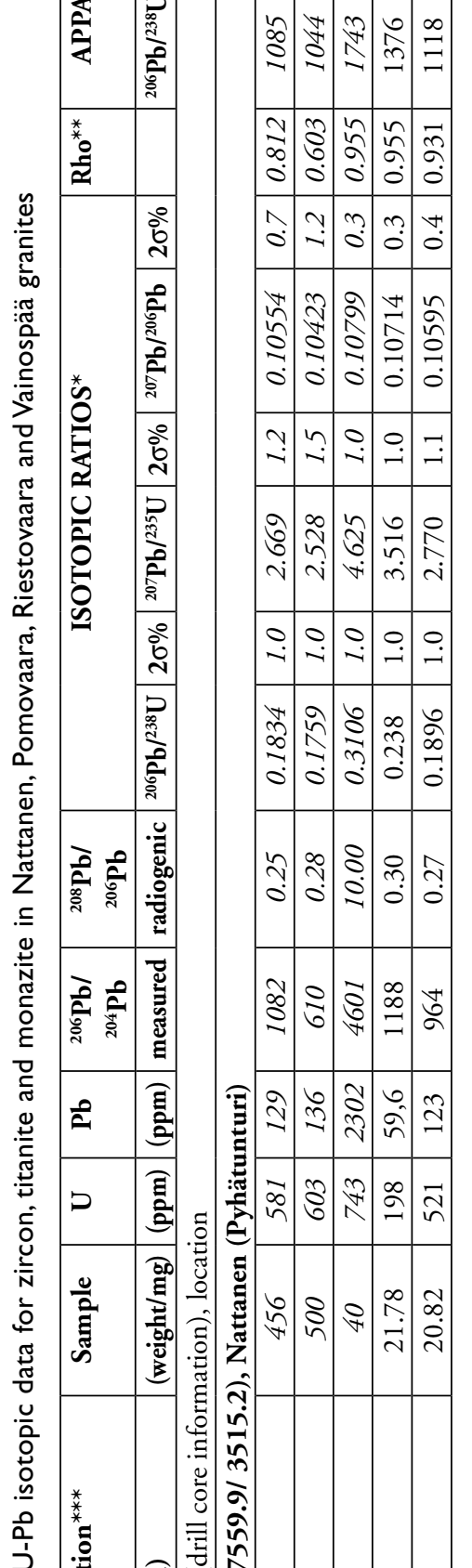

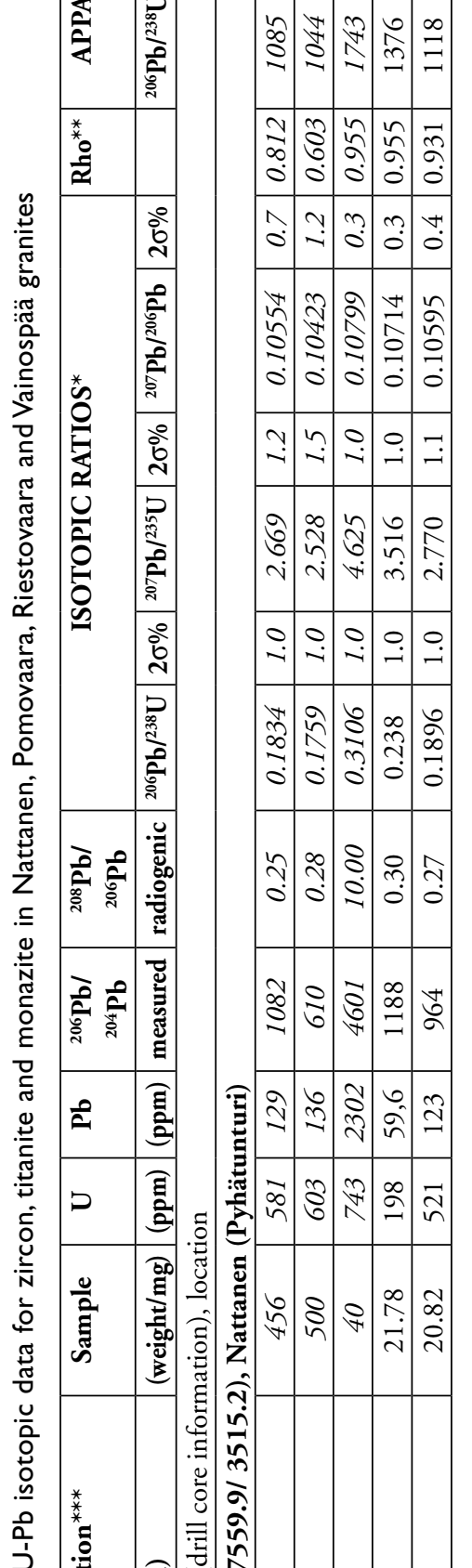

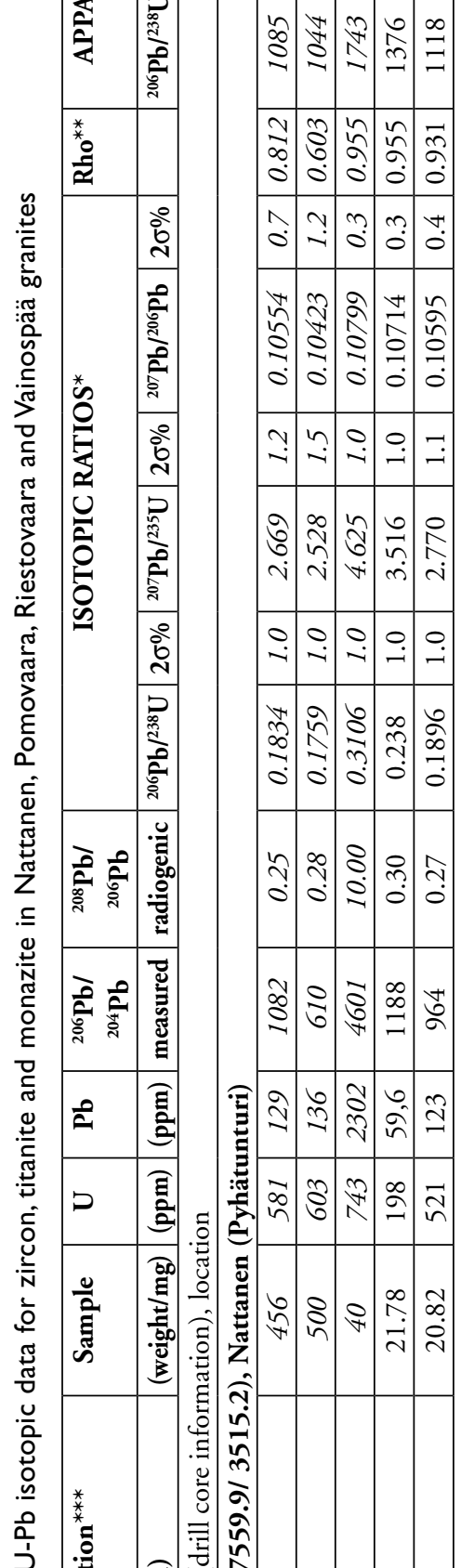

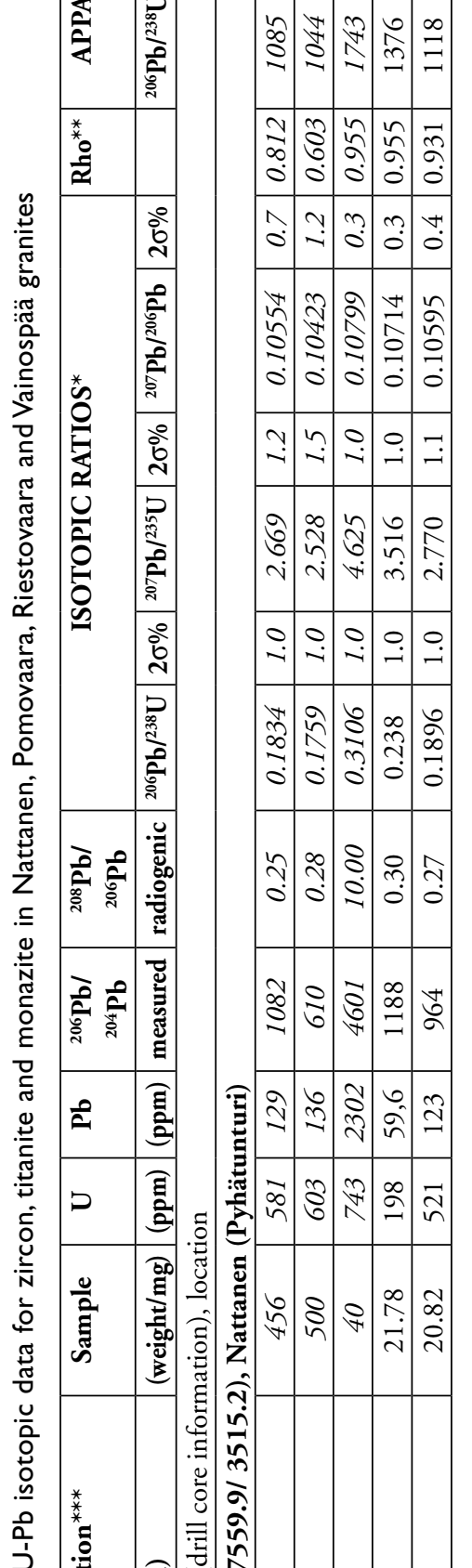

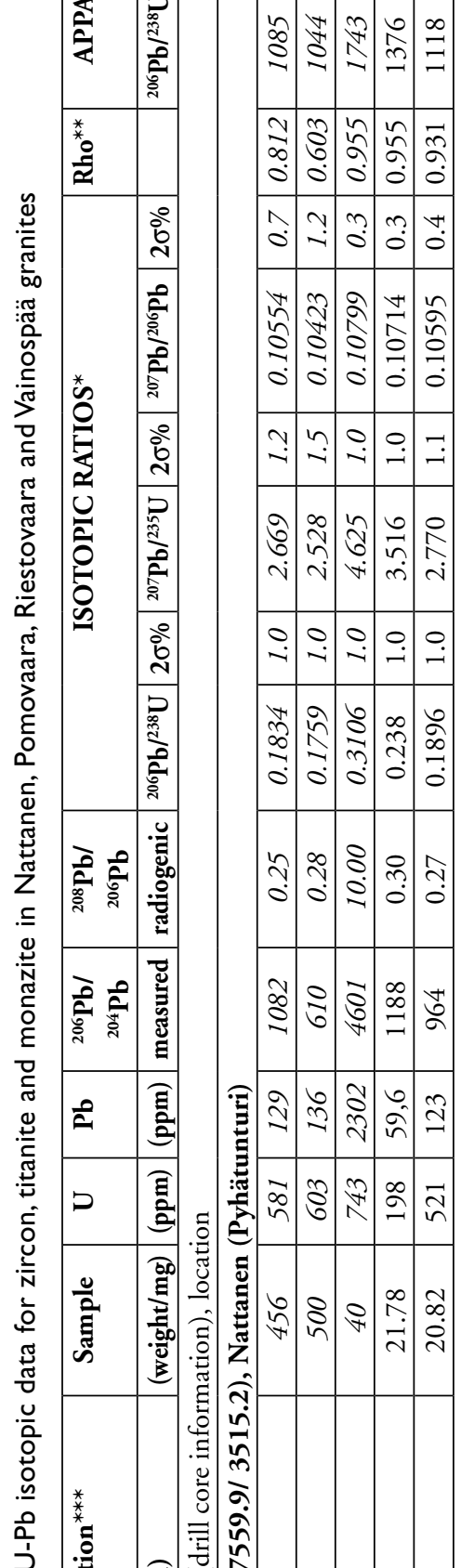

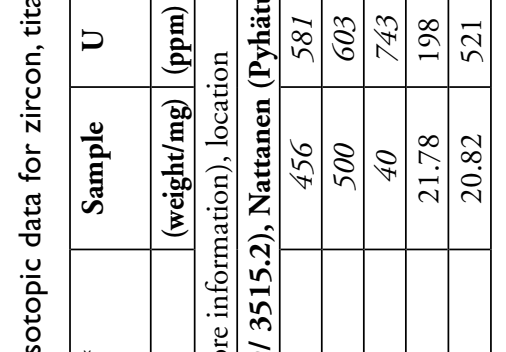

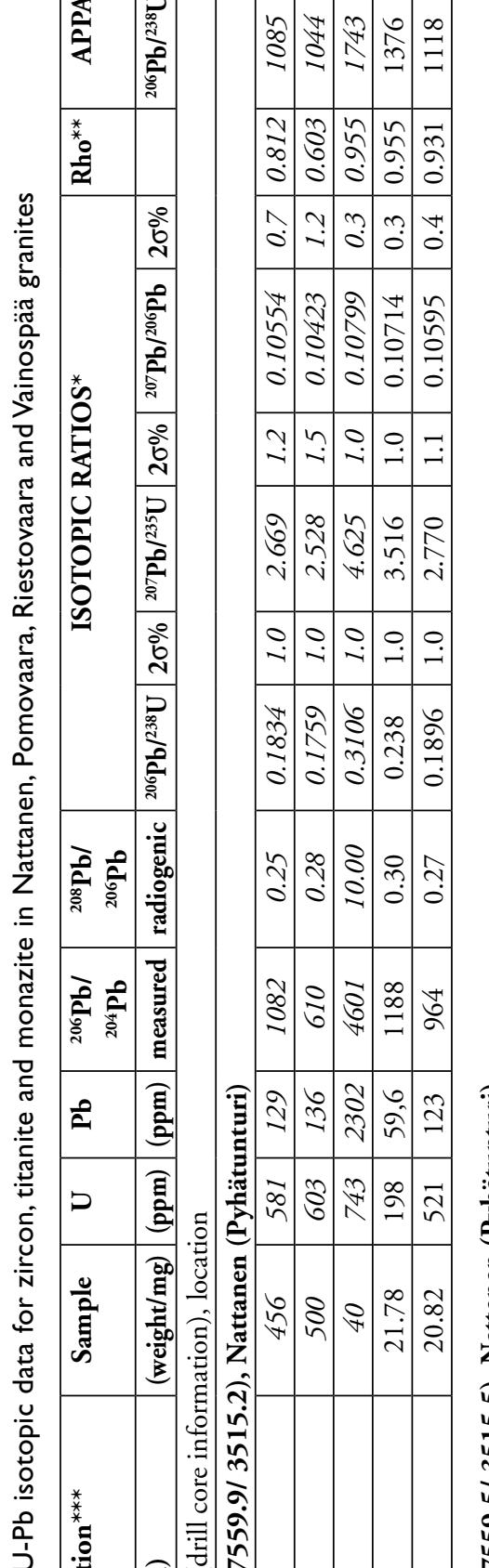

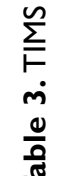

लि

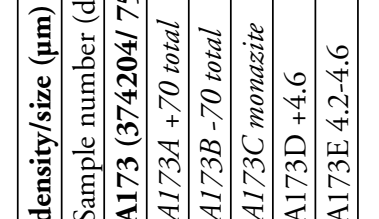

\begin{tabular}{|c|c|c|c|c|}
\hline 2 & $\underset{\mathbb{N}}{\mathbb{N}}$ & & $\begin{array}{c}1 \\
0 \\
-1\end{array}$ & $\stackrel{n}{\approx}$ \\
\hline$\underset{n}{\sharp}$ & $\begin{array}{l}\stackrel{0}{\beth} \\
\approx\end{array}$ & $\begin{array}{l}\hat{v} \\
\hat{v}\end{array}$ & 昰 & $\begin{array}{l}\tilde{\sigma} \\
\approx\end{array}$ \\
\hline$\underset{\infty}{\infty}$ & ¿ & 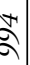 & $\stackrel{8}{2}$ & $\stackrel{\not े}{\circ}$ \\
\hline $\begin{array}{l}\alpha \\
\alpha \\
\end{array}$ & م) & 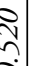 & $\begin{array}{l}0 \\
0\end{array}$ & $\hat{\tilde{\sigma}}$ \\
\hline & & & & 0 \\
\hline- & 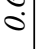 & $\stackrel{?}{\sim}$ & 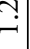 & ?. \\
\hline $\begin{array}{l}\infty \\
\tilde{r}\end{array}$ & 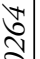 & $\begin{array}{l}0 \\
\vdots \\
\\
\end{array}$ & 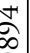 & $\hat{\approx}$ \\
\hline $0^{2}$ & $\overrightarrow{0}$ & $\overrightarrow{0}$ & $\dot{0}$ & $\overrightarrow{0}$ \\
\hline$\underset{-}{-}$ & $\stackrel{?}{-}$ & $\stackrel{n}{n}$ & 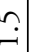 & $\stackrel{\circ}{\circ}$ \\
\hline $\bar{\delta}$ & $\stackrel{2}{\beth}$ & ( & $\stackrel{n}{n}$ & $\widehat{N}$ \\
\hline 0 & 0 & 0.1 & 0. & 0 . \\
\hline & & & & \\
\hline $\mathbb{I}$ & $\stackrel{5}{\curvearrowleft}$ & $\stackrel{0}{0}$ & $\overrightarrow{\tilde{c}}$ & $\underset{\infty}{\stackrel{7}{\infty}}$ \\
\hline $0^{\circ}$ & 0 & & 0 & $\overline{0}^{\circ}$ \\
\hline กิ? & & $\hat{n} \tilde{n}$ & & กี \\
\hline
\end{tabular}

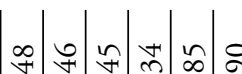

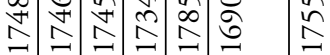

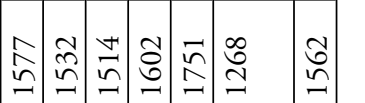

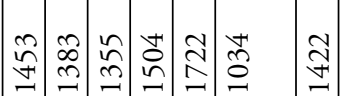

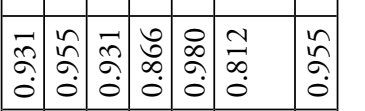

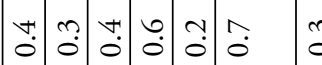

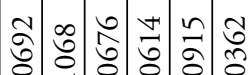

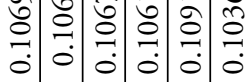

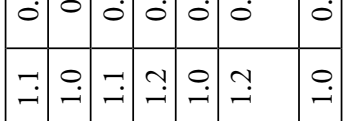

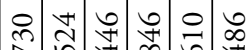

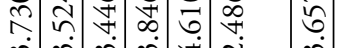

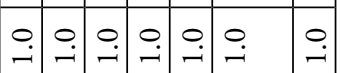

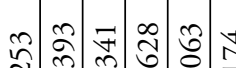

กิ กิ กิ กิ กิ กิ

\begin{tabular}{ll|l|l|}
\hline & & &
\end{tabular}

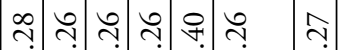

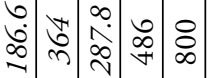

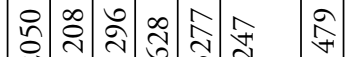

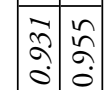

\begin{tabular}{|c|c|}
\hline & 0 \\
0 & 0 \\
\hline 0 & 0 \\
\hline
\end{tabular}

$\begin{array}{ll}\Downarrow \\ \infty \\ \infty & \infty \\ 0 & 0 \\ 0 & 0\end{array}$

$\begin{array}{cc}2 & 1 \\ 2 & 0 \\ 0 & 0 \\ 0\end{array}$

$\because 0$

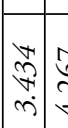

\begin{tabular}{l|c}
0 \\
\hline-1
\end{tabular}

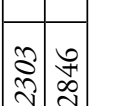

$0 \%$

ก

กิ

$+$

늘

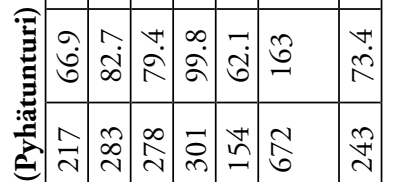

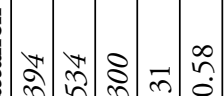

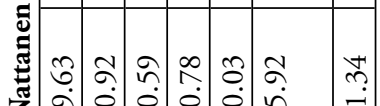

ż

क़े

bे

n

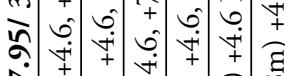

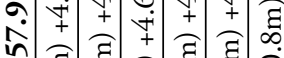

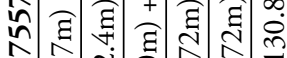

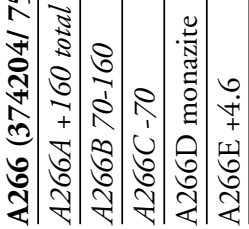

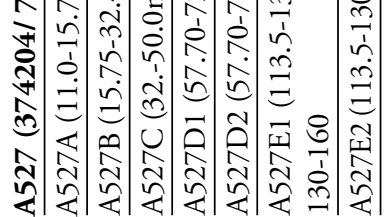

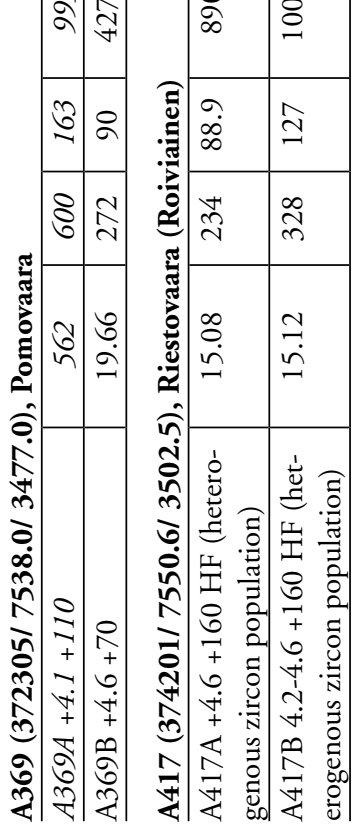




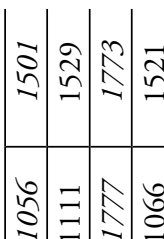

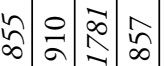

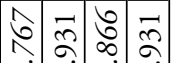

०) : 0 :

t?

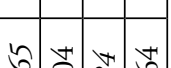

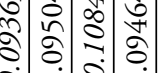

$\therefore: 0$.

$\underset{-}{-} \cong \because$

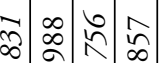

$-i$

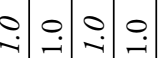

$\sim \approx \infty$

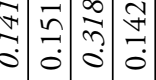

จิ่ ปิ่

$\circ:$

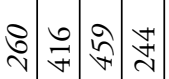

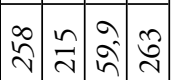

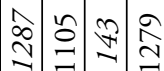

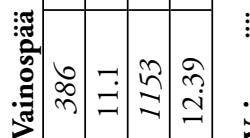

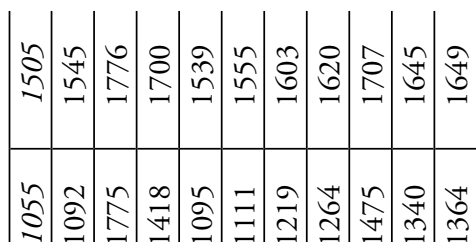

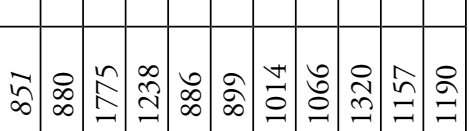

ปี่

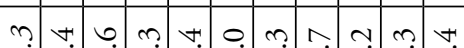

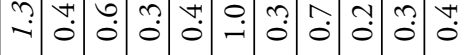

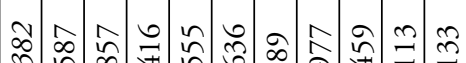

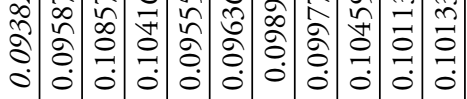

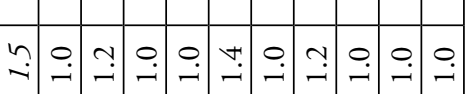

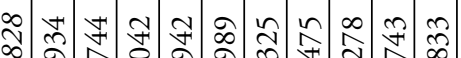

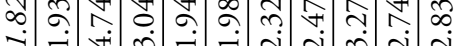

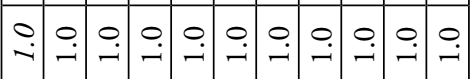

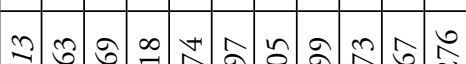

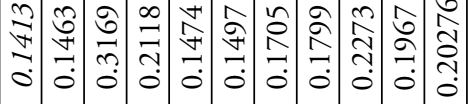

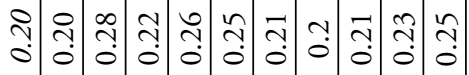

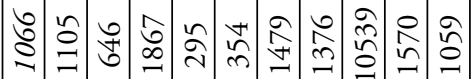

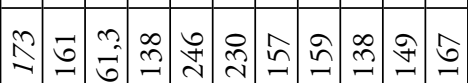

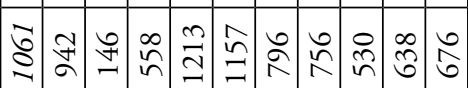

范

$m \backsim$ สิ

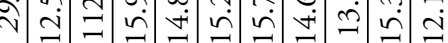

के

$\underset{⿱ 亠 乂}{+}$

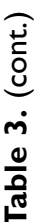

$\stackrel{\infty}{7}$

N

츠

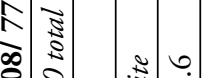

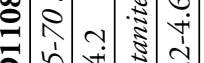

จิ

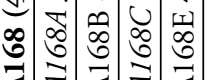

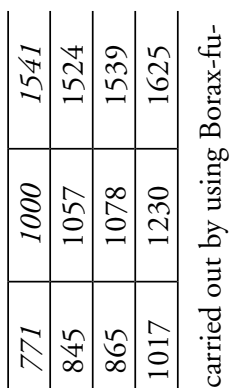

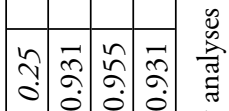

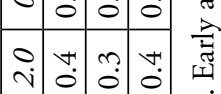

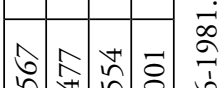

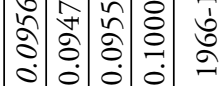

걸

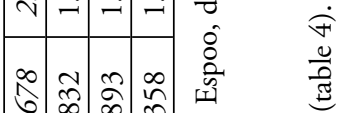

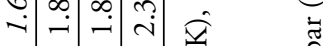

엉요

싱ำ

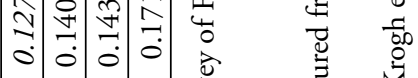

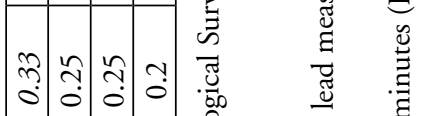

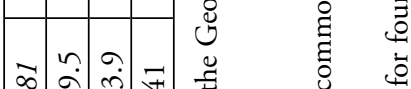

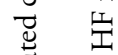

3 1 क

嵒

密

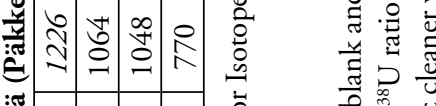

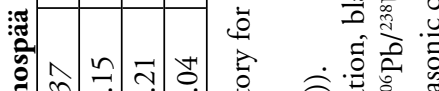

$\widehat{\overline{1}}$

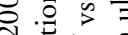

늈

눙

$\Rightarrow \quad$

$\widetilde{\square}$.

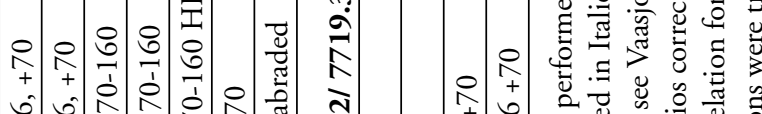

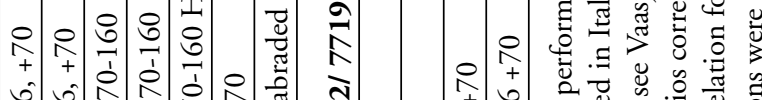

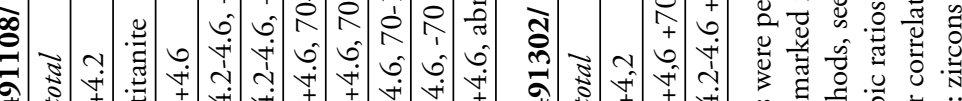

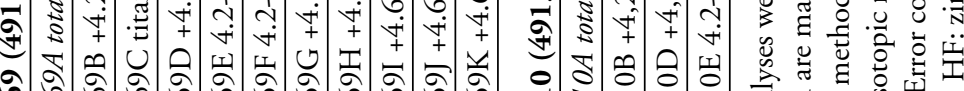

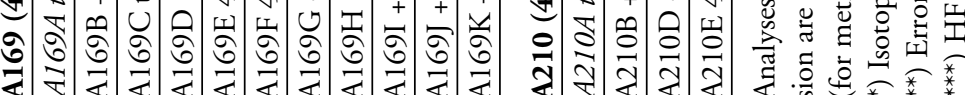



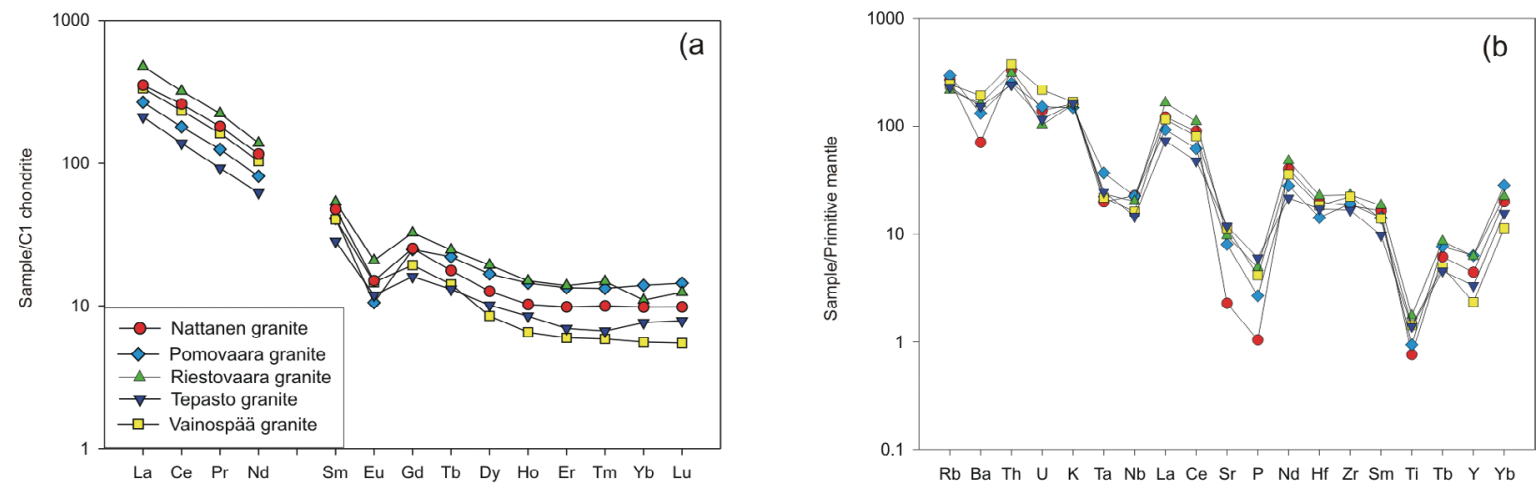

Fig. 5. Trace element composition of representative analyses from Nattanen (92009683), Tepasto (93001676), Pomovaara (92009552), Riestovaara (92009544), and Vainospää (9500। 306) granites shown in a) chondrite-normalized rare earth elements diagram; b) mantle-normalized spider diagram. Normalization values are from Sun and McDonough (1989).

granites fall between the oxidized A-type and calc-alkaline classes. In the classification scheme of Whalen et al. (1987), the Nattanen-type granites show clear A-type characteristics and fall apart from the S-, M-, and I-type granites, mainly because of their high $\mathrm{Ga} /$ $\mathrm{Al}$ and Ce values. Obviously, the Nattanen-type granites can be rightfully considered as oxidized A-type granites.

\subsection{Zircon saturation thermometry}

Zircon saturation temperatures (Watson \& Harrison, 1983) calculated for the Nattanen-type granites are in the $720-880{ }^{\circ} \mathrm{C}$ range (Fig. 7). Samples from the granite plutons mostly show temperatures above
$760{ }^{\circ} \mathrm{C}$, whereas the temperatures calculated for the rhyolitic and aplitic dykes are somewhat lower in average. The $\mathrm{U}-\mathrm{Pb}$ zircon data acquired for the Nattanen-type granites (e.g., Meriläinen, 1976; Rastas et al., 2001; this volume) indicate that the amount of inherited zircon is very small and thus the calculated zircon saturation temperatures may be considered at least fair estimates of the actual crystallization temperatures (e.g., Miller et al., 2001).

Zircon saturation temperatures after Watson and Harrison (1983) from other geochemically A-type granites in Finland give the following results: the Honkajoki post-kinematic granite in the central Finland granitoid complex 825-900 ${ }^{\circ} \mathrm{C}$ (Elliott, 2001), the Bodom and Obbnäs rapakivi granites in southern

Fig. 6. Classification diagrams of the Nattanen, Tepasto, Pomovaara, Riestovaara, and Vainospää granites and related dykes. a) $\mathrm{Na}_{2} \mathrm{O}$ vs. $\mathrm{K}{ }_{2} \mathrm{O}$ after White and Chappell (1983). b) Rb vs. Y+Nb after (Pearce et al., 1984), abbrevations of the fields: Syn-COL = syncollisional granites; $\mathrm{WPG}=$ within-plate granites; $\mathrm{VAG}=$ volcanic arc granites; ORG = ocean ridge granites. c) $\left.\mathrm{CaO} / \mathrm{FeOt}+\mathrm{MgO}+\mathrm{TiO}_{2}\right)$ vs. $\mathrm{CaO}+\mathrm{Al}_{2} \mathrm{O}_{3}$; d) $\mathrm{CaO} /\left(\mathrm{FeOt}+\mathrm{MgO}+\mathrm{TiO}_{2}\right)$ vs. $\left.\mathrm{Al}_{2} \mathrm{O}_{3} ; \mathrm{e}\right) \mathrm{FeOt} /$ $\left.\left(\mathrm{FeOt}+\mathrm{MgO}+\mathrm{TiO}_{2}\right) ; \mathrm{f}\right) \mathrm{FeOt} /(\mathrm{FeOt}+\mathrm{MgO})$ vs. $\mathrm{Al}_{2} \mathrm{O}_{3} /\left(\mathrm{K}_{2} \mathrm{O} / \mathrm{Na}_{2} \mathrm{O}\right)$, figures c-f after Dell'Agnol and Oliveira (2007);g) $\mathrm{Zr}$ vs. $10000 \times \mathrm{Ga} / \mathrm{Al}$; h) Ce vs. $10000 \times \mathrm{Ga} / \mathrm{Al}$; i) Y vs. $10000 \times \mathrm{Ga} / \mathrm{Al}$; j) Nb vs. $10000 \times \mathrm{Ga} / \mathrm{Al}$, figures g-j after Whalen et al., (1987). Comparison fields after representative $\left(\mathrm{SiO}_{2}>65\right.$ wt. \%) analyses of rapakivi granites from Rämö (199I), Rieder et al. (1996) and Kosunen (1999) (from Wiborg, Bodom, and Obbnäs) and representative $\left(\mathrm{SiO}_{2}\right.$ $>65$ wt. \%) shoshonitic rocks after Rutanen et al. (1997) (from southern Finland and Russian Karelia). 

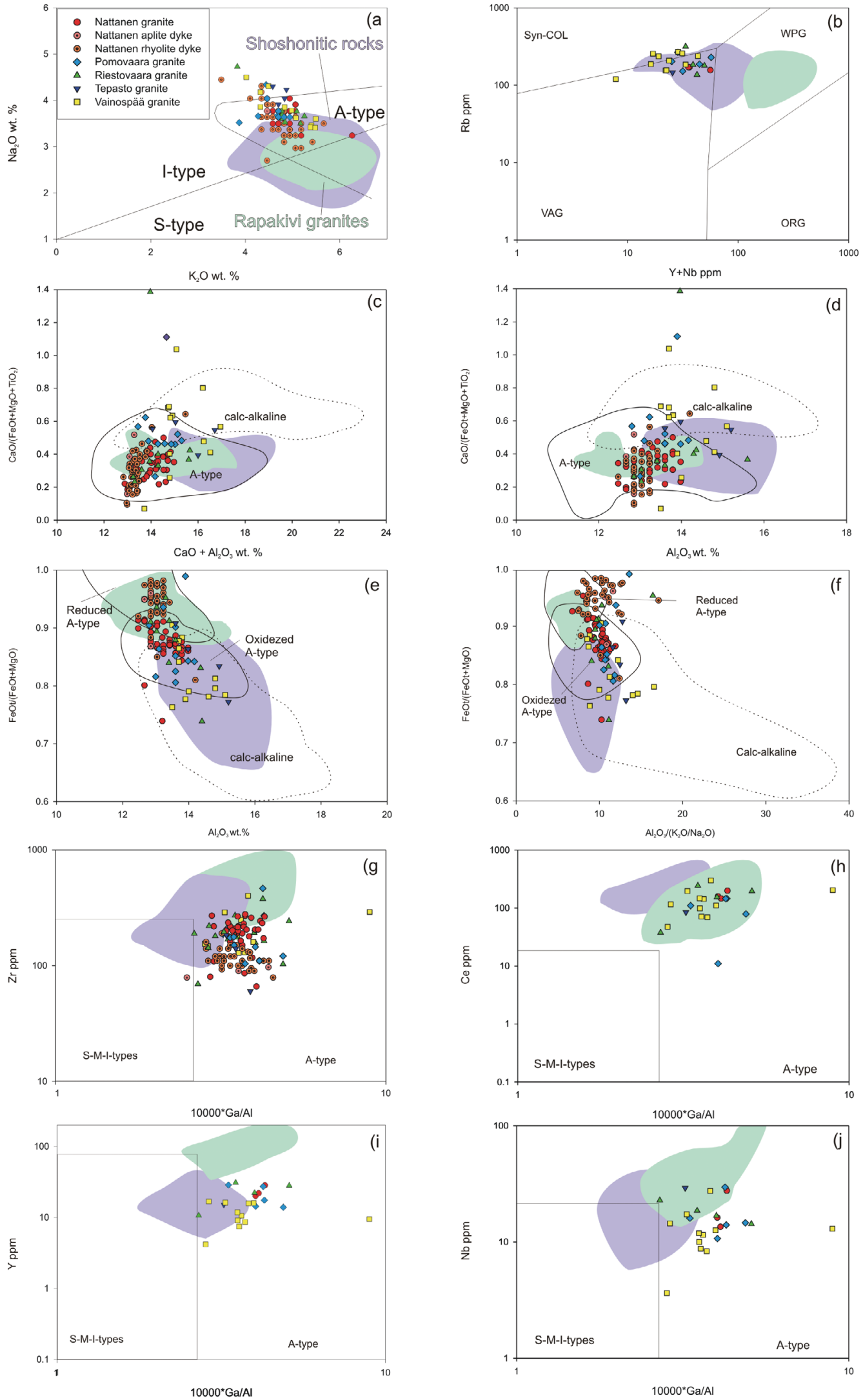


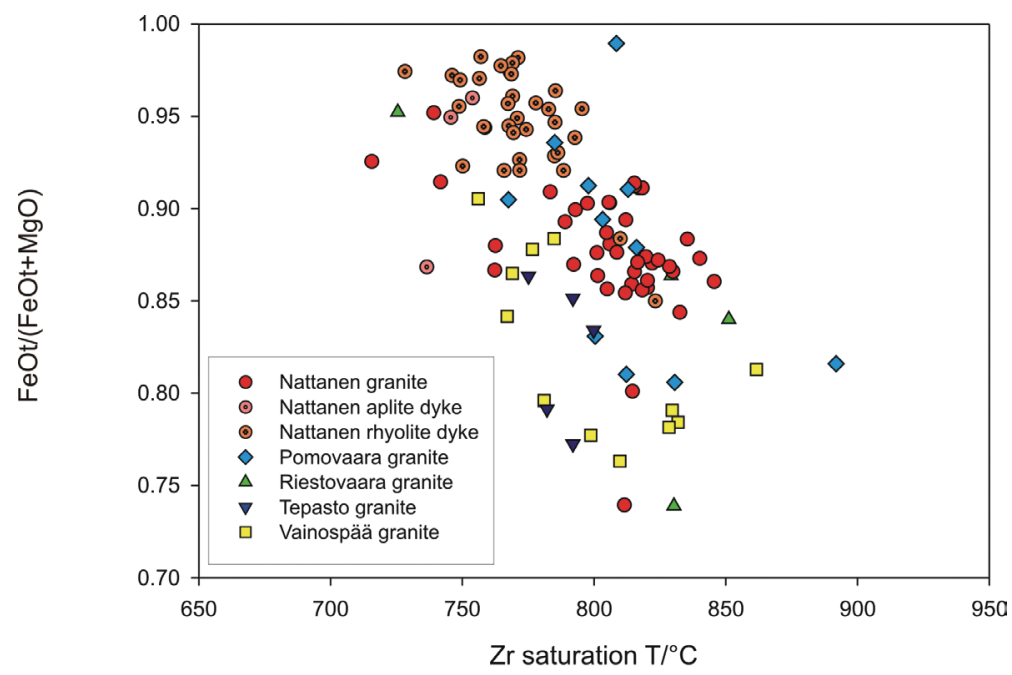

Fig. 7. $\mathrm{FeOt} /(\mathrm{FeOt}+\mathrm{MgO})$ vs. zircon saturation temperature plot for the Nattanen-type granites of Finland. FeOt denotes total iron as $\mathrm{FeO}$, zircon saturation temperatures calculated according to Watson and Harrison (1983).
Finland $830-950{ }^{\circ} \mathrm{C}$ (Kosunen, 2004). These are of the same order or slightly higher than the temperatures calculated for the Nattanen-type granites.

\section{Isotope geology}

In the 1970's isotope geological studies on the Nattanen-type granites were performed at the Isotope Laboratory of the Geological survey of Finland (GTK) in association with a comprehensive dating project (Meriläinen, 1976). Some U-Pb analyses were made already in the 1960's on zircon, monazite, and titanite using the borax-fusion method. These data, comprising $40 \mathrm{U}-\mathrm{Pb}$ and $30 \mathrm{~Pb}-\mathrm{Pb}$ thermal ionization single collector mass spectrometer (TIMS) analyses, are reported in this paper.

\section{I. U-Pb results}

\section{I.I. Nattanen-type intrusions south of the Lap- land granulite belt}

Twenty one $\mathrm{U}-\mathrm{Pb}$ analyses on zircon and monazite were made from five granite samples (A173, A266, A527, A369, A417) of the Nattanen, Pomovaara, and Riestovaara plutons located south of the LGB (Ta- ble 3, sample locations in Fig. 2). The zircon populations in these samples are rather similar and consist predominantly of euhedral, simple, short prisms. The data show that the common $\mathrm{Pb}$ content is often high and the results are discordant. All data for the Nattanen-type granites, including two borax-fusion analyses on monazite, plot roughly along a chord that gives intercept ages of $121 \pm 43 \mathrm{Ma}$ and $1775 \pm 10 \mathrm{Ma}$ (Fig. 8a). In the five samples analyzed, high MSWD of 18 is indicative of substantial scatter in excess of analytical error, which may partly be due to varying zircon populations.

The regression line tilted through the five analyses of Nattanen sample A173 intercept the concordia curve at $109 \pm 22 \mathrm{Ma}$ and $1768 \pm 6 \mathrm{Ma}(\mathrm{MSWD}=1.6$; Fig. 8a). The upper intercept relies heavily on a nearly concordant borax-fusion analysis on monazite. The upper intercept age of the Nattanen sample A527 is $1789 \pm 5 \mathrm{Ma}(\mathrm{MSWD}=2.2)$, if one analysis with a high common $\mathrm{Pb}$ content is excluded. This result is, however, much dependent on analysis A527D2, which has been made from a zircon fraction leached in cold HF, and may thus be biased by unconstrained fractionation. This may also be the case with the two analyses from the Riestovaara (Roivanen) sample A417 (Fig. 8a). 
Based on these data we conclude that the age of the Nattanen-type magmatism south of the LGB is ca. $1775 \pm 10 \mathrm{Ma}$ in age. The best-fit age result for the Nattanen stock obtained from sample A173 is $1768 \pm 6 \mathrm{Ma}$. The amount of possible xenocrystic zircon within Nattanen-type granitoids is very limited.

\section{I.2.Vainospää batholith}

The U-Pb data on the Vainospää batholith (Fig. 1, 2) comprises 19 analyses on three samples (Table 3 ).
The analyzed zircon crystals are pale, euhedral, short, and simple prisms. The analyses show that the common $\mathrm{Pb}$ content is typically high and the results are very discordant (Fig. 8b). However, the two analyses on titanite give concordant $\mathrm{U}-\mathrm{Pb}$ results, yielding an age of $1775 \pm 7 \mathrm{Ma}$. The eleven analyses on sample A169 provide a chord that intercepts the concordia at $346 \pm 34 \mathrm{Ma}$ and $1784 \pm 20 \mathrm{Ma}$. The fairly high MSWD of 7.9 suggests some scatter due to geological processes or underestimation of analytical error. Using all nineteen $\mathrm{U}-\mathrm{Pb}$ analyses from samples
Fig. 8. Concordia diagrams for zircon, monazite, and titanite $\mathrm{U}$ $\mathrm{Pb}$ isotope data. a) the Nattanen stock. b) the Vainospää granite.
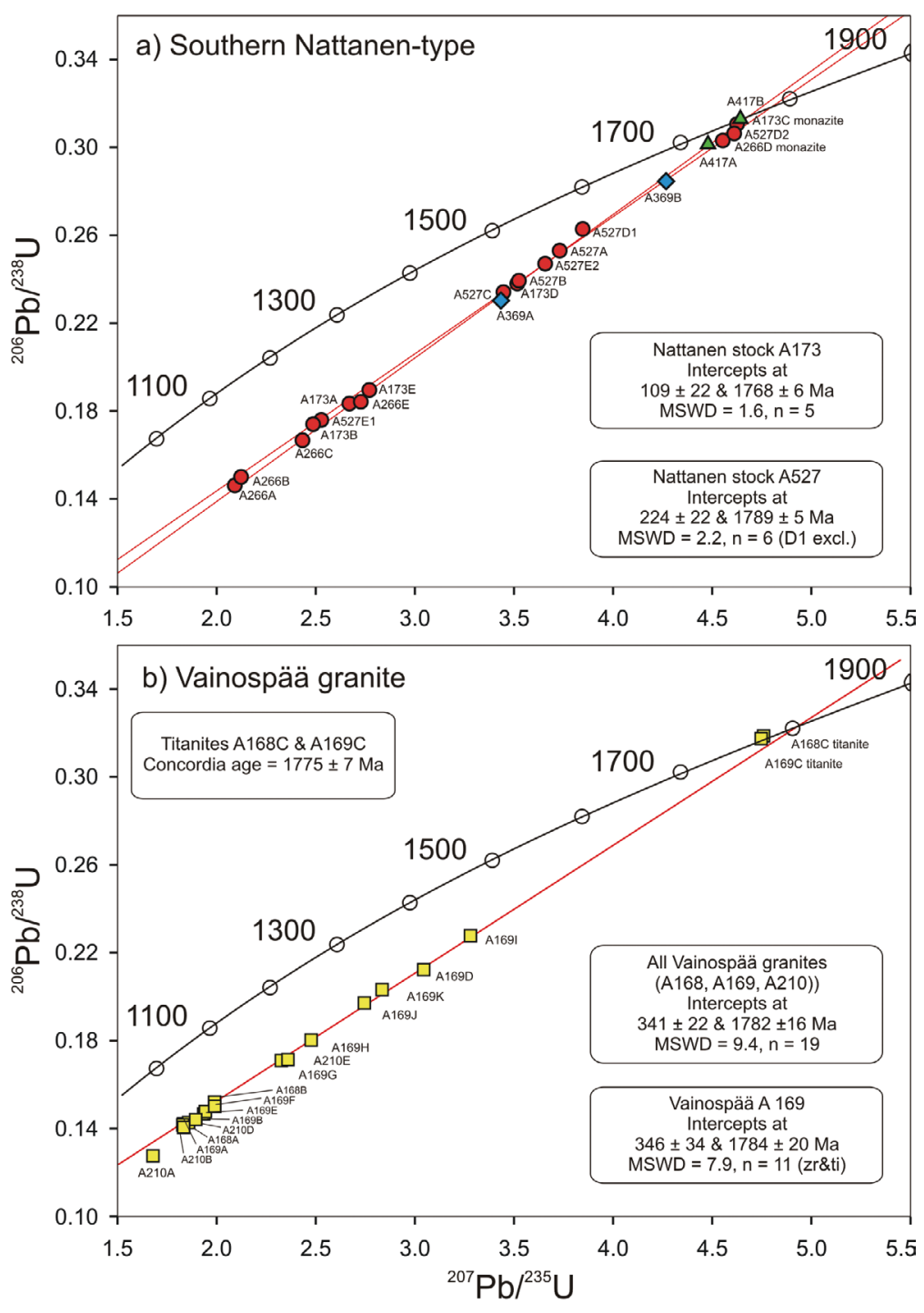
A168, A169, A210 the intercepts are $341 \pm 22 \mathrm{Ma}$ and $1782 \pm 16 \mathrm{Ma}(\mathrm{MSWD}=9.4$; Fig. 8e). From the concordant results obtained for magmatic titanites we conclude that the Vainospää granite crystallized at ca. $1775 \pm 7 \mathrm{Ma}$ and that it does not contain appreciable amounts of older xenocrystic zircon.

\section{2. $\mathrm{Pb}-\mathrm{Pb}$ results}

Lead isotope analyses on whole-rock and K-feldspar fractions were used to constrain the age and origin of the granites. These data are presented in Table 4 and in the ${ }^{207} \mathrm{~Pb} /{ }^{204} \mathrm{~Pb}$ vs. ${ }^{206} \mathrm{~Pb} /{ }^{204} \mathrm{~Pb}$ and ${ }^{208} \mathrm{~Pb} /{ }^{204} \mathrm{~Pb}$ vs. ${ }^{206} \mathrm{~Pb} /{ }^{204} \mathrm{~Pb}$ in Fig. 9. The diagrams show the twostage model of the evolution of crustal lead by Stacey and Kramers (1975) and selected model ratios from the plumbotectonic model of Zartman and Doe (1981).

The data on the Nattanen granites and porphyritic rhyolites (15 analyses on whole rocks, five on Kfeldspars) are scattered and do not provide a reliable isochron. Particularly, the most radiogenic analyses of the porphyritic rhyolites (Table 4) suggest late open system behavior and are thus not plotted in figures. For the Nattanen stock, an age of $1719 \pm 200$ Ma can be calculated from four whole-rocks and four K-feldspar analyses (Fig. 9a). The Pb isotope analyses on three whole rock- K-feldspar pairs from the Vainospää granite yield an age estimate of $1733 \pm 87$ Ma. The two analyses on whole rock and K-feldspar from the Tepasto granite $\mathrm{A} 184$ are consistent with the $\mathrm{U}-\mathrm{Pb}$ zircon age of ca. 1.8 Ga (Rastas et al., 2001).

Because $\mathrm{K}$-feldspar has a very low U/Pb-ratio and no major metamorphic episodes have affected the Nattanen-type granites since their crystallization, the measured $\mathrm{Pb}$ isotopic ratios can be viewed as a reasonable estimate of the initial isotopic composition of the granite. In the case of Nattanen this is relatively unradiogenic $\left({ }^{206} \mathrm{~Pb} /{ }^{204} \mathrm{~Pb}=14.58,{ }^{207} \mathrm{~Pb} /{ }^{204} \mathrm{~Pb}=14.85\right)$, particularly in terms of ${ }^{207} \mathrm{~Pb} /{ }^{204} \mathrm{~Pb}$. The data clearly show that the initial $\mathrm{Pb}$ isotope composition $(14.80,15.00)$ of the Vainospää granite is distinct from the Nattanen granite, but still relatively unradiogenic compared to average crustal lead at $1.7 \mathrm{Ga}$, which, according to the model by Stacey and Kramers (1975), has a ${ }^{206} \mathrm{~Pb} /{ }^{204} \mathrm{~Pb}$ of 15.57 and ${ }^{207} \mathrm{~Pb} /{ }^{204} \mathrm{~Pb}$ of 15.28 (S\&K $1.7 \mathrm{Ga}$ in Fig. 9a). The K-feldspar data plot slightly below (Nattanen) and above (Vainospää) the Zartman and Doe (1981) plumbotectonic model value for the unradiogenic lower crust at $1.8 \mathrm{Ga}$. The initial isotopic composition of Tepasto granite is more radiogenic than of Nattanen and Vainospää, but less radiogenic than the average terrestrial lead at $1.7 \mathrm{Ga}$. In the ${ }^{208} \mathrm{~Pb} /{ }^{204} \mathrm{~Pb}$ vs. ${ }^{206} \mathrm{~Pb} /{ }^{204} \mathrm{~Pb}$ diagram (Fig. 9b), K-feldspars from Nattanen and Vainospää plot near the Zartman and Doe (1981) lower crust value, which confirms the lower crustal lead isotope signature.

\section{Discussion}

\section{I. Geochemical classification}

A-type granites are considered to have crystallized from hot, restite-free and relatively anhydrous magmas (e.g. Loiselle \& Wones, 1979; Eby, 1990). Their conspicuous geochemical traits include high alkali abundances, $\mathrm{Fe} / \mathrm{Mg}, \mathrm{Ga} / \mathrm{Al}, \mathrm{Zr}, \mathrm{Nb}, \mathrm{Ga}$, and REE and a negative $\mathrm{Eu}$ anomaly. The abundances of $\mathrm{CaO}$, $\mathrm{MgO}, \mathrm{Sc}, \mathrm{Cr}, \mathrm{Ni}, \mathrm{Ba}, \mathrm{Sr}$, and $\mathrm{Eu}$ are generally low (op. cit.). A-type granites are most often connected to an extensional tectonic setting, although Whalen et al. (1987) demonstrated that A-type rocks are also found in active subduction zones and transcurrent regimes. Experimental studies suggest that A-type granite magmas may be generated by fluid-absent partial melting of intermediate-felsic rocks involving breakdown of halogen-rich mica and amphibole in mid- to lower crustal pressures and high temperatures (Creaser et al., 1991; Skjerlie \& Johnston, 1993). Thus the melting process and source composition may be more important in the genesis of A-type granites than the tectonic setting in which the granites have been emplaced.

The Nattanen-type granites are characterized by high $\mathrm{SiO}_{2}, \mathrm{Fe} / \mathrm{Mg}$, LREE, and high contents of incompatible elements $(\mathrm{K}, \mathrm{Rb}, \mathrm{Ba}, \mathrm{Th}, \mathrm{U})$. These features point to a crustal source with very little mantle involvement (Figs. 5, 6; Table 2; Appendix 1). This 
Table 4. $\mathrm{Pb}$ isotope data for Nattanen, Tepasto and Vainospää granites *.

\begin{tabular}{|c|c|c|c|c|c|c|c|c|}
\hline Sample & Location & $\begin{array}{l}\mathbf{W r} / \\
\mathbf{K f s}^{* *}\end{array}$ & $\begin{array}{l}{ }^{206} \mathrm{~Pb} / \\
{ }^{204} \mathrm{~Pb}\end{array}$ & $\begin{array}{l}{ }^{207} \mathrm{~Pb} / \\
{ }^{204} \mathrm{~Pb}\end{array}$ & $\begin{array}{l}{ }^{208} \mathrm{~Pb} / \\
{ }^{204} \mathrm{~Pb}\end{array}$ & $\boldsymbol{\mu}_{2}^{* * *}$ & $\begin{array}{l}\text { Coordinates } \\
\text { (WGS85) }\end{array}$ & \\
\hline \multicolumn{9}{|c|}{ Nattanen granite } \\
\hline A173 & Nattaset & wr & 18.61 & 15.28 & 41.31 & & $68^{\circ} 7^{\prime} 26.712^{\prime \prime} \mathrm{N}$ & $27^{\circ} 21^{\prime} 40.569^{\prime \prime} \mathrm{E}$ \\
\hline A173Kfs & Nattaset & $\mathrm{kfs}$ & 14.65 & 14.85 & 34.52 & 1.88 & $68^{\circ} 7^{\prime} 26.712^{\prime \prime} \mathrm{N}$ & $27^{\circ} 21^{\prime} 40.569^{\prime \prime} \mathrm{E}$ \\
\hline A266Kfs & Nattaset & wr & 14.58 & 14.83 & 34.48 & & $68^{\circ} 7^{\prime} 13.745^{\prime \prime} \mathrm{N}$ & $27^{\circ} 22^{\prime} 6.325^{\prime \prime} \mathrm{E}$ \\
\hline A349 & Salmurinvaara & wr & 24.51 & 15.83 & 48.59 & & $68^{\circ} 3^{\prime} 24.374^{\prime \prime} \mathrm{N}$ & $26^{\circ} 36^{\prime} 22.904^{\prime \prime} \mathrm{E}$ \\
\hline A350 & Lohijoki & wr & 18.78 & 15.33 & 41.71 & & $67^{\circ} 57^{\prime} 35.85^{\prime \prime} \mathrm{N}$ & $26^{\circ} 58^{\prime} 10.678^{\prime \prime} \mathrm{E}$ \\
\hline A351 & Salmurinvaara & wr & 21.30 & 15.44 & 45.71 & & $68^{\circ} 2^{\prime} 42.681^{\prime \prime} \mathrm{N}$ & $26^{\circ} 38^{\prime} 20.049^{\prime \prime} \mathrm{E}$ \\
\hline A527/10 & Nattaset & wr & 17.28 & 15.10 & 44.32 & & $68^{\circ} 6^{\prime} 23.456^{\prime \prime} \mathrm{N}$ & $27^{\circ} 23^{\prime} 57.944^{\prime \prime} \mathrm{E}$ \\
\hline A527/10Kfs & Nattaset & $\mathrm{kfs}$ & 14.58 & 14.84 & 34.39 & 1.93 & $68^{\circ} 6^{\prime} 23.456^{\prime \prime} \mathrm{N}$ & $27^{\circ} 23^{\prime} 57.944^{\prime \prime} \mathrm{E}$ \\
\hline A527/1 & Nattaset & wr & 17.89 & 15.19 & 43.20 & & $68^{\circ} 6^{\prime} 23.456^{\prime \prime} \mathrm{N}$ & $27^{\circ} 23^{\prime} 57.944^{\prime \prime} \mathrm{E}$ \\
\hline A527/12 & Nattaset & wr & 18.05 & 15.25 & 47.14 & & $68^{\circ} 6^{\prime} 23.456^{\prime \prime} \mathrm{N}$ & $27^{\circ} 23^{\prime} 57.944^{\prime \prime} \mathrm{E}$ \\
\hline A527/12Kfs & Nattaset & $\mathrm{kfs}$ & 14.56 & 14.87 & 34.49 & 1.93 & $68^{\circ} 6^{\prime} 23.456^{\prime \prime} \mathrm{N}$ & $27^{\circ} 23^{\prime} 57.944^{\prime \prime} \mathrm{E}$ \\
\hline
\end{tabular}

\section{Nattanen porphyric rhyolite dykes}

\begin{tabular}{|c|c|c|c|c|c|c|c|c|}
\hline A307 & Vuotso & wr & 21.98 & 15.57 & 45.44 & & $68^{\circ} 7^{\prime} 4.703^{\prime \prime} \mathrm{N}$ & $27^{\circ} 16^{\prime} 37.4^{\prime \prime} \mathrm{E}$ \\
\hline A307Kfs & Vuotso & $\mathrm{kfs}$ & 16.20 & 15.05 & 36.53 & 7.85 & $68^{\circ} 7^{\prime} 4.703^{\prime \prime} \mathrm{N}$ & $27^{\circ} 16^{\prime} 37.4^{\prime \prime} \mathrm{E}$ \\
\hline A345 & Hangasoja & wr & 28.87 & 16.29 & 63.97 & & & \\
\hline A346 & Tanka-aapa & $\mathrm{wr}$ & 23.62 & 15.86 & 49.11 & & & \\
\hline A347 & Jaurijoki & $\mathrm{wr}$ & 40.67 & 17.03 & 66.19 & & & \\
\hline A352 & Iisinkämppä & wr & 198.90 & 31.48 & 130.4 & & $68^{\circ} 7^{\prime} 23.149^{\prime \prime} \mathrm{N}$ & $26^{\circ} 19^{\prime} 21.954^{\prime \prime} \mathrm{E}$ \\
\hline A352/2 & Iisinkämppä & wr & 262.3 & 37.02 & 162.87 & & $68^{\circ} 7^{\prime} 23.149^{\prime \prime} \mathrm{N}$ & $26^{\circ} 19^{\prime} 21.954^{\prime \prime} \mathrm{E}$ \\
\hline A353 & Vuomaspää & wr & 16.72 & 15.14 & 38.53 & & & \\
\hline A354 & Ukselmapää & wr & 26.50 & 16.23 & 27.31 & & & \\
\hline
\end{tabular}

\section{Tepasto granite}

\begin{tabular}{l|l|l|l|l|l|l|l|l}
\hline A184 & Kotivaara & wr & 20.47 & 15.73 & 41.50 & & $67^{\circ} 59^{\prime} 55.873^{\prime \prime} \mathrm{N}$ & $24^{\circ} 40^{\prime} 27.253^{\prime \prime} \mathrm{E}$ \\
\hline A184Kfs & Kotivaara & kfs & 15.33 & 15.17 & 34.97 & 1.81 & $67^{\circ} 59^{\prime} 55.873^{\prime \prime} \mathrm{N}$ & $24^{\circ} 40^{\prime} 27.253^{\prime \prime} \mathrm{E}$ \\
\hline
\end{tabular}

\section{Vainospää granite}

\begin{tabular}{l|l|l|l|l|l|l|l|l}
\hline A168 & Vainospää & wr & 21.00 & 15.65 & 43.63 & & $69^{\circ} 32^{\prime} 6.656^{\prime \prime} \mathrm{N}$ & $28^{\circ} 39^{\prime} 49.136^{\prime \prime} \mathrm{E}$ \\
\hline A168Kfs & Vainospää & $\mathrm{kfs}$ & 14.81 & 14.99 & 34.87 & 1.98 & $69^{\circ} 32^{\prime} 6.656^{\prime \prime} \mathrm{N}$ & $28^{\circ} 39^{\prime} 49.136^{\prime \prime} \mathrm{E}$ \\
\hline A169 & Vainospää & $\mathrm{wr}$ & 20.05 & 15.55 & 41.92 & & $69^{\circ} 32^{\prime} 6.656^{\prime \prime} \mathrm{N}$ & $28^{\circ} 39^{\prime} 49.136^{\prime \prime} \mathrm{E}$ \\
\hline A169Kfs & Vainospää & $\mathrm{kfs}$ & 14.79 & 14.98 & 34.86 & 1.98 & $69^{\circ} 32^{\prime} 6.656^{\prime \prime} \mathrm{N}$ & $28^{\circ} 39^{\prime} 49.136^{\prime \prime} \mathrm{E}$ \\
\hline A210 & Päkkevaara & $\mathrm{wr}$ & 16.37 & 15.16 & 44.79 & & $69^{\circ} 33^{\prime} 39.338^{\prime \prime} \mathrm{N}$ & $29^{\circ} 4^{\prime} 11.673^{\prime \prime} \mathrm{E}$ \\
\hline A210Kfs & Päkkevaara & $\mathrm{kfs}$ & 14.82 & 15.01 & 34.91 & 2.01 & $69^{\circ} 33^{\prime} 39.338^{\prime \prime} \mathrm{N}$ & $29^{\circ} 4^{\prime} 11.673^{\prime \prime} \mathrm{E}$ \\
\hline
\end{tabular}

*) Analyses were made in early 1970s in isotope laboratory of Geological Survey of Finland (GTK), for methods see Vaasjoki (1977).

**) $\mathrm{wr}=$ whole rock fraction, $\mathrm{kfs}=\mathrm{K}$-feldspar fraction

***) After Stacey and Kramers (1975) two stage model

Isotopic ratios corrrected for fractionation using the CIT standard (Catanzaro, 1967), errors 0.2-0.3\%. 


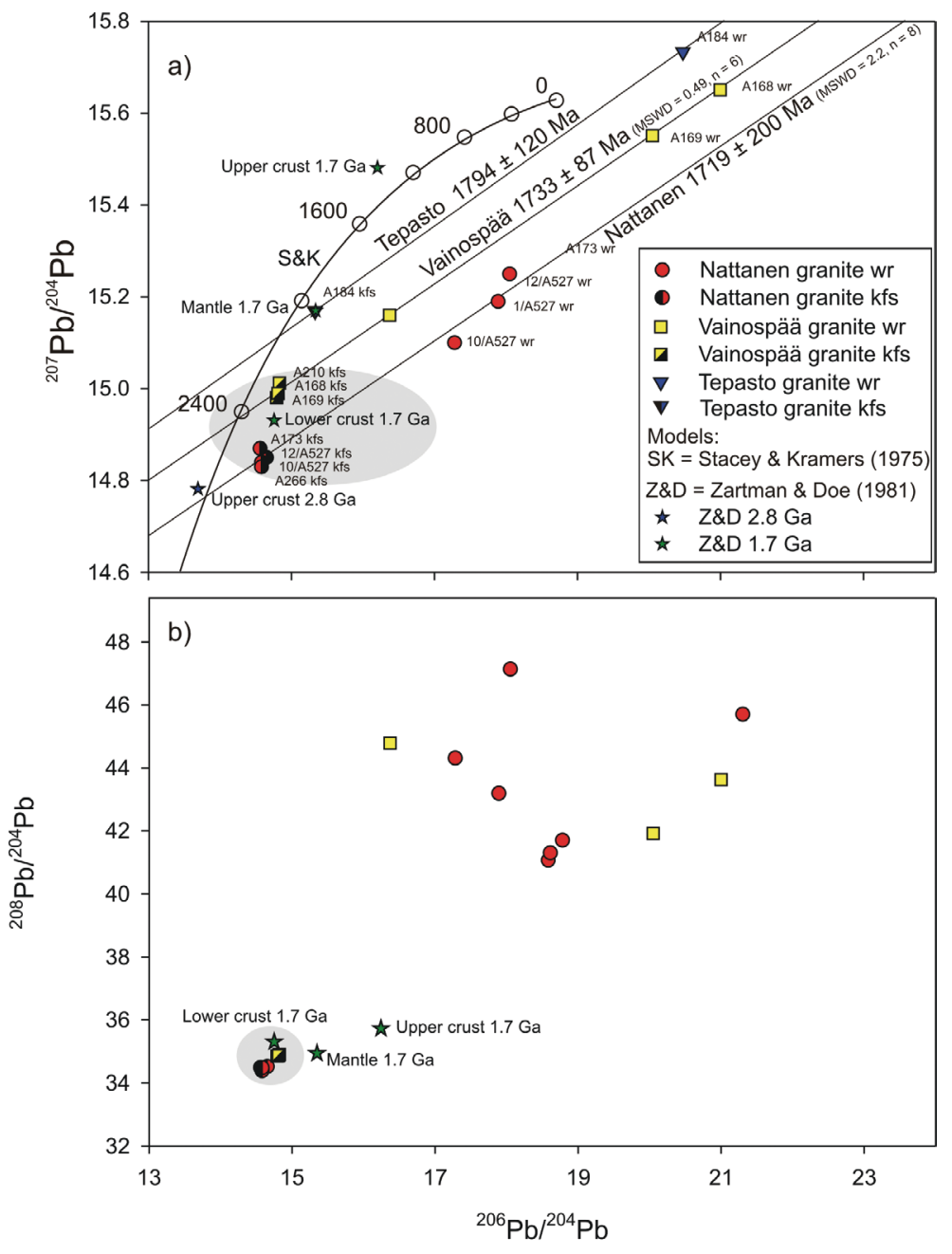

Fig. 9. $\mathrm{Kfs}=\mathrm{K}$-feldspar and $\mathrm{WR}=$ whole-rock $\mathrm{Pb}$ isotope composition of the Nattanen, Tepasto, and Vainospää granites. a) ${ }^{207} \mathrm{~Pb} /{ }^{204} \mathrm{~Pb}$ vs. ${ }^{206} \mathrm{~Pb} / 204 \mathrm{~Pb}$. b) ${ }^{208} \mathrm{~Pb} / 204 \mathrm{~Pb}$ vs. ${ }^{206} \mathrm{~Pb} /{ }^{204} \mathrm{~Pb}$. S\&K = evolution curve of the Stacey and Kramers (1975), Z\&D = represent mantle, upper crust, and lower crust at $1.7 \mathrm{Ga}$ and $2.8 \mathrm{Ga}$ after Zartman and Doe (198I) study shows that the Nattanen-type granites have a high Fe/Mg ratio typical for oxidized A-type granites. The rhyolite dykes from the Nattanen stock are more evolved and show reduced A-type characteristics (Fig. 6 c-f; Dall'Agnoll et al., 2007). The up-todate analyses further allow us to use the classification of Whalen et al. (1987) to confirm the A-type characteristics of the Nattanen-type granites. High $\mathrm{Zr}$ saturation temperatures and lack of significant inherited zircon in the Nattanen-type granites also point to an A-type character.

Geochemically, the Nattanen-type granites are similar to the 1.65-1.54 Ga anorogenic, reduced A-type rapakivi granites (e.g., Rämö \& Haapala, 2005), and the $-1.8 \mathrm{Ga}$ post-orogenic shoshonitic rocks (e.g., Andersson et al., 2006) of southern Finland. Some differences between these three granite groups can be observed, however. For example, in the tectonic classification of Pearce et al. (1984; Fig. 6b), the Nattanen-type granites and shoshonitic rocks differ from the rapakivi granites in their lower $\mathrm{Y}+\mathrm{Nb}$ values.

\subsection{Petrogenesis}

The $\mathrm{U}-\mathrm{Pb}$ isotopic age data (Table 3, Fig. 8) on zircon, monazite, and titanite indicate that the Nattanen-type granites south of the LGB and the Vainospää granite were emplaced at ca. $1.78 \mathrm{Ga}$. This is con- 
sistent with the 1.80-1.76 Ga ages earlier obtained for the Nattanen-type magmatism in the Fennoscadian shield (Vetrin et al., 2006; Rastas et al., 2001).

The whole-rock and $\mathrm{K}$-feldspar $\mathrm{Pb}$ isotope results (Table 4; Fig. 9) suggest that the source of the granites had resided in a relatively low $\mathrm{U} / \mathrm{Pb}$ environment such as Archean lower crust (Kouvo et al., 1983). The Nattanen and Vainospää K-feldspars plot close to the model $\mathrm{Pb}$ isotope ratios for the $1.8 \mathrm{Ga}$ lower crust after Zartman and Doe (1981). The Nattanen-type granitoids are slightly less radiogenic than the Vainospää granite. The K-feldspar data from the Nattanen and the Vainospää plutons are homogeneous implying that $\mathrm{Pb}$ was derived from well mixed source before incorporating into the crystallizing rock.

Figure 10 show isotopic variations compared to $\mathrm{SiO}_{2}$ compositions of the Nattanen, Vainospää, and Tepasto granites. The Nattanen granite shows the strongest crustal isotopic signatures, (least radiogenic initial Hf, $\mathrm{Nd}$ and uranogenic $\mathrm{Pb}$ isotopic composition) and the most evolved geochemical character. Experimental studies (Watkins et al., 2007) have shown that partial melting of hornblende-bearing (tonalitetrondhjemite-granodiorite) TTG in fluid-absent conditions is capable of producing small amounts of peraluminous granitic melts with high $\mathrm{SiO}_{2}$ and $\mathrm{K}_{2} \mathrm{O}$ / $\mathrm{Na}_{2} \mathrm{O}$ at the temperature of $<850{ }^{\circ} \mathrm{C}(0.8-1.2 \mathrm{MPa})$. $\mathrm{An}$ increase in the temperature produces larger vol- umes of melts of same granitic composition. Zircon saturation temperatures (Fig. 7) for the Nattanentype granites are in the $720-880^{\circ} \mathrm{C}$ range, which fits the experimental studies. The high temperatures may have caused melting or resetting of inherited zircons and homogenized $\mathrm{Pb}-\mathrm{Pb}$ isotope signatures. We suggest that the sources of the Nattanen granites are lower-crustal Archean hornblende-bearing TTG gneisses. High-T melting of low-radiogenic TTG source also explains the homogeneous $\mathrm{Pb}$ isotopic characteristics.

Our $\mathrm{Pb}$ isotope data are supported by previous Lu-Hf and Sm-Nd isotope studies. Patchett et al. (1981) reported less radiogenic initial $\varepsilon_{\mathrm{Hf}}$ values for the Nattanen granites $(-12.1)$ than for the Vainospää (-9.5) granites (Figs. 10b, 11b), and Huhma (1986) reported lower initial $\varepsilon_{\mathrm{Nd}}$ values for Nattanen (-9.1) than for Vainospää (-8.2; Figs. 10c; 11a). The highest $\varepsilon_{\mathrm{Nd}}$ value was reported for Tepasto (-5.7; Figs. op. cit.), which also shows the most radiogenic $\mathrm{Pb}$ isotope compositions (Fig. 9a; Fig 10 a), indicating a smaller proportion of Archean source component. The isotopic variation of the different Nattanen-type plutons may be the consequence of varying amounts and nature of source components (U/Pb, Lu/Hf and $\mathrm{Sm} / \mathrm{Nd}$ ratios and age). For example, Proterozoic metavolcanic rocks in the mainly Archean lower crust could account for the more juvenile character of the Tepas-
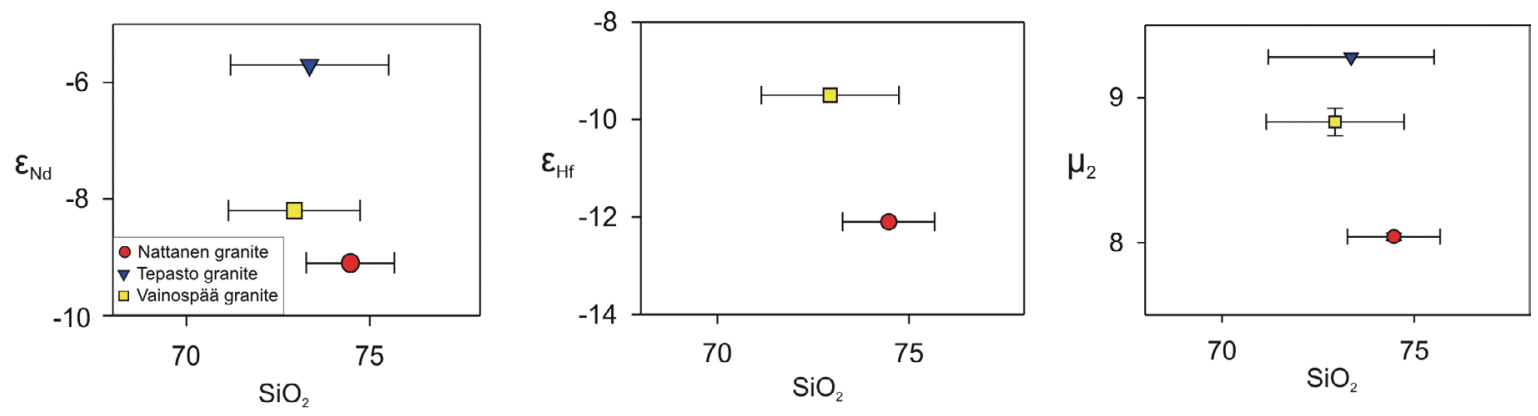

Fig. 10. Isotopic variation compared to average whole-rock composition showing differences of the Nattanen, Tepasto, and Vainospää granites, error bars are standard deviation $\sigma$. a) Two stage common lead $\mu_{2}$ (Stacey \& Kramers, 1975) vs. $\mathrm{SiO}_{2}$ b) $\varepsilon_{\mathrm{Hf}}$ vs. $\mathrm{SiO}_{2}$. c) $\varepsilon_{\mathrm{Nd}}$ vs. $\mathrm{SiO}_{2}$. 
to granite. This hypothesis is supported by the fact that this batholith is, at the present erosion level, surrounded by Proterozoic rocks (Fig. 1). In addition to different isotopic compositions, some samples of the Vainospää and Tepasto granite show calc-alkaline geochemical features and elevated $\mathrm{MgO}, \mathrm{CaO}$ and lower $\mathrm{SiO}_{2}$ than the Nattanen granite, which further implies lithological differences in the source rocks. In summary, the isotopic and geochemical characteristics of the Nattanen-type granites were probably derived from felsic Archean crustal sources $\left(\varepsilon_{\mathrm{Nd}}\right.$ ca. -13-- 10 and $\varepsilon_{\mathrm{Hf}}$ ca. -12.1--9.5) with minor contributions from younger source components, possibly Proterozoic crust $\left(\varepsilon_{\mathrm{Nd}}\right.$ ca. -2.5-4.0; Fig. 11a).

A petrogenetic model for the Nattanen-type granites needs to explain their widespread occurrence on both sides of the Kola-Karelia suture. The model should also account for the crustal source, highT melting conditions, and A-type geochemical character. Experimental studies on the melting of TTG gneisses in high- $\mathrm{T}$ conditions $\left(>850{ }^{\circ} \mathrm{C}\right.$ at $0.8-1.2$ $\mathrm{GPa}$ ) have produced granitic melts via the breakdown of amphibole after the exhaustion of biotite and muscovite at lower temperatures (e.g., Watkins et al., 2007 and references therein) that fits well with the isotopic data of the Nattanen-type granites. In here we discuss two plausible tectonic environments that may have produced Nattanen-type granites: extensional setting (e.g. Rämö \& Haapala, 2005), and melting of thickened orogenic crust (Vorma, 1976; Windley, 1991). In the case of extensional setting, mafic underplating is the most prominent mechanism and involves heating by mafic mantle derived magmatism and resulting partial melting in the crust, forming the parental magmas of the granites. Partial melting of the mantle may be related to rifting, extensional collapse of orogen, or deep mantle plumes (e.g., Haapala \& Rämö, 1999 and references therein). This model is supported by the FIRE 4 seismic reflector profile in Lapland that shows a strong reflection in lower crust (Patison et al., 2006). Similar reflections have been described related to the Finnish rapakivi granites and interpreted as stretching and underplating (Korja \& Heikkinen, 1995). This tectonic setting is often regarded as
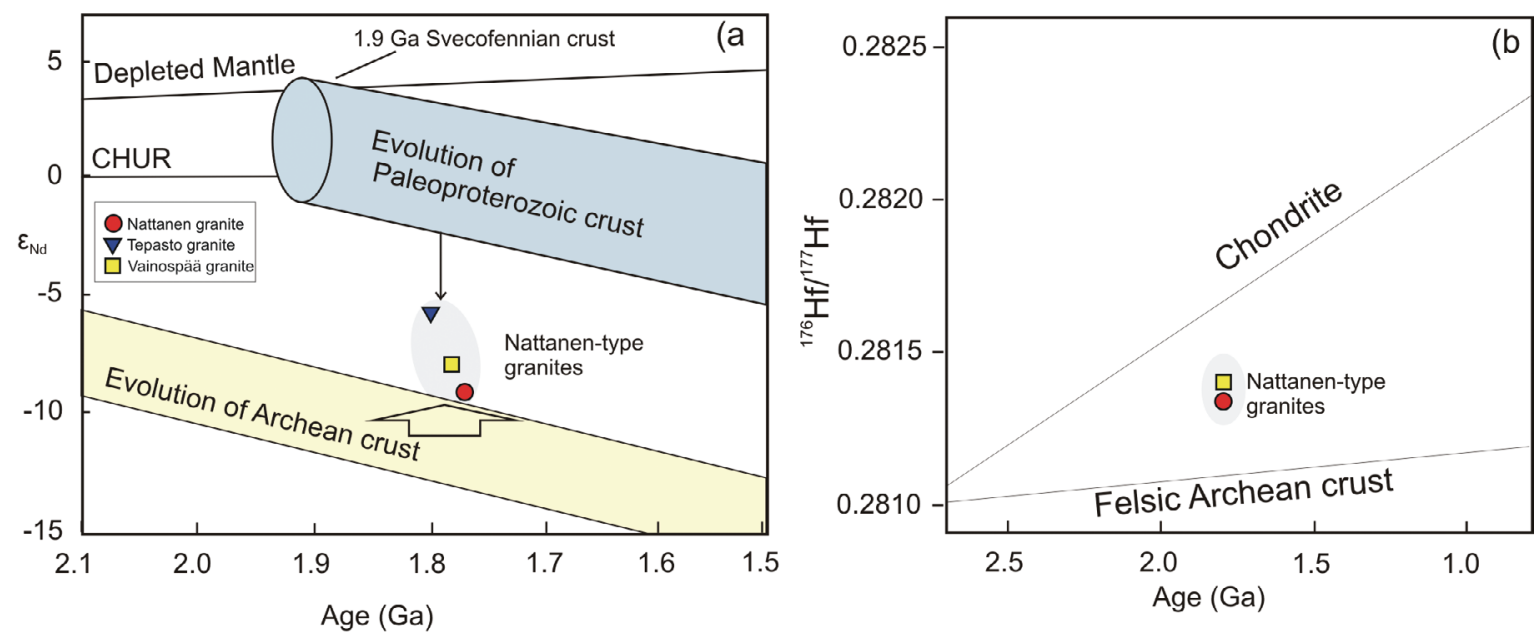

Fig. I I.a) An $\varepsilon_{\mathrm{Nd}}$ vs. age diagram illustrating the $\mathrm{Nd}$ isotope evolution of the Nattanen, Tepasto and Vainospää granites. Figure redrawn after Huhma (1986), depleted mantle after DePaolo (198I). b) An ${ }^{176} \mathrm{Hf} /{ }^{177} \mathrm{Hf}$ vs. age diagram illustrating the $\mathrm{Hf}$ isotope evolution of the Nattanen and Vainospää granites. Figure redrawn after Patchett et al. (198I). The diagrams show that Nattanen-type granites represent mainly remelted Archean crust, with possible minor contribution from Proterozoic crust. 
the regime of A-type granites, but the post-orogenic nature of the Nattanen-type granites (these rocks are partly coeval with orogenic granites of the CLGC; Ahtonen et al., (2007)) calls for also other regimes.

Another plausible tectonic environment, thickened orogenic crust, may have lead to thermal relaxation and is associated with increased radioactive heat production and normalization of the geothermal gradient, leading to high-T partial melting in stacked crust (e.g. Huerta et al., 1996; Vanderhaege \& Teyssier, 2001). A recent study on the thermal evolution of stacked crust in southern Finland suggested that the final products of crustal melting in thickened crust should be geochemically A-type, as higher temperatures are attained in the lower crust, allowing dehydration melting of amphibole to take place (Kukkonen \& Lauri, 2009). In the case of the Nattanen-type granites the partial melting of intermediate-felsic crust, involving dehydration break-down of amphibole during thermal relaxation in the lower part of thickened crust is a plausible mechanism for the petrogenesis of the granites, and explains also the lack of observations of coeval, mantle-derived mafic magmatism. The Nattanen-type granites may be geochemically classified as oxidized A-type granites derived from e.g. amphibole-bearing, halogen-enriched rocks of the lower crust, but their tectonic setting can obviously be explained in more than one way.

\subsection{Nattanen-type granites and tectonic evolution of the Fennoscandian shield}

The tectonic evolution of the Fennoscandian shield was characterized by 2.5-2.0 Ga extension-dominated period in the Early Paleoproterozoic (Vuollo \& Huhma, 2005 and references therein). After 2.0 Ga the dominant tectonic events were collisional and the shield grew rapidly by voluminous silicic magmatism that was coeval with the accretion of new terrains to the Archean craton. The collisional period between 1.9-1.8 Ga was a time for extensive crustal growth not only in the Fennoscandian shield but worldwide (e.g., Condie, 2000). The 1.9-1.8 Ga tectonic events have been assigned to the formation of a superconti- nent (Columbia) that consisted of at least Fennoscandia, Sarmatia, Laurentia, and Amazonia (e.g., Zhao et al., 2002).

The Nattanen-type granites have been considered as post-orogenic (Nironen et al., 2005) relative to the -1.9-1.8 Ga orogenic activity in Lapland caused by the collision of the Archean Norrbotten, Karelian, and Kola cratons (Lahtinen et al., 2005). Some of the deformed granites of the central Lapland granitoid complex have ages that are similar to or even younger than those of the Nattanen-type granites (Ahtonen et al., 2007), suggesting that the cessation of the collisional tectonics during the emplacement of the Nattanen-type granites was a more local phenomenon than previously thought and that the orogenic activity was not completely over in Lapland by $1.8 \mathrm{Ga}$.

The situation is similar in southern Finland, where minor shoshonitic post-orogenic granite magmatism (Eklund et al., 1998; Väisänen et al., 2000) was at least partly coeval with the voluminous Svecofennian late-orogenic collision-related leucogranite event between $1.85 \mathrm{Ga}$ and 1.79 Ga (Kurhila et al., 2005; Nironen \& Kurhila, 2008). The shoshonitic granites of southern Finland are geochemically similar to the Nattanen-type granites (Fig. 6) and the differences in the geochemistry of the two suites may be a consequence of different sources. The Nattanen-type granites were derived from a dominantly Archean lower crust whereas the shoshonitic rocks of southern Finland have a Paleoproterozoic lithospheric mantle source. Crustal-scale fracture zones in stabilized crust probably explain the locations of the post-orogenic intrusions in the northern and southern parts of the Fennoscandian shield.

\section{Conclusions}

1. Geochemically the Nattanen-type granites are oxidized, A-type granites and they were derived from a predominantly Archean lower crustal source. They are post-collisional, not anorogenic.

2. U-Pb isotopic age data support the notion that the Nattanen-type granites of Finland and Russia were formed as a consequence of a single magmatic event at $1.80-1.76 \mathrm{Ga}$. 
3. Whole-rock geochemical and isotope geological composition of the Nattanen-type granites suggests derivation mostly from Archean TTG gneisses, involving dehydration breakdown of amphibole. Minor compositional and isotopic differences between the Nattanen-type intrusions reflect varying proportions of different crustal materials in the source.

4. The formation of Nattanen-type granites can be explained at least in two ways:

A) Mafic underplating in an extensional setting may have caused high temperature partial melting in the overlying crust, forming the parental magmas of the Nattanen-type granites.

B) Postcollisional thermal relaxation, heat production, and stabilization of the geothermal gradient may have led to high temperatures in the thickened crust, and in the resultant formation of the parental magmas of the Nattanen-type granites.

5. In terms of tectonic evolution, the Nattanen-type granites represent the last magmatic event related to the Norbotten, Karelian, and Kola collision.

\section{Acknowledgements}

This paper is largely based on a long-term project carried out at the Isotope Laboratory of the Geological Survey of Finland (GTK). We are greatly indebted to Olavi Kouvo who graciously put his isotope data on the Finnish Nattanen-type granites at our disposal and delivered valuable comments on the manuscript. The thorough reviews by Ilmari Haapala and Mikko Nironen are acknowledged. Isotope sample preparation and data reduction were done by the staff of the isotope laboratory. Mirjam Ajlani is thanked for processing Fig. 2. Asko Käpyaho, Paula Kosunen, and Henrikki Rutanen are acknowledged for helping to gather data for the manuscript.

\section{References}

Ahtonen, N., Hölttä, P. \& Huhma, H., 2007. Intracratonic Palaeoproterozoic granitoids in nothern Finland: pro- longed and episodic crustal melting events revealed by $\mathrm{Nd}$ isotopes and $\mathrm{U}-\mathrm{Pb}$ ages on zircon. Bulletin of Geological Society of Finland 79, 143-174.

Andersson, U.B., Eklund, O., Fröjdö, S. \& Konopelko, D., 2006. 1.8 Ga magmatism in the Fennoscandian shield; lateral variations in subcontinental mantle enrichment. Lithos 86, 110-136.

Bergman, S., Kubler, L. \& Martinsson, O., 2001. Description of regional geological and geophysical maps of northern Norrbotten county (east of the Caledonian orogen), Sveriges Geologiska Undersökning. Ser. Ba. Översiktskartor med beskrivningar 56 .

Catanzaro, E.J., 1967. Absolute isotopic abundance ratios of three common lead reference samples. Earth Planetary Science Letters 3, 343-346.

Condie, K.C., 2000. Episodic continental growth models: After thought and extensions. Tectonophysics 322, 153-162.

Creaser, R.A., Price, R.C. \& Wormald, R.J., 1991. A-type granites revisited: assessment of a residual-source model. Geology 19, 163-166.

Dall'Agnol, R. \& de Oliveira, D.C., 2007. Oxidized, magnetite-series, rapakivi-type granites of Carajás, Brazil: Implications for classification and petrogenesis of A-type granites. Lithos 93, 215-233.

Daly, J.S., Balagansky, V.V., Timmerman, M.J., Whitehouse, M.J., de Jong, K., Guise, P., Bogdanova, S., Gorbatschev, R. \& Bridgwater, D., 2001. Ionmicroprobe U-Pb zircon geochronology and isotope evidence for a trans-crustal sututre zone in the Lapland - Kola Orogen, northern Fennosscandian shield. Precambrian Reseach 105, 289-314.

DePaolo, D.J., 1981. Neodymium isotopes in the Colorado Front Range and crist mantle evolution in Proterozoic. Nature 291, 684-196.

Eby, G.N., 1990. The A-type granitoids; a review of their occurrence and chemical characteristics and speculations on their petrogenesis. Lithos 26, 115-134.

Eklund, O., Konopelko, D., Rutanen, H., Fröjdö, S. \& Shebanov, A.D., 1998. 1.8 Ga Svecofennian post-collisional shoshonitic magmatism in the Fennoscandian Shield. Lithos 45, 87-108.

Elliott, B.A., 2001. The petrogenesis of the $1.88-1.87 \mathrm{Ga}$ post-kinematic granitoids of the central Finland granitoid complex. Ph.D. thesis, University of Helsinki, 36 p.

Elo, S., Lanne, E., Ruotoistenmäki, T. \& Sindre, A., 1989. Interpratations of gravity anomalies along the POLAR Profile in the northern Baltic Shield. Tectonophysics 162, $135-150$.

Front, K., Vaarma, M., Rantala, E. \& Luukkonen, A., 1989. Keski-Lapin varhaisproterotsooiset Nattas-tyypin graniittikompleksit, niiden kivilajit, geokemia ja mineralisaatiot. Summary: Early Proterozoic Nattanen-type granite complexes in central Finnish Lapland: rock types, geochemistry and mineralization. Geological Survey of Finland, Report of Investigation 85, 1-77. 
Frost, B.R., Barnes, C.G., Collins, W.J., Arculus, R.J., Ellis, D.J. \& Frost, C.D., 2001. A geochemical classification for granitic rocks. Journal of Petrology 42, 2033-2048.

Haapala, I. \& Rämö, O.T., 1999. Rapakivi granites and related rocks: an introduction. Precambrian Research 95, $1-7$.

Haapala, I., Front, K., Rantala, E. \& Vaarma, M., 1987. Petrology of Nattanen-type granite complexes, northern Finland. Precambrian Research 35, 225-240.

Hanski, E. \& Huhma, H., 2005. Central Lapland greenstonebelts. Archean rocks. In: Lehtinen, M., Nurmi, P.A. \& Rämö, O.T. (eds.) Precambrian Geology of Finland Key to the Evolution of the Fennoscandian shield. Developments in Precambrian Geology 14. Elsevier, Amsterdam, pp. 141-194.

Huerta A.D., Royden, L.H. \& Hodges, K.P., 1996. The Interpendence of Deformational and Thermal Processes in Mountain Belts. Science 273, 637-639.

Huhma, H., 1986. Sm-Nd, U-Pb and $\mathrm{Pb}-\mathrm{Pb}$ isotopic evidence for the origin of the Early Proterozoic Svecokarelian crust in Finland. Geological Survey Finland, Bulletin 337, 1-48.

Korsman, K., Koistinen, T., Kohonen, J., Wennerström, M., Ekdahl, E., Honkamo, M., Idman, H. \& Pekkala, Y., 1997. Bedrock map of Finland 1:1 000 000, Espoo. Geological Survey of Finland.

Kosunen, P., 1999. The rapakivi granite plutons of Bodom and Obbnäs, southern Finland: petrography and geochemistry. Bulletin of Geological Society of Finland 71, 275-304.

Korja, A. \& Heikkinen, P.J., 1995. Proterozoic extensional tectonics of the central Fennoscandian Shield: Results from the Baltic and Bothnian Echoes from the Lithosphere experiments. Tectonics 14, 504-517.

Kosunen, P.J., 2004. Petrogenesis of Mid-Proterozoic Atype granites: case studies from Fennoscandia (Finland) an Laurentia (New Mexico). Ph.D. thesis, University of Helsinki, 21 p.

Kouvo, O., Huhma, H. \& Sakko, M., 1983. Isotopic evidence for old crustal involvement in the genesis of two granites from northern Finland. Terra Cognita 3, 135.

Krogh, T.E., McNutt, R.H. \& Davis, G.L., 1982. Two high precision U-Pb zircon ages for the Sudbury Nickel Irruptive. Canadian Journal of Earth Sciences 19, 723-728.

Kukkonen, I.T. \& Lauri, L.S., 2009. Modelling the thermal evolution of a collisional Precambrian orogen: High heat production migmatitic granites of southern Finland. Precambrian Research 168, 233-246.

Kurhila, M., Vaasjoki, M., Mänttäri, I., Rämö, O.T. \& Nironen, M., 2005. U-Pb ages and $\mathrm{Nd}$ isotope characteristics of the lateorogenic, migmatizing microcline granites in southwestern Finland. Bulletin of the Geological Society of Finland 77, 105-128.

Lahtinen, R., Korja, A. \& Nironen, M., 2005. Paleoproterozoic tectonic evolution. In: Lehtinen, M., Nurmi, P.A. \& Rämö, O.T. (eds.) Precambrian Geology of Finland -
Key to the Evolution of the Fennoscandian shield. Developments in Precambrian Geology 14. Elsevier, Amsterdam, pp. 481-531.

Lehtiö, M., 1993. Nattas-tyypin graniittien raskasmineraalit. Phil. Lic. thesis, University of Helsinki, 117 p.

Lehtonen, M., Manninen. T., Rastas, P., Väänänen, J., Roos, S.I. \& Pelkonen, R., 1985. Keski-Lapin geologisen kartan selitys. Summary: Explanation to the geological map of Central Lapland. Geological Survey of Finland, Report of Investigation 71, 1-35.

Lehtonen, M., Airo, M.-L., Eilu, P., Hanski, E., Kortelainen, V., Lanne E., Manninen, T., Rastas, P., Räsänen, J. \& Virransalo, P., 1998. Kittilän vihreäkivialueen geologiaa, Lapin vulkaniitti projektin raportti. Summary: The stratigraphy, petrology and geochemistry of the Kittilä greenstone area, northern Finland, A report of the Lapland Volcanite Project. Geological Survey of Finland, Report of Investigation 140, 1-144.

Loiselle, M.C. \& Wones, D.R., 1979. Characteristics and origin of anorogenic granites. Geological Society of America, Absracts with Programs 7, 468.

Luukkonen, A., 1989. Sodankylän Nattastunturien graniittistokin petrografia, rakenne ja geokemia. Unpublished Mc.S. Thesis, University of Helsinki, 96 p.

Manninen, T., Pihlaja, P. \& Huhma, H., 2001. U-Pb geochronology of the Peurasuvanto area, northern Finland. In: Vaasjoki, M., Radiometric age determinations from Finnish Lapland and their bearing on the timing of Precambrian volcano-sedimentary sequences. Geological Survey of Finland, Special Paper 33, 189-200.

Meriläinen, K., 1976. The granulite complex and adjacent rocks in Lapland, northern Finland. Geological Survey of Finland, Bulletin 281, 1-129.

Mikkola, E., 1928. Über den Nattanengranit im finnischen Lapplande. Fennia 50, 1-22. (in German)

Mikkola, E., 1941. Suomen geologinen yleiskartta kartta 1:400 000: kallioperäkarttojen selitys lehdet B7-C7-D7 Muonia-Sodankylä-Tuntsajoki. Summary: The General geological map of Finland 1:400 000, explanations to the map of rocks B7-C7-D7 Muonia-Sodankylä-Tuntsajoki. Suomen geologinen toimikunta. 286 p.

Miller, C.F., Meschter McDowell, S. \& Mapes R.W., 2003. Hot and cold granites? Implications of zircon saturation temperatures and preservation of inheritance. Geology 31, 529-532.

Mutanen, T. \& Väänänen, J., 2004. PGE-Au-Cu-Ni potential of postkinematic appinitic $(1.79 \mathrm{Ga})$ intrusions in Finland. Julkaisussa: 17th Australian Geological Convention, Hobart 8-13 February 2004. Dynamic Earth: Past, present, and future. Abstracts. p. 104.

Nironen, M., 2005. Proterozoic orogenic granitoid rocks. Paleoproterozoic mafic dikes in NE Finland. In: Lehtinen, M., Nurmi, P.A. \& Rämö, O.T. (eds.) Precambrian Geology of Finland - Key to the Evolution of the Fennoscandian shield. Developments in Precambrian Geology 14. Elsevier, Amsterdam, pp. 443-479. 
Nironen, M. \& Mänttäri, I., 2003. Structural evolution of the Vuotso area, Finnish Lapland. Bulletin of the Geological Society of Finland 75, 93-101.

Nironen, M. \& Kurhila, M., 2008. The Veikkola granite area in southern Finland: emplacement of a $1.83-1.82 \mathrm{Ga}$ plutonic sequence in an extensional regime. Bulletin of the Geological Society of Finland 80, 39-68.

Pakkanen, L., 1993. Kittilän Tepaston graniittikompleksin petrografia, petrofysiikka, geokemia ja Mo-Cu-mineralisaatio. Unpublished Mc.S. Thesis, University of Helsinki, 82 p.

Patison, N.L., Korja, A., Lahtinen., Ojala V.J. \& the FIRE Working GROUP, 2006. FIRE seismic reflection profiles 4, $4 \mathrm{~A}$ and $4 \mathrm{~B}$ insights into the crustal structure of northern Finland from Ranua to Näätämö. Geological Survey of Finland, Special Paper 43, 161-222.

Patchett, J., Kouvo, O., Hedge, C. \& Tatsumoto, M., 1981. Evolution of continental crust and mantle heterogeneity: evidence from Hf isotopes. Contributions to Mineralogy and Petrology 78, 279-297.

Pearce, J., 1996. Sources and setting of granitic rocks. Episodes $19,120-125$.

Pearce, J.A., Harris, N.B.W. \& Tindle, A.G., 1984. Trace element discrimination diagrams for the tectonic interpretations of the granitic rocks. Journal of Petrology 25, 956-983.

Rämö, O.T., 1991. Petrogenesis of the Proterozoic rapakivi granites and related basic rocks of southeastern Fennoscandia: $\mathrm{Nd}$ and $\mathrm{Pb}$ isotopic and general geochemical constraints. Geological Survey of Finland, Bulletin 355, $1-161$.

Rämö, O.T. \& Haapala, I., 2005. Rapakivi granites. In: Lehtinen, M., Nurmi, P.A. \& Rämö, O.T., (eds.) Precambrian Geology of Finland - Key to the Evolution of the Fennoscandian shield. Developments in Precambrian Geology 14. Elsevier, Amsterdam, pp. 553-562.

Rasilainen, K., Lahtinen, R. \& Bornhorst, T.J., 2007. The Rock Geochemical Database of Finland Manual. Geological Survey of Finland, Report of Investigation 164, $1-38$.

Rastas, P., Huhma, H., Hanski, E., Lehtonen, M.I, Härkönen, I., Kortelainen, V., Mänttäri, I. \& Paakkola, J.I., 2001. U-Pb isotopic studies on the Kittilä greenstone area, central Lapland, Finland. In: Vaasjoki, M. (ed.) Radiometric age determinations from Finnish Lapland and their bearing on the timing of Precambrian volcano-sedimentary sequences. Geological Survey of Finland, Special Paper 33, 95-141.

Rieder, M., Haapala, I. \& Povondra P., 1996. Mineralogy of dark mica from the Wiborg rapakivi batholith, southeastern Finland. European Journal of Mineralogy $8,593-605$.

The Rock Geochemical Database of Finland (online database). Version 1.0. Espoo: Geological Survey of Finland, 30.3.2007. Accessed: 03.06.2007. Available: http://www. gtk.fi/publ/RGDB
Rutanen, H., Eklund, O. \& Konopelko, D., 1997. Rock and mineral analyses of Svecofennian postorogenic 1.8 Ga intrusions in southern Finland and Russian Karelia. Geocenter raportti - geocenter raport, Åbo Akademi University, 8 p.

Skjerlie, K.P. \& Johnston, A.D., 1993. Fluid-absent melting behavior of an F-rich tonalitic gneiss at mid-crustal pressures: implications for the generation of anorogenic granites. Journal of Petrology 34, 785-815.

Stacey, J.S. \& Kramers, J.D., 1975. Approximation of terrestrial lead isotope evolution by a two-stage model. Earth Planetary Science Letters 26, 207-221.

Sun, S.S. \& McDonough, W.F., 1989. Chemical and isotopic systematic of oceanic basalts: Implications for mantle composition and processes. In: Saunders, A.D. \& Norry, M.J. (eds.) Magmatism, in Ocean basins. Geological Society of London, Special Publication 42, 313-345.

Tuisku, P. \& Huhma, H., 2006. Evolution of migmatitic granulite complexes: implications from Lapland Granulite Belt, Part II: isotopic dating. Bulletin of the Geological Society of Finland 78, 143-175.

Tuisku, P., Mikkola, P. \& Huhma, H., 2006. Evolution of migmatitic granulite complexes: implications from Lapland Granulite Belt, Part 1: metamorphic geology. Bulletin of the Geological Society of Finland 78, 71-105.

Vaasjoki, M., 1977. Rapakivi granites and other postorogenic rocks in Finland: their age and the lead isotopic composition of certain associated galena mineralizations. Geological Survey of Finland, Bulletin 294, 1-64.

Vaasjoki, M., (ed.) 2001. Radiometric age determinations from Finnish Lapland and their bearing on the timing of Precambrian volcano-sedimentary sequences. Geological Survey of Finland, Special Paper 33, 1-279.

Väisänen, M., Mänttäri, I., Kriegsman, L.M. \& Hölttä, P., 2000. Tectonic setting of post-collisional magmatism in the Palaeoproterozoic Svecofennian orogen, SW Finland. Lithos 54, 63-81.

Vanderhaege, O. \& Teyssier, C., 2001. Partial melting and flows of orogens. Tectonophysics 342, 451-472.

Vetrin, V.R., Vinogradov, A.N. \& Vinogradov, G.V., 1975. Petrologiya I fatsialno-formatsionnyi analiz litskoaragubskogo diorite-granitnogo kompleksa. In: Batieve, I.D. (ed.) Intruzivnye Crarnokity I Porfirovidnye Granity Kolskogo Poluostrova. Nauka, Apatity, 149-316. (in Russian)

Vetrin, V.R., Berezhnaya, N.G. \& Rodionov, N.V., 2006. Petrology of Postorogenic Granitoids of the Northern Baltic Shield. Doklady Earth Sciences, 411A, No 9, 1476-1479.

Vorma, O., 1976. On the petrochemistry of rapakivi granites with special reference to the Laitila massif, southwestern Finland. Geological Survey of Finland, Bulletin $272,1-98$.

Vuollo, J. \& Huhma, H., 2005. Paleoproterozoic mafic dikes in NE Finland. In: Lehtinen, M., Nurmi, P.A. \& Rämö, O.T. (eds.) Precambrian Geology of Finland - Key 
to the Evolution of the Fennoscandian shield. Developments in Precambrian Geology 14. Elsevier, Amsterdam, pp. 195-236.

Watkins, J.M., Clemens J.D. \& Treloar, P.J., 2007. Archean TTGs as sources of younger granitic magmas: melting of sodic metatonalites at 0.6-1.2 GPa. Contributions to Mineralogy and Petrology 154, 91-110.

Watson, E.P.B. \& Harrison, T.M., 1983. Zircon saturation revisited: temperature and composition effects in a variety of crustal magma types. Earth and Planetary Science Letters 64, 295-304.

Wennerström, M. \& Airo, M.-L., 1998. Magnetic fabric and emplacement of the post-collisional Pomovaara Granite Complex in northern Fennoscandia. Lithos 45, 131145.

Whalen, J.B., Currie, K.L. \& Chappell, B.W., 1987. A-type granites: geochemical characteristics, discrimination and petrogenesis. Contributions to Mineralogy and Petrology 95, 407-419.

White, A.J.R. \& Chappell, B.W., 1983. Granioid types and their distributions in the Lachlan Fold Belt, southeastern Australia. In: Roddick, J.A. (ed.) Circum-Pacific Plutons Terraines. Geological Society of America, Memoirs 159, 21-34.

Windley, B.F., 1991. Early Proterozoic collision tectonics, and rapakivi granites as intrusions in an extensional thrust-thickened crust: the Ketilidian orogen, South Greenland. Tectonophysics 195, 1-10.

Zartman, R.E. \& Doe, B.R., 1981. Plumbotectonics - the model. Tectonophysics 75, 135-162.

Zhao, G., Cawood, P.A., Wilde, A.S. \& Sun, M., 2002. Review of global 2.1-1.8 Ga orogens: implications for a pre-Rodinia supercontinent. Earth-Science Reviews 59, 125-162. 


\section{Appendix I. Compiled dataset of previously published whole-rock elemental analyses from granitic samples} from Nattanen-type intrusions.

\begin{tabular}{|c|c|c|c|c|c|c|c|c|c|c|c|c|}
\hline Intrusion & Nattanen & Nattanen & Nattanen & Pomovaara & Pomovaara & Pomovaara & Pomovaara & Pomovaara & Riestovaara & Riestovaara & Riestovaara & Riestovaara \\
\hline Sample & 92009679 & 92009683 & 92009691 & 92009552 & 92009555 & 92009559 & 92009561 & 92009629 & 92009672 & 92009569 & 92009705 & 92009544 \\
\hline TiO2 wt. $\%$ & 0.19 & 0.17 & 0.17 & 0.20 & 0.04 & 0.34 & 0.43 & 0.12 & 0.21 & 0.30 & 0.04 & 0.38 \\
\hline Al2O3 wt. $\%$ & 13.20 & 13.30 & 13.20 & 14.20 & 13.90 & 13.60 & 13.00 & 12.80 & 13.10 & 13.40 & 13.30 & 14.40 \\
\hline FeOt wt. $\%$ & 1.35 & 1.20 & 1.31 & 1.42 & 0.63 & 2.09 & 3.26 & 0.92 & 1.24 & 1.64 & 0.42 & 2.14 \\
\hline $\mathrm{MgO}$ wt. $\%$ & 0.18 & 0.14 & 0.46 & 0.33 & 0.01 & 0.50 & 0.74 & 0.10 & 0.20 & 0.31 & 0.02 & 0.76 \\
\hline $\mathrm{CaO}$ wt. $\%$ & 0.69 & 0.66 & 0.78 & 1.26 & 0.76 & 1.53 & 1.17 & 0.64 & 0.79 & 0.90 & 0.67 & 1.20 \\
\hline $\mathrm{Na} 2 \mathrm{O}$ wt. $\%$ & 3.74 & 3.77 & 3.67 & 3.91 & 4.34 & 3.66 & 3.52 & 3.76 & 3.67 & 3.50 & 4.73 & 3.69 \\
\hline K2O wt.\% & 4.82 & 4.83 & 4.72 & 4.47 & 4.44 & 4.27 & 3.87 & 4.48 & 4.68 & 5.17 & 3.83 & 4.77 \\
\hline P2O5 wt.\% & 0.02 & 0.02 & 0.02 & 0.06 & 0.00 & 0.11 & 0.14 & 0.01 & 0.03 & 0.04 & 0.00 & 0.11 \\
\hline Cu_175x ppm & $<20$ & $<20$ & $<20$ & $<20$ & $<20$ & $<20$ & $<20$ & $<20$ & $<20$ & $<20$ & $<20$ & $<20$ \\
\hline Ga_175x ppm & 30 & 28.3 & 28.7 & 25 & 29.6 & 30.8 & 29.2 & 33.1 & 27.7 & 24.8 & 19 & 38.8 \\
\hline Mo_175x ppm & $<10$ & $<10$ & $<10$ & $<10$ & $<10$ & $<10$ & $<10$ & $<10$ & $<10$ & $<10$ & $<10$ & $<10$ \\
\hline Nb_175x ppm & 22.1 & 20.1 & 20.2 & 22.7 & 17.4 & 18.5 & 39.4 & 16.6 & 17.4 & 24.6 & 34.2 & 17.6 \\
\hline Ni_175x ppm & $<20$ & $<20$ & 22.7 & $<20$ & $<20$ & $<20$ & $<20$ & $<20$ & $<20$ & $<20$ & $<20$ & $<20$ \\
\hline Pb_175x ppm & $<30$ & 30.4 & 32 & 41.8 & 48.8 & 34.7 & 39.7 & 38.6 & $<30$ & $<30$ & 42.9 & $<30$ \\
\hline Rb_175x ppm & 178 & 194 & 191 & 206 & 244 & 170 & 269 & 275 & 211 & 180 & 331 & 154 \\
\hline$\underline{S \_175 x \mathrm{ppm}}$ & $<100$ & $<100$ & $<100$ & $<100$ & $<100$ & $<100$ & $<100$ & $<100$ & $<100$ & $<100$ & $<100$ & $<100$ \\
\hline Sc_175x ppm & $<30$ & $<30$ & $<30$ & $<30$ & $<30$ & $<30$ & $<30$ & $<30$ & $<30$ & $<30$ & $<30$ & $<30$ \\
\hline B_511p ppm & $<5$ & $<5$ & $<5$ & $<5$ & $<5$ & $<5$ & $<5$ & $<5$ & $<5$ & $<5$ & $<5$ & $<5$ \\
\hline Ba_511p ppm & 31.6 & 35.8 & 41.7 & 44.3 & 16.2 & 77.4 & 72.3 & 18.5 & 39.4 & 57.4 & 14.5 & 79 \\
\hline Be_511p ppm & $<0.5$ & $<0.6$ & $<0.7$ & $<0.8$ & $<0.9$ & $<0.10$ & $<0.11$ & $<0.12$ & $<0.13$ & $<0.14$ & $<0.15$ & $<0.16$ \\
\hline Ca_511p ppm & 1960 & 1400 & 1120 & 2240 & 582 & 2660 & 2110 & 1000 & 2030 & 1780 & 1260 & 2460 \\
\hline Cd_511p ppm & $<1$ & $<1$ & $<1$ & $<1$ & $<1$ & $<1$ & $<1$ & $<1$ & $<1$ & $<1$ & $<1$ & $<1$ \\
\hline Co_511p ppm & $<1$ & $<1$ & 1.81 & 2.68 & $<1$ & 4.9 & 6.27 & 1.16 & 1.48 & 1.98 & $<1$ & 5.96 \\
\hline Cr_511p ppm & 2.99 & 2.97 & 14.4 & 9.94 & 3.37 & 8.72 & 12.3 & 3.44 & 3.00 & 7.46 & 2.48 & 8.09 \\
\hline Cu_511p ppm & 1.8 & 1.97 & 3.03 & 3.94 & 4.14 & 8.98 & 10.1 & 3.36 & 2.08 & 2.5 & 2.92 & 7.67 \\
\hline Fe_511p ppm & 13400 & 12000 & 11500 & 14500 & 6150 & 21000 & 29800 & 10000 & 12300 & 16700 & 4080 & 22100 \\
\hline K_511p ppm & 1600 & 2170 & 1930 & 1840 & 863 & 3580 & 4420 & 1050 & 1220 & 2020 & 909 & 3040 \\
\hline La_511p ppm & 115 & 54.6 & 60.6 & 69.3 & 7.5 & 89.6 & 87.6 & 52 & 97.3 & 148 & 14.1 & 94.5 \\
\hline Li_511p ppm & 8.49 & 18.5 & 20.9 & 28.2 & 1.63 & 17.3 & 72.9 & 5.78 & 11.1 & 12.9 & 1.31 & 22.9 \\
\hline Mg_511p ppm & 1210 & 1190 & 1670 & 1820 & 151 & 3290 & 4260 & 797 & 1350 & 1770 & 254 & 4770 \\
\hline Mn_511p ppm & 99.3 & 95.9 & 157 & 340 & 150 & 327 & 413 & 130 & 171 & 150 & 76.4 & 262 \\
\hline Mo_511p ppm & $<5$ & $<5$ & $<5$ & $<5$ & $<5$ & $<5$ & $<5$ & $<5$ & $<5$ & $<5$ & $<5$ & $<5$ \\
\hline
\end{tabular}




\begin{tabular}{|c|c|c|c|c|c|c|c|c|c|c|c|c|}
\hline Tepasto & Vainospää & Vainospää & Vainospää & Vainospää & Vainospää & Vainospää & Vainospää & Vainospää & Vainospää & Vainospää & Vainospää & Vainospää \\
\hline 93001676 & 95001306 & 95001302 & 91011354 & 91011362 & 91011365 & 91011367 & 91011369 & 95001281 & 95001282 & 95001283 & 95001307 & 95001308 \\
\hline 70.7 & \begin{tabular}{|l|}
72.7 \\
\end{tabular} & 74.9 & \begin{tabular}{|l|}
74.0 \\
\end{tabular} & 74.6 & 74.0 & 73.5 & 73.1 & 73.7 & 70.5 & 70.5 & \begin{tabular}{|l|}
69.5 \\
\end{tabular} & 74.3 \\
\hline 0.30 & 0.31 & 0.13 & 0.14 & 0.11 & 0.13 & 0.18 & 0.20 & 0.194 & 0.34 & 0.41 & 0.44 & 0.14 \\
\hline 15.20 & 14.00 & 13.70 & 13.80 & 13.70 & 13.70 & 13.50 & 14.80 & 13.90 & 15.10 & 14.60 & 14.80 & 13.50 \\
\hline 1.90 & 2.19 & 1.01 & 1.42 & 1.20 & 1.47 & 2.22 & 1.23 & 1.57 & 2.29 & 2.36 & 3.04 & 1.53 \\
\hline 0.03 & 0.02 & 0.03 & 0.04 & 0.03 & 0.04 & 0.02 & 0.02 & 0.03 & 0.04 & 0.03 & 0.05 & 0.01 \\
\hline 0.56 & 0.58 & 0.19 & 0.19 & 0.19 & 0.20 & 0.69 & 0.32 & 0.45 & 0.63 & 0.66 & 0.70 & 0.16 \\
\hline 1.51 & 0.79 & 1.38 & 1.11 & 1.02 & 1.12 & 0.21 & 1.40 & 0.89 & 1.85 & 1.64 & 1.72 & 1.26 \\
\hline 4.23 & 3.62 & 3.86 & 3.46 & 3.42 & 3.41 & 3.60 & 4.50 & 3.85 & 4.18 & 4.31 & 3.78 & 3.63 \\
\hline 4.87 & 5.07 & 4.32 & 5.40 & 5.38 & 5.48 & 5.49 & 4.02 & 4.83 & 4.32 & 4.49 & 4.98 & 4.81 \\
\hline 0.13 & 0.09 & 0.03 & 0.04 & 0.03 & 0.04 & 0.05 & 0.06 & 0.05 & 0.11 & 0.17 & 0.14 & 0.03 \\
\hline 1068 & 1343 & 519 & 659 & 501 & 625 & 811 & 669 & 710 & 1223 & 1932 & 1540 & 1375 \\
\hline$<100$ & 130 & $<100$ & $<100$ & $<100$ & $<100$ & $<100$ & $<100$ & $<100$ & 110 & 120 & 280 & $<100$ \\
\hline$<30$ & $<30$ & $<30$ & $<30$ & $<30$ & $<30$ & $<30$ & $<30$ & $<30$ & $<30$ & $<30$ & $<30$ & $<30$ \\
\hline$<20$ & $<20$ & $<20$ & $<20$ & $<20$ & $<20$ & $<20$ & $<20$ & $<20$ & $<20$ & $<20$ & $<20$ & $<20$ \\
\hline 25.9 & 27 & 26 & 29 & 27.1 & 21 & 25.3 & 22.2 & 26.1 & 26 & 69 & 30 & 29 \\
\hline$<10$ & $<10$ & $<10$ & $<10$ & $<10$ & $<10$ & $<10$ & $<10$ & $<10$ & $<10$ & $<10$ & $<10$ & $<10$ \\
\hline$<10$ & 13 & $<10$ & 14.3 & $<10$ & 13.3 & 10.9 & $<10$ & 14 & 18 & 14 & 28 & $<10$ \\
\hline$<20$ & $<20$ & $<20$ & $<20$ & $<20$ & $<20$ & $<20$ & $<20$ & $<20$ & $<20$ & $<20$ & $<20$ & $<20$ \\
\hline$<30$ & 36 & 58 & 58.6 & 62.8 & 67.1 & 38.2 & 37.4 & 41 & 47 & 36 & 48 & 41 \\
\hline 173 & 164 & 197 & 274 & 252 & 251 & 197 & 115 & 242 & 184 & 152 & 246 & 150 \\
\hline$<100$ & $<100$ & $<100$ & $<100$ & $<100$ & $<100$ & $<100$ & $<100$ & $<100$ & $<100$ & 210 & 120 & $<100$ \\
\hline$<30$ & $<30$ & $<30$ & $<30$ & $<30$ & $<30$ & $<30$ & $<30$ & $<30$ & $<30$ & $<30$ & $<30$ & $<30$ \\
\hline$<30$ & $<30$ & $<30$ & $<30$ & $<30$ & $<30$ & $<30$ & $<30$ & $<30$ & $<30$ & $<30$ & $<30$ & $<30$ \\
\hline 250 & 239 & 146 & 133 & 114 & 129 & 87.5 & 231 & 126 & 281 & 474 & 224 & 332 \\
\hline 33 & 35 & $<30$ & $<30$ & $<30$ & $<30$ & $<30$ & $<30$ & $<30$ & 44 & 44 & 45 & $<30$ \\
\hline 12 & 12 & $<10$ & 24.3 & 17.5 & 22.2 & 18 & $<10$ & $<10$ & 17 & $<10$ & 18 & $<10$ \\
\hline 34 & 23 & 28 & 50 & 44.9 & 47.2 & 33.4 & 50.7 & 30 & 46 & 22 & 78 & $<20$ \\
\hline 186 & 248 & 129 & 160 & 130 & 147 & 195 & 154 & 181 & 289 & 291 & 401 & 115 \\
\hline 5600 & 5000 & 4000 & 5380 & 4910 & 5980 & 6240 & 5170 & 5400 & 8100 & 5200 & 10000 & 2600 \\
\hline$<5$ & $<5$ & $<5$ & $<<5$ & $<<5$ & $<5$ & $<<5$ & $<<5$ & $<<5$ & $<5$ & $<5$ & $<5$ & $<5$ \\
\hline 58.5 & 29 & 23.2 & 26.7 & 15.8 & 23 & 19.9 & 25.5 & 30.5 & 87.5 & 45.1 & 133 & 54.7 \\
\hline$<0.17$ & $<0.18$ & $<0.19$ & $<1$ & $<1$ & $<1$ & $<1$ & $<1$ & 0.6 & $<0.5$ & $<0.6$ & $<0.7$ & $<0.8$ \\
\hline 2600 & 1200 & 1500 & 2010 & 1840 & 2050 & 801 & 1410 & 2000 & 4800 & 5500 & 4900 & 1800 \\
\hline$<1$ & $<1$ & $<1$ & $<1$ & $<1$ & $<1$ & $<1$ & $<1$ & $<1$ & $<1$ & $<1$ & $<1$ & $<1$ \\
\hline 4.8 & 4.3 & 1.9 & 2.13 & 1.86 & 2.62 & 5.22 & 3.08 & 2.6 & 5.1 & 5.9 & 5.8 & 1.9 \\
\hline 7.30 & 6.90 & 4.70 & 4.00 & 5.08 & 5.63 & 4.64 & 4.65 & 5.50 & 7.60 & 12.20 & 13.10 & 3.60 \\
\hline 9.1 & 9.9 & 2.9 & 3.31 & 3.87 & 3.7 & 4.08 & 5.09 & 2.6 & 6.4 & 3.6 & 9.5 & 2.5 \\
\hline 18700 & 17600 & 9800 & 12600 & 11600 & 14700 & 19400 & 11900 & 13600 & 21000 & 22100 & 26600 & 13900 \\
\hline 4100 & 800 & 2000 & 2490 & 1850 & 2920 & 899 & 2230 & 900 & 3100 & 800 & 5900 & 1000 \\
\hline 46.1 & 68.9 & 44.5 & 65.6 & 39.5 & 70.2 & 33.2 & 28.6 & 60.6 & 115 & 121 & 164 & 42.3 \\
\hline 36.9 & 8.5 & 18.8 & 46.8 & 10.5 & 25.2 & 8.99 & 11.5 & 10.4 & 15 & 7.5 & 22.9 & 7 \\
\hline 3900 & 3500 & 1400 & 1380 & 1330 & 1630 & 4460 & 2180 & 2800 & 4100 & 4300 & 4600 & 1200 \\
\hline 253 & 127 & 138 & 238 & 244 & 277 & 167 & 114 & 211 & 214 & 164 & 235 & 78.2 \\
\hline$<5$ & $<5$ & $<5$ & $<5$ & $<5$ & $<5$ & $<5$ & $<5$ & $<5$ & $<5$ & $<5$ & $<5$ & $<5$ \\
\hline
\end{tabular}


Appendix I. (cont.)

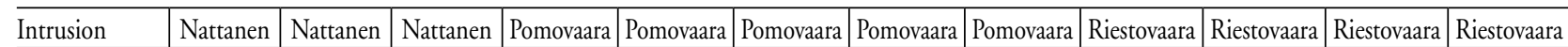
\begin{tabular}{l|l|l|l|l|l|l|l|l|l|l|l|l|}
\hline Sample & 92009679 & 92009683 & 92009691 & 92009552 & 92009555 & 92009559 & 92009561 & 92009629 & 92009672 & 92009569 & 92009705 & 92009544 \\
\hline
\end{tabular}

\begin{tabular}{|c|c|c|c|c|c|c|c|c|c|c|c|c|}
\hline & & & & & & & & & & & & \\
\hline Na_511p ppm & 537 & 496 & 564 & 521 & 626 & 636 & 477 & 561 & 433 & 519 & 713 & 488 \\
\hline Ni_511p ppm & $<3$ & $<3$ & 11.4 & 5.38 & $<3$ & 6.1 & 7.25 & 3.76 & 3.14 & 4.84 & $<3$ & 5.57 \\
\hline P_511p ppm & 81.3 & 72.9 & 69.6 & 225 & $<50$ & 424 & 549 & 70 & 130 & 177 & $<50$ & 469 \\
\hline S_511p ppm & $<20$ & $<20$ & $<20$ & $<20$ & $<20$ & 24.9 & 23.5 & $<20$ & $<20$ & $<20$ & $<20$ & 155 \\
\hline Sc_511p ppm & 2.62 & 3.04 & 2.42 & 1.79 & 1.41 & 2.95 & 4.45 & 1.46 & 2.23 & 2.23 & 1.97 & 2.82 \\
\hline Sr_511p ppm & 1.88 & 2.4 & 2.46 & 7.32 & 2.29 & 7.66 & 5.62 & 2.56 & 4.19 & 4.3 & $<1$ & 6.46 \\
\hline Ti_511p ppm & 160 & 351 & 391 & 638 & 227 & 1790 & 1680 & 328 & 730 & 1470 & 61.1 & 1620 \\
\hline V_511p ppm & $<1$ & 3.23 & 4.14 & 11.8 & $<1$ & 23 & 29.2 & 2.92 & 5.13 & 10.8 & $<1$ & 28 \\
\hline Y_511p ppm & 20.7 & 12.5 & 14.1 & 21.7 & 13.8 & 16.1 & 23.3 & 11.9 & 18.4 & 23.9 & 9.32 & 18.2 \\
\hline Zn_511p ppm & 7.62 & 5.19 & 14.6 & 31.7 & 8.03 & 39.6 & 65.8 & 11.5 & 20.4 & 9.29 & 8.22 & 25.5 \\
\hline Ag_511u ppm & $<0.1$ & $<0.1$ & $<0.1$ & $<0.1$ & $<0.1$ & $<0.1$ & $<0.1$ & $<0.1$ & $<0.1$ & $<0.1$ & $<0.1$ & $<0.1$ \\
\hline Se_511u ppm & $<0.02$ & $<0.02$ & $<0.02$ & $<0.02$ & $<0.02$ & $<0.02$ & $<0.02$ & $<0.02$ & $<0.02$ & $<0.02$ & $<0.02$ & $<0.02$ \\
\hline Au_521u ppb & $<0.5$ & $<0.5$ & $<0.5$ & $<0.5$ & $<0.5$ & $<0.5$ & $<0.5$ & $<0.5$ & $<0.5$ & $<0.5$ & $<0.5$ & $<0.5$ \\
\hline Pd_521u ppb & $<5$ & $<5$ & $<5$ & $<5$ & $<5$ & $<5$ & $<5$ & $<5$ & $<5$ & $<5$ & $<5$ & $<5$ \\
\hline Te_521u ppb & $<10$ & $<10$ & $<10$ & $<10$ & $<10$ & $<10$ & $<10$ & $<10$ & $<10$ & $<10$ & $<10$ & $<10$ \\
\hline F_707i \% & 0.186 & 0.109 & 0.108 & 0.073 & 0.024 & 0.072 & 0.083 & 0.045 & 0.103 & 0.057 & 0.09 & 0.14 \\
\hline C_8111 tot $\%$ & $<0.01$ & 0.013 & $<0.01$ & 0.012 & 0.012 & 0.016 & 0.024 & 0.012 & $<0.01$ & 0.014 & $<0.01$ & 0.015 \\
\hline CO2_8161\% & $<0.18$ & $<0.18$ & $<0.18$ & $<0.18$ & $<0.18$ & $<0.18$ & $<0.18$ & $<0.18$ & $<0.18$ & $<0.18$ & $<0.18$ & $<0.18$ \\
\hline Cgraf_8161\% & $<0.05$ & $<0.05$ & $<0.05$ & $<0.05$ & $<0.05$ & $<0.05$ & $<0.05$ & $<0.05$ & $<0.05$ & $<0.05$ & $<0.05$ & $<0.05$ \\
\hline Ce_308m ppm & 199 & 159 & 146 & 110 & 11 & 146 & 145 & 79.1 & 154 & 243 & 37.6 & 196 \\
\hline Lu_308m ppm & 0.319 & 0.25 & 0.299 & 0.367 & 0.223 & 0.235 & 0.36 & 0.26 & 0.273 & 0.245 & 0.268 & 0.317 \\
\hline $\mathrm{Nb \_ 308 \textrm {m } \mathrm { ppm }}$ & 27.6 & 16.2 & 13.5 & 16 & 10.7 & 14 & 29.6 & 14.6 & 16.8 & 18.6 & 22.8 & 14.3 \\
\hline Nd_308m ppm & 72.9 & 54.3 & 49.8 & 37.9 & 5.5 & 44.6 & 50.6 & 21.2 & 50.2 & 82.4 & 9.19 & 64.7 \\
\hline Pr_308m ppm & 22.9 & 17.2 & 15 & 11.9 & 1.46 & 13.5 & 16 & 7.63 & 16.5 & 27 & 3.52 & 21.2 \\
\hline Rb_308m ppm & 157 & 171 & 171 & 187 & 203 & 152 & 229 & 266 & 184 & 179 & 317 & 137 \\
\hline Sc_308m ppm & 4.77 & 4.8 & 3.48 & 3.23 & 2.06 & 4.11 & 6.83 & 1.59 & 2.71 & 1.48 & 3.89 & 4.03 \\
\hline Sm_308m ppm & 10.2 & 7.29 & 7.05 & 6.28 & 1.81 & 6.26 & 7.35 & 2.78 & 7.12 & 10.7 & 1.19 & 8.19 \\
\hline Ta_308m ppm & 0.83 & 0.813 & 0.847 & 1.51 & 1.84 & 0.946 & 1.76 & 1.11 & 1.06 & 1.04 & 1.1 & 0.965 \\
\hline Tb_308m ppm & 0.936 & 0.663 & 0.731 & 0.827 & 0.239 & 0.654 & 0.86 & 0.326 & 0.743 & 1.08 & 0.15 & 0.925 \\
\hline Th_308m ppm & 27.2 & 28.1 & 23.3 & 21.2 & 47.9 & 23.9 & 50.9 & 46.7 & 25.9 & 23.9 & 32.3 & 26.3 \\
\hline Tm_308m ppm & 0.349 & 0.255 & 0.267 & 0.339 & 0.213 & 0.269 & 0.392 & 0.191 & 0.276 & 0.38 & 0.174 & 0.379 \\
\hline U_308m ppm & 3.1 & 2.94 & 2.43 & 3.18 & 11.8 & 2.74 & 4.93 & 8.6 & 3.13 & 2.12 & 12.6 & 2.16 \\
\hline V_308m ppm & 1.79 & 4.01 & 6.35 & 11.7 & 1.13 & 18.9 & 26.2 & 4.32 & 5.14 & 7.97 & 1.61 & 25.5 \\
\hline Y_308m ppm & 28.4 & 20.1 & 22 & 28.7 & 14.4 & 17.5 & 27.4 & 13.9 & 22.3 & 31 & 10.7 & 28.2 \\
\hline Yb_308mppm & 2.2 & 1.67 & 1.94 & 2.37 & 1.39 & 1.83 & 2.6 & 1.62 & 1.84 & 2.33 & 1.55 & 1.87 \\
\hline $\mathrm{Zr} \_308 \mathrm{~m} \mathrm{ppm}$ & 247 & 185 & 161 & 168 & 158 & 163 & 377 & 103 & 192 & 271 & 69.3 & 242 \\
\hline
\end{tabular}




\begin{tabular}{|c|c|c|c|c|c|c|c|c|c|c|c|c|}
\hline Tepasto & Vainospää & Vainospää & \begin{tabular}{|l|} 
Vainospää \\
\end{tabular} & Vainospää & \begin{tabular}{|l|} 
Vainospää \\
\end{tabular} & Vainospää & \begin{tabular}{|l|} 
Vainospää \\
\end{tabular} & Vainospää & Vainospää & Vainospää & Vainospää & Vainospää \\
\hline 93001676 & 95001306 & 95001302 & 91011354 & 91011362 & 91011365 & 91011367 & 91011369 & 95001281 & 95001282 & 95001283 & 95001307 & 95001308 \\
\hline 400 & 400 & 500 & 587 & 647 & \begin{tabular}{|l|}
654 \\
\end{tabular} & 630 & 824 & 500 & 600 & 500 & 500 & 500 \\
\hline 5 & 5 & 3.8 & 3.61 & 4.2 & 4.15 & 4.59 & 4.83 & 4 & 5.8 & 8.3 & 6.7 & 3.9 \\
\hline 594 & 334 & 120 & 168 & 129 & 168 & 214 & 237 & 189 & 425 & 631 & 566 & 104 \\
\hline$<30$ & $<30$ & $<30$ & $<30$ & $<30$ & $<30$ & $<30$ & $<30$ & $<30$ & $<30$ & $<30$ & $<30$ & $<30$ \\
\hline 46 & $<20$ & $<20$ & $<20$ & $<20$ & $<20$ & $<20$ & $<20$ & $<20$ & $<20$ & 318 & 134 & $<20$ \\
\hline 2.8 & 1.7 & 1.6 & 1.28 & 1.22 & 2.19 & 1.41 & 1.14 & 1.8 & 3.5 & 1.7 & 4.3 & 1.1 \\
\hline 7.1 & 5.7 & 6.4 & 6.24 & 5.24 & 5.38 & 4.96 & 5.91 & 7.4 & 15.1 & 30.5 & 15.4 & 10.5 \\
\hline 26 & 45 & 51 & 52.9 & 47.6 & 51.7 & 55.9 & 15.6 & 44 & 42 & 46 & 66 & 27 \\
\hline 1760 & 384 & 565 & 647 & 549 & 780 & 179 & 801 & 728 & 1410 & 2250 & 1730 & 462 \\
\hline 25.9 & 17.5 & 5.1 & 6.36 & 5.61 & 7.11 & 5.72 & 10.5 & 10.5 & 23.7 & 27.6 & 29 & 14.2 \\
\hline 11.2 & 8.5 & 6.8 & 11.5 & 6.71 & 13.6 & 7.6 & 3.38 & 7.4 & 12.5 & 7.5 & 13.1 & 2.2 \\
\hline 36 & 19.2 & 27.6 & 39.5 & 30.9 & 38.4 & 20.7 & 39.4 & 25.7 & 42.5 & 17.5 & 69.1 & 11.8 \\
\hline$<0.1$ & 0.18 & $<0.1$ & $<0.1$ & $<0.1$ & 0.211 & $<0.1$ & $<0.1$ & $<0.1$ & 0.44 & $<0.1$ & 0.4 & $<0.1$ \\
\hline 0.9 & 0.6 & 0.6 & 0.255 & 0.359 & 0.321 & $<0.2$ & 0.311 & 0.8 & 0.9 & 0.9 & 0.7 & 0.5 \\
\hline 0.02 & $<0.01$ & $<0.01$ & 0.0826 & $<0.01$ & $<0.01$ & 0.0252 & 0.033 & $<0.01$ & 0.02 & 0.02 & $<0.01$ & $<0.01$ \\
\hline$<0.03$ & $<0.03$ & $<0.03$ & 0.0413 & $<0.03$ & 0.0421 & $<0.03$ & $<0.03$ & $<0.03$ & $<0.03$ & $<0.03$ & $<0.03$ & $<0.03$ \\
\hline$<0.02$ & $<0.02$ & $<0.02$ & $<0.02$ & $<0.02$ & $<0.02$ & $<0.02$ & $<0.02$ & $<0.02$ & $<0.02$ & $<0.02$ & $<0.02$ & $<0.02$ \\
\hline$<0.5$ & $<0.5$ & $<0.5$ & $<0.5$ & $<0.5$ & $<0.5$ & $<0.5$ & $<0.5$ & $<0.5$ & $<0.5$ & $<0.5$ & $<0.5$ & $<0.5$ \\
\hline$<5$ & $<5$ & $<5$ & $<5$ & $<5$ & $<5$ & $<5$ & $<5$ & $<5$ & $<5$ & $<5$ & $<5$ & $<5$ \\
\hline$<10$ & $<10$ & $<10$ & $<10$ & $<10$ & $<10$ & $<10$ & $<10$ & $<10$ & $<10$ & $<10$ & $<10$ & $<10$ \\
\hline 0.04 & 0.05 & 0.04 & 0.04 & $<0.02$ & $<0.02$ & $<0.02$ & $<0.02$ & 0.05 & 0.13 & 0.13 & 0.14 & 0.04 \\
\hline 0.02 & $<0.01$ & $<0.01$ & $<0.01$ & $<0.01$ & $<0.01$ & $<0.01$ & $<0.01$ & $<0.01$ & $<0.01$ & $<0.01$ & $<0.01$ & 0.02 \\
\hline$<0.18$ & $<0.18$ & $<0.18$ & $<0.18$ & $<0.18$ & $<0.18$ & $<0.18$ & $<0.18$ & $<0.18$ & $<0.18$ & $<0.18$ & $<0.18$ & $<0.18$ \\
\hline$<0.05$ & $<0.05$ & $<0.05$ & $<0.05$ & $<0.05$ & $<0.05$ & $<0.05$ & $<0.05$ & $<0.05$ & $<0.05$ & $<0.05$ & $<0.05$ & $<0.05$ \\
\hline 84.5 & 143 & 71.1 & 111 & 69.4 & 116 & 147 & 47.4 & 98.5 & 196 & 204 & 299 & 71.1 \\
\hline 2.57 & 2.16 & 1.39 & 2.63 & 1.53 & 2.74 & 2.11 & 0.942 & 1.74 & 2.81 & 1.71 & 3.26 & 0.65 \\
\hline 1.15 & 0.99 & 0.6 & 1.37 & 0.808 & 1.34 & 1.05 & 0.361 & 0.73 & 1.3 & 0.7 & 1.23 & 0.2 \\
\hline 0.69 & 0.85 & 0.53 & 0.517 & 0.376 & 0.545 & 0.464 & 0.402 & 0.58 & 0.91 & 1.2 & 1.12 & 0.45 \\
\hline 3.3 & 3.97 & 2.99 & 3.99 & 2.68 & 4.43 & 3.78 & 1.72 & 3.56 & 5.49 & 4.43 & 7.64 & 1.39 \\
\hline 5.29 & 5.68 & 3.34 & 4.53 & 3.97 & 4.45 & 4.89 & 3.57 & 4.43 & 5.99 & 5.61 & 10 & 3.61 \\
\hline 0.48 & 0.37 & 0.24 & 0.473 & 0.314 & 0.562 & 0.413 & 0.132 & 0.27 & 0.5 & 0.28 & 0.56 & $<0.1$ \\
\hline 50.1 & 79.4 & 42.8 & 59.6 & 39.3 & 65.8 & 83.2 & 26.6 & 57.3 & 112 & 123 & 173 & 44.3 \\
\hline 0.2 & 0.14 & $<0.1$ & 0.201 & $<0.1$ & 0.2 & 0.163 & $<0.1$ & $<0.1$ & 0.15 & $<0.1$ & 0.13 & $<0.1$ \\
\hline 10.4 & 11.5 & 8.75 & 12.6 & 8.32 & 14.4 & 11.9 & 3.64 & 10 & 17.3 & 13 & 27.5 & 3.1 \\
\hline 29.1 & 48.3 & 23.1 & 35.6 & 23.9 & 35.4 & 45.1 & 14.6 & 32.2 & 61.3 & 61.6 & 89.9 & 20.3 \\
\hline 8.79 & 15.4 & 7.15 & 11.3 & 7.43 & 11.5 & 14.6 & 4.52 & 10.2 & 19.5 & 20.4 & 29.7 & 7.06 \\
\hline 146 & 155 & 187 & 270 & 256 & 258 & 208 & 120 & 237 & 185 & 156 & 239 & 144 \\
\hline 2.98 & 2.51 & 1.8 & 2.99 & 2.53 & 2.96 & 3.17 & 2.12 & 3.46 & 5.28 & 3.54 & 4.34 & 1.46 \\
\hline 4.34 & 6.20 & 3.61 & 5.21 & 3.50 & 5.44 & 5.59 & 2.24 & 4.45 & 7.66 & 6.7 & 10.3 & 2.19 \\
\hline 1.01 & 0.89 & 0.49 & 1.32 & 0.625 & 1.19 & 0.714 & 0.229 & 0.48 & 1.72 & 0.89 & 1.35 & 0.24 \\
\hline 0.49 & 0.53 & 0.36 & 0.521 & 0.298 & 0.556 & 0.526 & 0.198 & 0.44 & 0.69 & 0.49 & 0.88 & 0.18 \\
\hline 20.5 & 31.9 & 39.4 & 41.3 & 40.4 & 42.6 & 51.6 & 10.4 & 36 & 29.8 & 36 & 45 & 19.7 \\
\hline 0.17 & 0.15 & $<0.1$ & 0.205 & $<0.1$ & 0.181 & 0.174 & $<0.1$ & $<0.1$ & 0.2 & $<0.1$ & 0.15 & $<0.1$ \\
\hline 2.43 & 4.57 & 12.3 & 6.83 & 6.26 & 5.74 & 7.64 & 1.79 & 6.39 & 3.15 & 10.6 & 1.78 & 1.91 \\
\hline 23.4 & 19.5 & 5.47 & 7.73 & 7.06 & 8.38 & 10 & 12.1 & 12.1 & 23.1 & 29.4 & 26.7 & 13.1 \\
\hline 15.1 & 10.6 & 7.48 & 16 & 8.64 & 16.8 & 11.8 & 4.18 & 9.09 & 16.2 & 9.48 & 15.8 & 2.9 \\
\hline 1.3 & 0.95 & 0.47 & 1.25 & 0.661 & 1.43 & 1.01 & 0.311 & 0.56 & 1.2 & 0.62 & 0.99 & 0.25 \\
\hline 209 & 203 & 113 & 146 & 121 & 152 & 170 & 143 & 161 & 257 & 252 & 383 & 100 \\
\hline
\end{tabular}




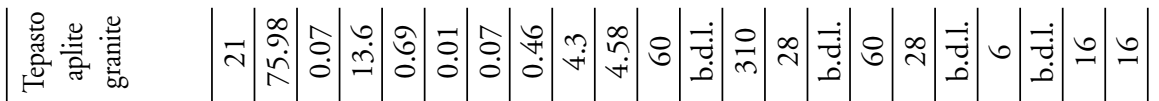

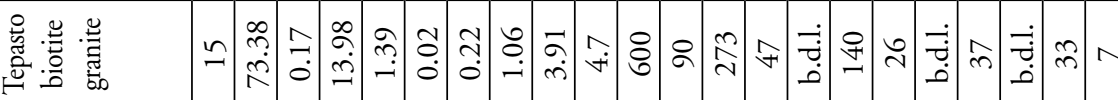

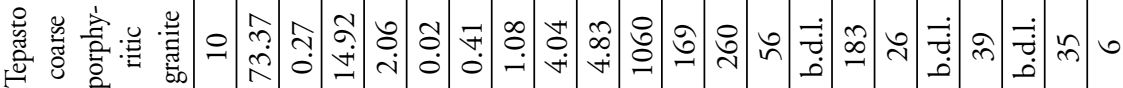

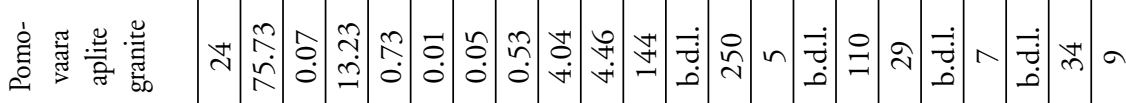

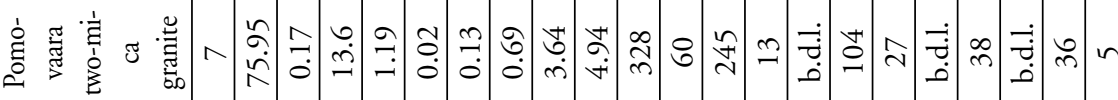

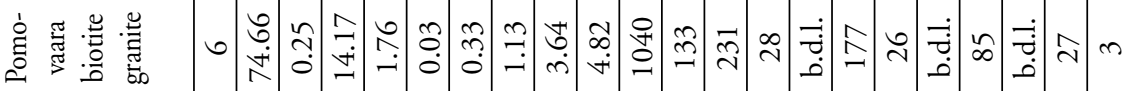

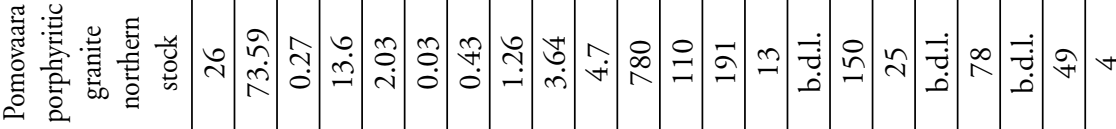

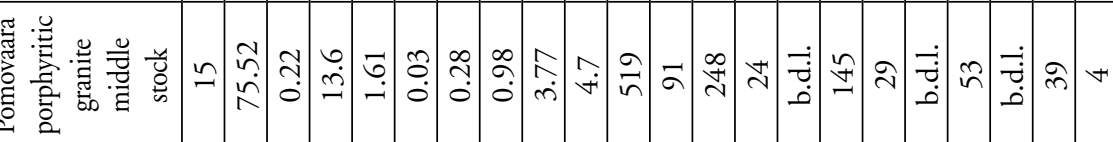

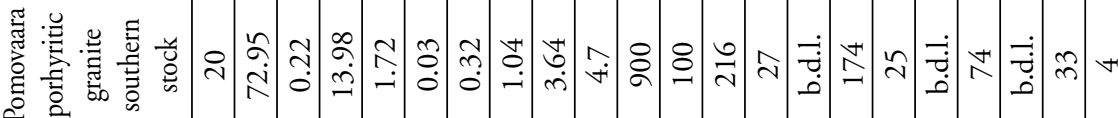

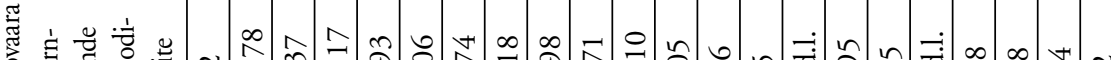

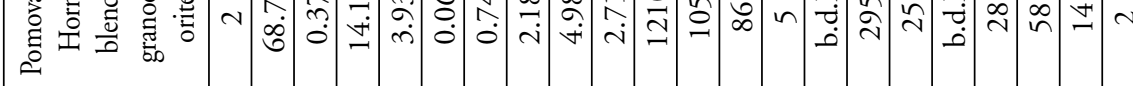

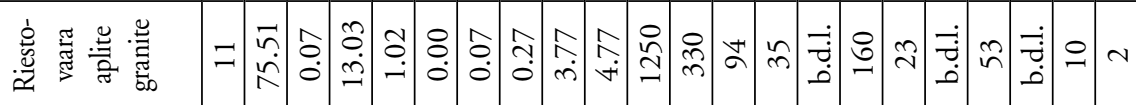

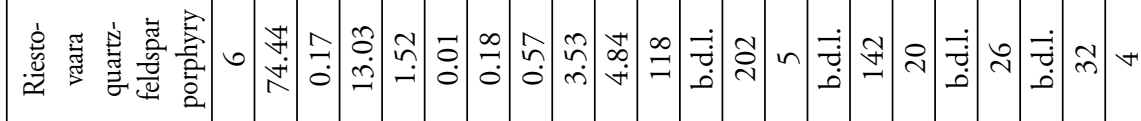

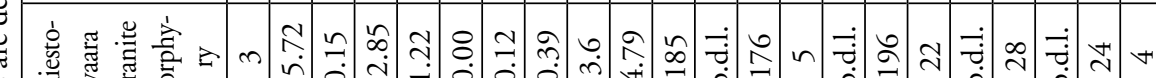

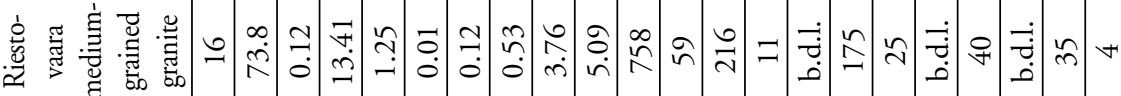
$\stackrel{\infty}{\rightleftharpoons}$

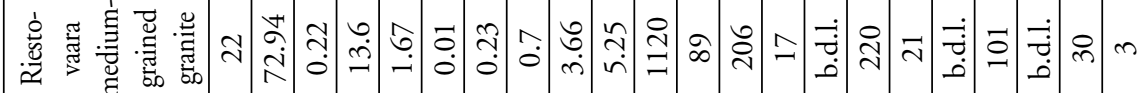
苛

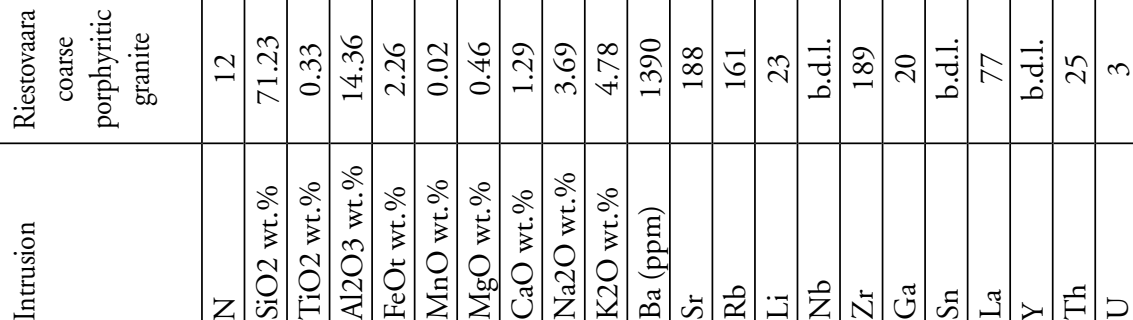

